\title{
ANTITRUST AND HOSPITAL PEER REVIEW
}

\author{
James F. Blumstein* and Frank A. Sloan $\dagger$
}

\section{TABLE OF Contents}

I. Introduction $\ldots \ldots \ldots \ldots \ldots \ldots \ldots \ldots \ldots \ldots \ldots \ldots \ldots \ldots \ldots \ldots \ldots, \quad 8$

II. Institutionalized Peer Review: Rationale, Context, and

Implications $\ldots \ldots \ldots \ldots \ldots \ldots \ldots \ldots \ldots \ldots \ldots \ldots, 10$

A. What is Hospital Peer Review .................... 10

B. Rationale for Medical Staff Peer Review ................ 12

C. Risks of Peer Review by the Hospital Medical Staff......... 14

1. Historical Perspective ...................... 15

2. Economic Models of the Hospital ................ 18

3. Sociological and Organizational Perspectives ......... 22

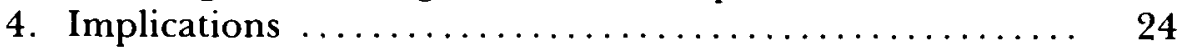

III. Antitrust Doctrine: An Overview of the General Issues ......... 25

A. The Nature and Scope of Permissible Justificiations ....... 28

B. Potential Immunity from Antitrust Liability ........... 32

1. The Health Care Quality Improvement Act ......... $\quad 32$

2. State Action Immunity ...................... 34

IV. Application of Antitrust Doctrine to Hospital Peer-Review Activity 37

A. The Capacity to Conspire: A Threshold Issue ........... 39

B. Substantive Doctrine ......................... 53

1. In General: Per Se vs. Rule of Reason Analysis ....... 53

2. Hospital Peer Review as a Vertical Restraint: The Vertical/Horizontal Distinction ................ 56

3. Hospital Peer Review as a Horizontal Restraint: The General Case ............................... 65

4. Hospital Peer Review as a Horizontal Restraint: Specific Circumstances ............................. 68

a. The Case of Physician Cartel Behavior ........... 69

b. The Case of Demonstrated Market Power......... 72

* Professor of Law, Vanderbilt Law School; Senior Fellow, Vanderbilt Institute for Public Policy Studies; John M. Olin Visiting Professor of Law, University of Pennsylvania Law School (Spring 1989).

$\dagger$ Centennial Professor of Economics and Director, Health Policy Center, Institute for Public Policy Studies, Vanderbilt University.

The authors express their appreciation to the HCA Foundation, which provided support for this project, and to Jennifer Redmond and Paul Wolfteich, Vanderbilt Law School Class of 1989, for their excellent research assistance. The views presented are those of the authors. 
5. The Hospital Privileges Context: The Application of the Rule of Reason .............................. 78

a. The Case of Physician Cartel Behavior Revisited .... 78

i. A Rebuttable Presumption of Invalidity ....... 79

ii Application of the Rebuttable Presumption to Specific Circumstances .....................

iii. The Implications of the Health Care Quality Improvement Act ..................... 82

b. Application of the Rule of Reason: The General Case 86

i. Market Conditions .................. 86

ii. Motivation........................... 87

iii. The Nature of the Challenged Conduct ....... 88

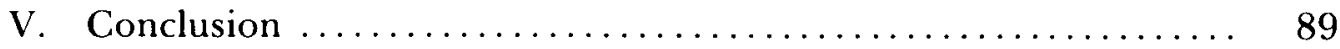

\section{INTRODUCTION}

Mindset and context have a great deal to do with how we perceive conduct. To a skier, the opening of a new ski resort may be a cause for rejoicing; for an environmentalist, the same event may be a cause for disconsolation-the desecration of a wilderness.

In the health policy arena, this phenomenon, this divergence of perspectives, comes forcefully into play as the industry has moved into the current competitive era. ${ }^{1}$ In the regulated environment, cross-subsidies from oligopolistic hospital-pricing practices were routinely applied to favor projects or services deemed worthy by authoritative decisionmakers. Those in control of health care institutions typically used excessive returns in some areas to provide funds for (that is, to subsidize) designated under-financed activities or services-for example, specialized teaching and research programs such as burn centers or neo-natal intensive care units; or worthy purposes such as care for indigent patients. Competitors who chose not to provide the money-losing services were saddled with the pejorative label of "cream skimmers." The charge-if such it be-was that cream-skimming resulted in a reduced opportunity to provide appropriate support for needed services.

In a competitive environment, the very same conduct is typically characterized quite differently, and more favorably. Cream-skimming behavior is viewed as an example of appropriate market entry by competitors to compete away supra-competitive prices and profits. Indeed, an objective of a competitive approach is the reduction of supra-competitive prices and profits by new entrants into a market. The failure of competitors to enter

1. For a discussion of this issue in the context of the role of health planning in a competitive health care marketplace, see Blumstein, Effective Health Planning in a Competitive Environment, in Cost, Quality, and Access in Health Care: New Roles for Health Planning in a Competitive Environment 21 (F. Sloan, J. Blumstein \& J. Perrin eds. 1988). See generally C. Havighurst, Deregulating the Health Care Industry 13-24 (1982). 
markets where supra-competitive prices exist is deemed an illustration of market failure-of artificial (and undesirable) barriers to entry. Public policy should be directed at correcting that market failure. The very type of crosssubsidization deemed worthy by health planners and hospital administrators is regarded critically-as an illegitimate form of "taxation by regulation."2

As antitrust doctrine has begun to play an increased role in the health care industry, ${ }^{3}$ similar examples of cultural dissonance emerge. Hospital industry planners, accustomed to pressures for developing cooperative or regionalized arrangements, face the rude reality that, for antitrust enforcement authorities, such arrangements look very much like illegal anticompetitive activities. Agreements by providers to specialize and not to duplicate facilities or services may appear, through the lens of antitrust, to be a conspiracy to engage in the highly anticompetitive and illegal act of dividing markets. ${ }^{4}$ Techniques once thought by health planners or hospital administrators to be tools of sound planning may, in the context of antitrust, turn out to be viewed as highly suspect, illegal anticompetitive activities.

This article will focus on the application of antitrust doctrine in one particular facet of the health care industry-institutionalized peer-review activities, particularly in hospitals. It will demonstrate the antitrust problems posed by peer review and examine both how antitrust doctrine can accommodate this type of group conduct and how traditional peer-review activity must, in turn, accommodate itself to the requirements of antitrust doctrine. One thing is clear. As far as courts and enforcement authorities are concerned, antitrust doctrine is, in general, fully applicable to the health care industry. ${ }^{5}$ There may be doctrinal adaptations, as there often are when traditional antitrust doctrines are applied in new or unfamiliar contexts. ${ }^{6}$ And there has been recent legislative activity to offset some potentially harmful effects of antitrust law on peer review. ${ }^{7}$ At present, the intellectual struggle has been to get the players on both sides-antitrust experts and health care specialists-to become conversant with each other's weltanschaung and with the consequences of the application of antitrust principles to the health care industry. As we shall discover, the relationship of antitrust and health care at present is past the stage of a blind date but not yet to the state of reliable and stable matrimonial bliss.

2. See Posner, Taxation by Regulation, 2 Bell J. Econ. \& Management Sci. 22 (1971).

3. See, e.g., Patrick v. Burget, 108 S. Ct. 1658 (1988); FTC v. Indiana Fed'n of Dentists, 476 U.S. 447 (1986); Jefferson Parish Hosp. Dist. No. 2 v. Hyde, 466 U.S. 2 (1984); Arizona v. Maricopa County Medical Soc'y, 457 U.S. 332 (1982); National Gerimedical Hosp. \& Geronotology Center v. Bluc Cross, 452 U.S. 378 (1981).

4. See, e.g., United States v. Topco Assocs., Inc., 405 U.S. 596 (1972).

5. See, e.g., FTC v. Indiana Fed'n of Dentists, 476 U.S. 447 (1986).

6. Id.

7. See Health Care Quality Improvement Act of 1986, 42 U.S.C. \$§11101, $11111-11152$ (Supp. 1988); see generally Note. The Health Care Quality Improvement Act of 1986: Will Physicians Find Peer Review More Inviting?, 74 VA. L. REv. 1115 (1988). 


\section{Institutionalized Peer Review: Rationale, CONTEXT, AND IMPLICATIONS}

\section{A. What is Hospital Peer Review}

The current system of hospital-based medical staff peer review has evolved over a century or more and has changed as the relationships between physicians and hospitals have changed. During most of the nineteenth century, hospitals were almshouses for the poor who used such facilities to recuperate from long-term illnesses. At one time, hospital patients were "inmates." 8 The nonpoor were treated by physicians in their homes. Under such circumstances, physician participation in the hospital was limited.

Publication of Lister's work on antisepsis in 1867 was a milestone in that improved infection control made it possible to perform surgery in hospitals on a widespread basis. Emphasis on surgery and treatment of acute illnesses in general toward the end of the century led to a major reorientation of hospitals. The indigent, long-term care patient was no longer the "modal" patient in most hospitals. Physicians began to have a financial stake in gaining access to hospitals. As physicians' involvement in hospitals became more common, they not only increasingly asserted their economic independence, but, as well, began to assert control over professional matters as they arose in these institutions. ${ }^{9}$ In 1919, the American College of Surgeons established as a prerequisite for College approval of the hospital that physicians affiliated with a hospital organize into a medical staff. ${ }^{10}$ Also in 1919, the American Medical Association's Council on Medical Education set minimum standards for hospital internships. ${ }^{11}$

At about the same time, physician organizations, most notably the American College of Surgeons, mounted campaigns to improve the standard of care in hospitals by imposing minimum requirements on recordkeeping, the performance of autopsies, and various aspects of medical staff organization. ${ }^{12}$ In 1952, the Joint Commission on Accreditation of Hospitals ("JCAH") 13 was formed by the American College of Surgeons in conjunction with the American Medical Association, the American Hospital Association, and the American College of Physicians. Since its formation, the JCAH has performed the hospital accreditation function. Included in the JCAH standards for accreditation are requirements that the physicians at a hospital

8. C. Rosenberg, The Care of Strangers: The Rise of America's Hospital System 17 (1987); Stevens, A Poor Sort of Memory: Voluntary Hospitals and Government before the Depression, 60 Milbank Memorial Fund Q.: Health \& Soc'y 551 (1982).

9. P. Starr, The Social Transformation of American Medicine 164-69 (1982); Perrow, The Analysis of Goals in Complex Organizations, 26 AM. Soc. REv. 858 (1961).

10. See Starr, supra note 9 .

11. Id

12. Id.

13. The Joint Commission on Accreditation of Hospitals ("JCAH") is now the Joint Commission on Accreditation of Healthcare Organizations ("JCAHO"). We will continue to use the older nomenclature. See infra note 249. 
organize as an autonomous medical staff. JCAH standards are taken seriously and have been extremely influential because accreditation is a matter of considerable importance to hospitals. Several states mandate JCAH accreditation, and others allow private accreditation to substitute for state licensure. Under certain circumstances, Medicare may regard JCAHaccredited hospitals as automatically eligible for Medicare reimbursement. ${ }^{14}$

The JCAH over time has refined its standards for hospital medical staff. In the current version of the standards, the medical staff of a hospital is charged with the collective responsibility of establishing uniform criteria for evaluating applicants for membership in hospital medical staff and for continuing staff membership. ${ }^{15}$ The criteria that the hospital shall establish are ostensibly designed to assure that patients will be provided quality care. Judgment as to the quality of individual physicians may be made on the basis of current licensure, relevant training, experience, current competence, and health status. The JCAH recommends that hospitals collect such information from a physician applicant as the following: involvement in any professional liability action; previously successful or pending challenges to any licensure or registration; and loss of staff privileges at any other hospital. ${ }^{16}$ In evaluating an application for membership, the medical staff may consider "other reasonable qualifications," such as the ability of the hospital to provide facilities and supportive services for the applicant and his patients, patient care needs for additional staff members with the applicant's skill and training, evidence that the applicant has adequate professional liability insurance, and the geographic location of the applicant. ${ }^{17}$ In theory, the hospital's medical staff only makes recommendations on appointments, whereas the governing body of the hospital makes the final decisions on each application. In practice, most observers have concluded that under normal circumstances the actual control of privileges decisions typically rests with-that is, is delegated to-the medical staff. ${ }^{18}$ Appointment to the medical staff is to be made for a period of no more than two years. ${ }^{19}$

Hospital accreditation requirements of the JCAH as they apply to medical staff at least formally imply that hospital peer review must be conducted in a rigorous manner. The currently applicable Medical Staff Chapter of the JCAH Accreditation Manual contains specific requirements pertinent to the hospital's quality assurance program. The department chairman, or medical staff in a hospital with a nondepartmentalized medical staff, is responsible for assuring implementation of a process for monitoring the quality and

14. See generally Cospito v. Heckler, 742 F.2d 72 (3d (iir. 1984).

15. Joint Commission on ACCREdTation of Hospilil.s, AMH 88/ACCREditation Manual for Hospitals 112 (1987).

16. Id.

17. Id.

18. The governing board is seen as a "double dic.k" (MI lle objectivity of medical staff in making hospital appointments. See M. Roemer \& J liktrimin. Docionss in Hospitals: Medical Staff Organization and Hospital Performancit 4.4 (1971).

19. Id. at 113 . 
appropriateness of care delivered by physicians at the hospital. ${ }^{20}$ Medical staff monitoring is to include routine collection of information about aspects of patient care provided and about clinical performance of members. ${ }^{21}$ Surgical case review, including case-specific review on a sample of cases, is to be conducted routinely. ${ }^{22}$

The JCAH standards clearly call for regular review of quality and appropriateness of care by the hospital's medical staff. Unfortunately, there is no "hard" empirical evidence on the extent to which hospitals have actually implemented these standards and on the precise approaches actually used. ${ }^{23}$

\section{B. Rationale for Medical Staff Peer Review}

One traditional justification for hospital-based peer review by the medical staff relies on the asserted existence of asymmetric information between buyers and sellers of medical care. Buyers presumably are ill-informed about the services they purchase. ${ }^{24}$ Advertising of quality and price in this arena is inappropriate, so the argument goes, because consumers are easily misled. Instead of improving the flow of information, which according to this viewpoint is excessively costly and probably unworkable, hospitals should require various types of regulatory protections for patients. Since the medical field is so specialized, only physicians can protect patients from poor-quality medical care. Licensure and even certification-other mechanisms to provide consumer protection-are presumably too blunt to provide sufficient protection. ${ }^{25}$ Third party payers, which might serve as purchasing agents for consumers, have traditionally been passive and have not instituted sufficiently strong and effective quality assurance mechanisms. ${ }^{26}$ Thus, some believe that external quality-of-care review is needed.

As a group, those who espouse this set of justifications for professional self-regulation are suspicious of and typically oppose promoting a competitive health care marketplace as an object of health care policy. They see competition and health care quality assurance as conflicting objectives. They tend to denigrate the importance of consumer choice and assert that facilitating patient decisionmaking, either directly or through information

20. Id. at 125 .

21. Id.

22. Id. at 126 .

23. The JCAH recently conducted a survey to assess the status of board-management medical staff relationships in hospitals nationally. Dreuth, AHA Update: Defining Limits of Medical Staff SelfGovernance, 40 Truste 15 (Dec. 1987).

24. Arrow, Lncertainty and the Welfare Economics of Medical Care, 53 Am. Econ. Rev. 941, 951 (1963); Pauly, Is Medical Care Different? in Competition in the Health Care Sector: Past, Present, AND Future 11, 14-23 (W. Greenberg ed. 1978).

25. For critical reviews of purposes and effects of physician licensure, see J. BERLANT, Profession and Monopoly: A Study of Medicine in the United States and Great Britain 177 252 (1975), and P. Feldstein, Health Associations and the Demand for legislation: The Political. Economy of Health 58 (1977).

26. This criticism of the traditional health insurance system has been frequently stated. See, e.g., M. Pauly, Doctors and Their Workshops: Economic Models of Physician Behavior 17 (1980). 
intermediaries, is ineffective. In short, this view is somewhat paternalistic in nature. ${ }^{27}$

There are three other rationales for peer review that are more philosophically compatible with a procompetitive analytical framework, which the antitrust laws mandate. One starts from the same premise, namely that consumer information is deficient. Under this view, however, peer reviewers, given their knowledge, can assemble and disseminate information to consumers as their information intermediaries. In this role, which is analogous to the function performed by Consumer Reports, the peer reviewers would not necessarily be members of the hospital medical staff; rather they could well be external to the hospital. Their function would be to perfect the market by improving the ability of patients and their agents to make informed decisions. ${ }^{28}$ At least up to now, such peer review has been opposed by many in the medical profession who have little faith in consumer judgments even if so informed by an outside group. Recent opposition to the publication of hospital-specific mortality rates is an example of that type of opposition. ${ }^{29}$

A second justification for peer review is based on the concept of moral hazard. In the presence of nearly complete insurance, patients are likely to demand care up to the point at which the value of the marginal unit is nearly zero. Because of insurance, the value of the marginal unit to the consumer may be far less than the marginal cost of producing it. ${ }^{30}$ That is, the social cost of providing a service may substantially exceed the individual cost confronted by a particular patient. ${ }^{31}$

Under the fee-for-service system, which still predominates, the patient's physician, in the absence of oversight, has no financial incentive to say no to the patient. ${ }^{32}$ And, as in the case of most professionals, a physician is likely to favor any diagnostic procedure or treatment regimen that has any positive benefit for his patient. The traditional professional ethic has been that expense should be of little or no concern when life or health is at stake. Therefore, because of the disjunction between the marginal cost to the patient and the actual marginal cost of providing a service, some would argue

27. The view that markets cannot function adequately in health has often been expressed. See, e.g., Gross, The Need for Health Plaming, in Regulating Health Facilities Construction $17-31$ (C. Havighurst ed. 1974). The phrase "paternalistic in nature" is ours.

28. Health planners, for example, could provide information on characteristics of hospitalsprice, quality, availability of facilities and services in the areas they serve. This idea is discussed in depth by James Blumstein and Randall Bovbjerg in a recent book on health planning in a competitive environment. See Blumstein, supra note 1; Bovbjerg, New Directions for Health Planning, in Cost, Quality, and Equity in Health Care: New Roles for Health Planning in a Competitive Environment 206 (F. Sloan, J. Blumstein \& J. Perrin eds. 1988).

29. James, Controversy Mounts Over Efforts to Measure Quality of Health Care, Wall St. J., Dec. 17. 1987, at 33 , col. 4 .

30. J. Newhouse, The Economics of Medical Care 98-100 (1978).

31. Pauly, The Economics of Moral Hazard: Comment, 58 Am. Econ. Rev. 531 (1968).

32. This point has been discussed by a number of authors. See, e.g., Monsma, Marginal Revenue and the Demand for Physicians' Senvices, in EmpIRICal. Studies in Health Economics 145 (H. Klarman ed. 1970). Under the fee-for-service system, the provider is paid extra for each additional service he provides. Under capitation, by contrast, the provider is paid a fixed amount for treating the patient for a certain time period. The costs of extra treatment accrue to the provider. 
that there must be some external source of regulatory oversight designed to review and constrain utilization of services. ${ }^{33}$ There is, of course, room for suspicion about whether a hospital's staff would have any additional incentive to say "no" either, particularly when the participants have an ongoing relationship in which peer review can be a double-edged sword. This type of utilization review is more effectively conducted as "demand-side" peer review, that is by a group outside the hospital answerable to the payer itself. Moreover, in the face of increasing prepayment arrangements, hospital management has a powerful incentive to develop a system of utilization review that is responsive to the hospital's institutional need to stay competitive and live within its means.

A third argument for hospital-based or "supply-side" peer review is much stronger than the moral hazard position. If hospitals are to compete on the basis of quality and quality-adjusted price, from a management perspective they must have the internal capacity to monitor quality. Potential hospital liability for medical malpractice furnishes institutions with an additional incentive to have the capacity to monitor quality. Such internal qualitycontrol capacity is commonplace in other sectors. To safeguard a particular quality standard, a light bulb manufacturer uses workers to monitor the results of other workers, that is, to test for light bulb failure on a sample basis. Quality circles are used to maximize the likelihood that products are manufactured in accordance with demanding quality specifications. Such monitoring (albeit far from perfect) is undertaken, not because the various purchasers of the manufacturer's products are ignorant but rather because they are well-informed. The seller reasons that poor quality will eventually lead to loss of market share. Thus, if anything, the procompetitive case for supply-side peer review is strongest in the case of hospitals acting aggressively in a competitive market to pursue their own institutional goals and in the presence of vigorous review by purchasers or their agents (such as their primary care physicians).

\section{Risks of Peer Review by the Hospital Medical Staff}

The problem with the procompetitive rationale for hospital peer review is that it requires hospitals to act as independent economic entities, acting autonomously in their own self-interest. From the perspective of antitrust policy it is appropriate to nurture that independent role for hospitals, but in implementing antitrust policy, it is also important to take into account the historical role that hospitals-especially non-profit hospitals-have played and the relationship between the hospital and its medical staff. ${ }^{34}$

33. For a discussion of this issue, see Blumstein \& Sloan, Redefining Government 's Role in Health Care: Is a Dose of Competition What the Doctor Should Order?, 34 VAND. L. Rev. 849, 873-75, 881-82 (1981).

34. The most frequently stated justification for hospital-level peer review as opposed to review at another level is that only experts who are at the scene on a continuous basis are qualified to monitor the quality of care provided. Another, more compelling reason, is that hospitals have a self- 
From a quality-of-care perspective and from a utilization-review perspective, the most potentially negative feature of hospital-based, supplyside peer review stems from the fact that the medical staff peer reviewers have an ongoing relationship. Absent egregious circumstances, there is no incentive for an individual medical staff peer reviewer to challenge the conduct of a colleague because, one day, the peer-review shoe may be on the other foot. ${ }^{35}$

From an antitrust perspective, the most potentially negative feature of hospital-based, supply-side peer review stems from the fact that the medical staff peer reviewers are potential competitors with each other and with prospective applicants. The danger lies in the ability of the medical staff to hamper or to exclude other physicians from practicing in the hospital. In particular, expulsion of a doctor from a hospital can have serious, far-reaching and long-term adverse economic/professional consequences; in some cases such expulsion can even be tantamount to excluding a doctor from the profession as a whole. Therefore, in some circumstances, denial of an application for privileges may adversely affect competition. The threat to competition is enhanced by the exercise of concerted power by potential competitors, in common among themselves or in conjunction with the hospital. That type of concerted restraint raises troublesome concerns for the well-being of the competitive marketplace.

Given the historical role of the nonprofit hospital and the relationship between the hospital and its medical staff, there is a genuine and legitimate concern that in some situations, the risks to competition from hospital medical staff peer review and privileges decisions may outweigh the potential benefits to competition. We now turn our attention to consideration of the hospital itself from a variety of perspectives-historical, economic, and sociological.

1. Historical Perspective. Before the twentieth century, hospitals functioned fairly independently of physicians. ${ }^{36}$ Hospitals provided housing for the sick indigent who had no better alternative place to stay. ${ }^{37}$ As they became more actively involved in hospitals, physicians powerfully asserted their professional autonomy. ${ }^{38}$

interest in safeguarding quality. Yet to perform this role effectively, the peer-review process itself must be of high quality.

35. This is not to gainsay that professionals, out of commitment, will participate in peer-review conduct in good faith.

36. C. Rosenberg, supra note 8 , at 25 , notes that during the 1800 's, individual philanthropists supported specific inpatient beds and often retained the right to approve "their" beds' occupants. Lay control over admissions was never absolute since a medical examination was required prior to admission. Yet the very concept of philanthropist interference with the admission process is alien to the notion of the hospital as we know it. The power to admit provides leverage for physicians vis-avis hospitals.

37. See P. Stark, supra note 9.

38. Joint Commission on Accreditation of Hospital.s, supra note 15, at 1164; Rosenberg, supra note 8 , at 271 . 
Physicians vigorously opposed domination by hospitals. Organizations of radiologists and pathologists passed resolutions declaring it undesirable for physicians to work for hospitals for a fixed salary. ${ }^{39}$ The American College of Anesthesiologists found salaried hospital practice to be "unethical." 40 In Iowa and South Carolina, physicians brought suits claiming that state laws prohibiting the corporate practice of medicine were applicable to hospitals which were corporations. Thus, the plaintiffs contended, hospitals should not be allowed to employ physicians on a salaried basis or, more generally, to bill for services provided by physicians. ${ }^{41}$ The authors of Medicare and Medicaid in the mid-1960's accepted the notion that billing for hospital and physicians' services should be done separately, even though lines became blurred in the case of services of hospital-based physicians (primarily radiologists, pathologists, and anesthesiologists) who provide services almost exclusively in hospital settings and whose constant presence is needed for hospitals to function. ${ }^{42}$

Several forces have served to shape and define the relationship between hospitals and their medical staffs although organizational arrangements between hospitals and their doctors have always differed markedly among hospitals. First, hospital accrediting bodies, in particular the JCAH, have established requirements that physicians at a hospital organize as a formal medical staff. Although these requirements have been refined during the last fifty years, they still permit appreciable variation among hospitals in medical staff organization. ${ }^{43}$

Second, the third party payment system has perpetuated separate billing by hospitals and doctors. Blue Cross covers hospital care while its sister organization Blue Shield covers physicians' services irrespective of where the service is delivered. The two organizations have merged, but this merger appears to have had no effect on separate billing. ${ }^{44}$ Medicare pays for

39. P. STARr, supra note 9, at 221 .

40. R. Stevens, American Medicine and the Public Interest 240 n.54 (1971).

41. See 166 J. A.M.A., Iowa Hospital-Doctor Law in Effect, Jan. 25, 1958, at 374-75; M. Roemer \& J. Friedman, supra note 18, at 6-7. But see Hall, Institutional Control of Physician Behavior: Legal Bamiers to Health Care Cost Containment, 137 U. PA. L. Rev. 431, 510 (1988). Professor Hall has called the corporate practice doctrine "puzzling" and "founded on an astounding series of logical fallacies." Id. He observes that "judicial activity in this area has slackened over the last twenty years" and notes that "it is commonly believed that the corporate practice prohibition is dying a quiet death." Id. Professor Hall is "not so optimistic," $i d$., expressing the view that "[p]ast predictions of the demise of physician independence have repeatedly been proven wrong." Id. at 509 . For references to successful invocation of the doctrine, see Rosoff, The Business of Medicine: Problems with the Corporate Practice Doctine, 17 Cumb. L. Rev. 485, 497-99 (1987); Note, The Corporate Practice of Medicine Doctrine: An Anachronism in the Modern Health Care Industry, 40 VAND. L. REv. 445, 471-74 (1987).

42. T. Marmor, The Politics of Medicare 72 (rev. ed. 1973); Steinwald, Hospilal-Based Physicians: Current Issues and Descriptive Evidence, 2 Health Care Financing Rev. 63, $168-69$ (Summer 1980).

43. M. Roemer \& J. Friedman, supra note 18; Sloan \& Becker, Internal Organization of Hospitals and Hospital Costs, 18 InQUiRY 224 (Fall 1981).

44. Even before the merger, Blue Cross and Blue Shield plans functioned as single firms in the areas they served. See Frech \& Ginsburg, Competition Among Heallh Insurers, in Competition IN THE Health Care Sector: Past, Present and Future 167, 169 (W. Greenberg ed. 1978). 
hospital care under Part A and for physicians' services under Part B. ${ }^{45}$ The continued ability of physicians to bill separately for services performed in hospitals has not only served to maintain their economic independence of hospitals but their professional independence as well. While an employed physician is presumably free to quit if he dislikes a particular decision by a hospital administrator, virtually all the self-employed physician has to do is to park his car in another hospital parking lot. Since doctors have traditionally referred patients to hospitals, they have controlled the hospitals' clientele. That power over patients adds to physicians' autonomy. Thus, continued independence has given physicians, both individually and collectively, considerable leverage over hospitals.

Third, several decisions by the courts have affected hospital-physician relations. In Darling $v$. Charleston Community Memorial Hospital, ${ }^{46}$ the court ruled that the hospital governing board has a responsibility to evaluate, counsel, and if necessary take action to prevent unreasonable risk of harm by physicians to patients treated in their facilities. The effect of this ruling was to make the hospital a potential co-defendant in malpractice suits brought by patient plaintiffs. ${ }^{47}$ Even though the hospital board has formal legal authority to determine membership on the hospital medical staff, boards often do not appear to exert their authority over medical staffs; that is, the boards may provide no more than rubber stamps of decisions arrived at by medical staffs. ${ }^{48}$ Frequent reminders to the effect that hospital board members have an important oversight responsibility provide some indication that this responsibility is still not universally understood. ${ }^{49}$

Two major recent developments have had the effect of reducing the power of physicians relative to hospitals. First, physicians' leverage over hospitals arose in part because hospitals had to compete to obtain admitting physicians. This has particularly been a problem for rural hospitals. Physician control over referrals of patients has been a fundamental element of their economic influence with hospitals. However, physicians are no longer as scarce as they once were. Hospital bed supply is no longer increasing. The total number of non-federal short-term general and other special hospitals ("community hospitals") reached its peak in 1975; total beds in such hospitals peaked in $1983 .{ }^{50}$ Yet physician supply has expanded rapidly ${ }^{51}$ and will continue to

45. G. Harrington, The Medicare Answer Book 4-5, 8-10, $12-15$ (1982).

46. 33 Ill. 2d 326, 211 N.E.2d 253 (1965), cert. denied, 383 U.S. 946 (1966).

47. For other cases that have served to define the roles of hospital governing boards vis-a-vis their medical staffs, see, for example, St. John's Hosp. Medical Staff v. St. John's Regional Medical Center, 245 N.W.2d 472 (S.D. 1976); Weary v. Baylor Univ. Hosp. 360 S.W.2d 895 (Tex. 1962); Purcell v. Zimbelman, 500 P.2d 335 (Ariz. C. App. 1972); Gonzales v. Nork (Cal. Super. Ct., Nov. 19,1973 ).

48. E. Freidson, Doctoring Together: A Study of Professional Social Control 105-19 (1975).

49. See, e.g., Dreuth, supra note 23; see also D. Warren, Problems in Hospital Law 49-56 (1978).

50. American Hospital Ass'n, Hospital Statistics, 1986 Edition 4 (1987).

51. American Medical Ass'n, Physician Characteristics and Distribution in the U.S., 1987 EDITION 9 (1987). 
grow at about the same pace for the foreseeable future. ${ }^{52}$ The growth in the physician-to-hospital ratio is a potential major source of bargaining strength for hospitals. Moreover, in response to competitive pressures, hospitals have sought to attract patients directly through advertising and by developing specialized services that appeal to a particular market niche. In addition, hospitals have developed physician referral services, thereby exercising some countervailing leverage on doctors.

Second, changes in third party reimbursement-such as implementation of the Prospective Payment System by Medicare ${ }^{53}$ and the increasing number of capitated health plans ${ }^{54}$-and the growth of competition among hospitals give hospitals ${ }^{55}$ an incentive to be concerned about efficiency and cost containment. Costs are partly influenced by the patterns of practice of the hospital medical staff. ${ }^{56}$ Concern about cost containment gives hospitals' management a powerful incentive for exercising greater managerial oversight, even if this means locking horns with the medical staff over matters once deemed within physicians' sphere of professional autonomy. Hospitals are being forced increasingly to act in their own self-interest rather than just functioning as "doctors' workshops." Moreover, as payers have developed greater consciousness over costs and greater sophistication as prudent purchasers of medical care, they have increasingly made independent arrangements with hospitals. This provides hospitals with an incentive, through more aggressive management practices, to restrain costs. It also provides some counterbalance to physicians' economic leverage since hospitals have additional sources of patient referrals.

2. Economic Models of the Hospital. The private not-for-profit hospital is the dominant producer of hospital care in the United States. In 1986, 58 percent of all community hospital beds were located in such institutions. By contrast, for-profit and public hospitals accounted for only 15 and 27 percent of community hospital beds, respectively. ${ }^{57}$ Several studies have attempted to provide ex post justifications for the dominance of the not-for-profit ownership form. Some assert that medical care is practically unique in that patients are unable to gauge the quality and appropriateness of the care they

52. U.S Dep't of Health and Human Services, Fifth Report to the President and Congress on the Status of Health Personnel in the United States (1986) [hereinafter Fifth Report to The President]; see also Schwartz, Sloan \& Mendelson, Why There Will be Little or No Physician Surplus between Now and the Year 2000, 318 NEw ENG. J. MED. 892 (1988).

53. Guterman \& Dobson, Impact of The Medicare Prospective Payment System for Hospitals, 7 HEALTH Care Fin. Rev. 97 (Spring 1986).

54. InterStudy, National HMO Census 1985 (1986); InterStudy, 1986 National HMO Firms: A Report on Companies that Own or Operate HMO's in Two or More States (1987); Langwell \& Hadley, Capitation and the Medicare Program: History, Issues, and Evidence, 1986 Ann. Supp. Health Care Fin. Rev. 10 (1986).

55. Robinson \& Luft, Competition and the Cost of Hospital Care, 1972-1982, 257 J. A.M.A. 3241 (1987).

56. See Sloan \& Becker, supra note 43; Pauly, Medical Staff Characteristics and Hospital Costs $13 \mathrm{~J}$. Hum. Resources 77 (Supp. 1978).

57. Fifth Report to the President, supra note 52, at 4. 
receive or ought to receive. ${ }^{58}$ As a consequence, patients expect physicians to give priority to their health needs without regard to the providers' own pecuniary gain. Providers are well-positioned to dupe consumers, and health businesses can make considerable profits by doing so. ${ }^{59}$ Patients, so the argument goes, would rather deal with hospitals that do not have profitmaking as an organizational objective.

A related argument is that donors cannot take the time to determine whether their subsidies are put to good use. Hence they would rather give money to a not-for-profit than a profit-seeking organization which might be more easily tempted by the prospect of monetary gain. ${ }^{60}$

The consumer/donor ignorance set of arguments has important weaknesses. To the extent that physicians admit patients to the hospital, order diagnostic tests, and perform surgical procedures on their hospitalized patients, there is a strong case for a not-for-profit physician firm rather than for a not-for-profit hospital. There is no empirical evidence to support the view that managers of not-for-profit organizations are less likely to be tempted by the prospect of pecuniary gain than their counterparts in forprofit organizations.

Another purported justification for the predominance of the not-for-profit hospital form is that, by not maximizing profits, the not-for-profit hospital provides a mix of socially desirable outputs that a profit-maximizing hospital would not choose to provide. ${ }^{\circ 1}$ There are several weaknesses to this argument. First, it assumes a behavioral model of the not-for-profit hospital that may or may not exist. To the extent that a "surplus" is substituted for a "profit," it is unclear how these surplus funds are spent. It may be, for example, that a potential "surplus" is dissipated through operating inefficiencies that creep into organizations not faced by pressures to perform for the bottom line. Second, there is a fundamental issue of legitimacy. In accordance with whose set of priorities are surplus funds spent? Is this a form of taxation or appropriation of public funds? If so, who determines the level of revenue raising and the incidence of the disguised taxation? What modes of accountability exist? Third, it would be generally more efficient to provide explicit subsidies for socially desirable outputs or at a minimum establish explicit standards of behavior for the receipt of non-profit status.

An even less favorable view of the dominance of the not-for-profit form is that physicians operate such hospitals in the interest of a local physician cartel. $^{62}$ In this view, community hospitals are passive agents of the

58. Arrow, supra note 24.

59. Relman, The New Medical-Industrial Complex, 303 New EnG. J. Med. 963 (1980); Sloan, Property Rights in the Hospital Industry, in Hralth Care in America: The Political Economy of Hospitals and Health Insurance 108-11 (H. Frech ed. 1988).

60. Hansmann, The Role of Nonprofit Enterprise, 89 Yale L.J. 835 (1980); Easley \& O'Hara, The Economic Role of the Nonprofit Firm, 14 BELL J. ECON. 531 (1983).

61. See, e.g., Relman, supra note 59.

62. Pauly \& Redisch, The Not-for-Profit Hospilal as a Physicians Cooperative, 63 Am. Econ. Rev. 87 (1973); Shalit, A Doctor-Hospital Cartel Theory, 50 J. of Bus. 1 (1977). 
physicians. In one variant, local physicians determine the number of physicians who should be allowed to practice in the community so as to maximize mean physician income. Once the profit-maximizing number of physicians is reached, the doctors exclude all potential entrants from the hospital's medical staff. Without the prospect of practicing in the hospital, no physician would locate in the town.

To link cartelization with the predominance of the private not-for-profit hospital, one must explain why doctors choose to organize most often at a voluntary rather than a for-profit hospital. An argument that physicians prefer organizational slack seems implausible. Why should doctors want to squander any of their income on "perks" for managers or to pay hospital employees more than the minimum pay level required to hire them? ${ }^{63}$ The cartel-run hospital might often offer an allocatively inefficient mix of outputs, but, if tightly managed, would not be wasteful in these ways.

Robert Clark ${ }^{64}$ has suggested why doctors may prefer to deal with voluntary hospitals. First, physicians may find it easier to divide the profits of a non-profit than a for-profit hospital. With the for-profit form, doctors have to share profits with equity-holders. Second, physicians may prefer non-profit hospitals because the tax advantages available to such hospitals presumably leave a larger residual for medical staff members to claim. Third, the not-forprofit form may facilitate physician control over hospital staff privileges. Local physicians might have much more difficulty exercising such control if the hospital were owned by a publicly-held corporation. Fourth, patients may have greater trust in a not-for-profit hospital.

Not all private not-for-profit hospitals fit perfectly into the cartel mold. For example, the fit is not good for hospitals with close affiliations with a medical school. Such hospitals are not controlled by community doctors; in fact, "town" and "gown" physicians increasingly compete for patients. ${ }^{65}$ Having a single hospital in a market area is the exception rather than the rule. ${ }^{66}$ Thus, even if members of a hospital's medical staff conspire to exclude other physicians from practicing in their hospital, the physicians are not automatically excluded from practice in the hospital's market area. Although not-for-profit hospitals are in the majority, they do frequently compete with public and for-profit hospitals. The latter types of hospitals are not subject to the same kind of physician control. Public hospitals typically have open

63. Martin Feldstein has noted that it has been hypothesized that hospitals spend profits on workers by paying them more than they could receive in other industries, the "philanthropic wage hypothesis." M. Feldstein, The Rising Cost of Hospital Care 52, 68-69 (1971). Not only are there conceptual problems with the hypothesis, as mentioned in the text, but empirical support for the hypothesis is lacking. See, e.g., F. Sloan \& B. Steinwald, Hospital Labor Markets: Analysis of WAGES AND WORK-FORCE COMPOSITION 49-79 (1980).

64. Clark, Does the Nonprofil Form Fit the Hospital Industry?, 93 Harv. L. Rev. 1416, 1441-47 (1980).

65. Sloan, Perrin \& Valvona, The Teaching Hospital's Growing Surgical Caseload, 254 J. A.M.A. 376 (1985).

66. Morrisey, Sloan \& Valvona, Defining Geographic Markets for Hospital Care, Law \& ConTEmP. Probs., Spring 1988, at $165,180-84$. 
staffing. ${ }^{67}$ When the physician owns a proprietary hospital, as equity-holder, he is best served by running the hospital so as to maximize profit. Publiclyheld hospital companies are ultimately accountable to the shareholders rather than to the medical staffs of their local affiliate hospitals.

In a model developed by Jeffrey Harris, ${ }^{68}$ hospital decisionmaking takes place on two tracks. As agents for their patients, physicians demand resources from the hospital, including hotel days, laboratory services, and specialized nursing care. The medical staff constitutes the hospital's "demand division." The hospital administration runs the organization that provides facilities and services to the physicians' patients, the "supply division." The Harris model does not exclude the possibility of a doctor-run cartel, but the author uses it to make a general point about the important role physicians play in decisions made within the hospital setting, such as in determining hospital utilization patterns. Hospital services and physicians' services performed on hospitalized patients are purchased jointly. A cost-containment policy that focuses on the supply division, such as certificate-of-need or controls over hospital prices, can easily be circumvented by the hospital's doctors. For example, a rate-setting authority may attempt to constrain the price of a laboratory test performed in the hospital, but this type of control can be circumvented by the hospital's doctors since they have the prescribing power to raise the number of tests performed per admission.

Drawing on the economics literature on physician-hospital relationships, Kissam, Webber, Bigus, and Holzgraefe defined three models. ${ }^{69}$ The first is a pure "physician cartel" model in which physicians' self-interest dictates who can practice at the hospital. ${ }^{70}$ In a second, the "joint venture" model, the medical staff and the hospital each pursues its own interests. However, on some issues, the results pursued in the furtherance of these interests coincide. For example, in supporting a requirement that all physicians able to practice at the hospital be board certified, the existing medical staff may desire to protect itself from potential competitors. The hospital may agree to this requirement, but its motivation would be to boast of a high quality hospital.

In the third model, the "employer hospital," the hospital pursues its interest, for example in contracting with a group of radiologists who provide continuous coverage, have responsibility for selecting the hospital's radiological equipment, and supervise quality of care in the $\mathrm{x}$-ray department. In this model, the hospital is in a vertical relationship with its medical staff. One could think of many examples in which two of the models were descriptive of hospital-physician relationships within a single institution. For instance, a hospital could conduct a national search for a group of

67. See D. WARREN, supra note 49.

68. See Harris, The Internal Organization of Hospitals: Some Economic Implications, 8 Br.LL. J. ECon. 467 (1977).

69. Kissam, Webber, Bigus \& Holzgraefe, Antitust and Hospital Privileges: Testing the Comventional I'isdom, 70 Calif. L. REv. 595 (1982).

70. Their cartel model is clearly in the spirit of the Pauly-Redisch model and, in some cases, the Harris model as well. See Pauly \& Redisch, supra note 62. 
pathologists which it retains on a contractual basis. Yet the surgical staff might operate as a local cartel.

3. Sociological and Organizational Perspectives. While to economists the inner workings of a hospital constitute largely a "black box," sociologically-oriented research has delved inside the box. In a very well-known study, Roemer and Friedman quantified the tightness of hospital medical staff organization ("MSO") along several dimensions: composition of the staff, including the credentials of medical staff members; appointment procedure, such as the nature of the physician selection process and the service obligations of members once admitted; commitment, such as method of remunerating physicians for work performed at the hospital, with fee-for-service separate billing at one end of the spectrum and full-time salaried practice at the other; institutional affiliations-the number of hospitals at which a staff member can have privileges with stringent limitations suggesting greater MSO; departmentalization, with lots of departments and subdivisions indicating more control; presence of control committees, such as an interdepartmental committee for drug dispensing; documentation-extent to which there are detailed bylaws and formal reports on various hospital activities; and informal dynamics- "safety valves" which provide a vehicle for bypassing the formal hospital organizational structure. ${ }^{71}$ Higher MSO means a "tighter ship" and describes more of a vertical relationship between hospitals and their doctors in which the hospital is the buyer. Roemer and Friedman presented ten hospital case studies which spanned the gamut in terms of MSO scores. The study serves to emphasize both the diversity of the hospital organization and the type of detailed empirical analysis needed to understand adequately the physician-hospital relationship at a particular institution.

There is only limited empirical evidence that describes the circumstances under which specific forms of internal organization arise within the hospital. Feldman and co-authors assessed one aspect of the hospital-physician relationship-the fraction of full-time equivalent physicians on salary at the hospital. While the hospital tends to have at least more nominal control over salaried physicians than over those on independent fee-for-service status, there is also a cost to the hospital of monitoring physician output. The feefor-service system gives the individual doctor an incentive to produce output independently of supervision and work norms. Hospitals often choose formal contractual arrangements, of which salaried practice is one form, when the continuous presence of a physician at the hospital is required. Emergency room physicians, anesthesiologists, radiologists, and pathologists must always be present and often have formal contracts with hospitals. Research and teaching outputs are much more difficult to define than "pure" patient care, and for this reason, salaried practice tends to be both a more efficient and equitable form of compensation in hospitals where such outputs are relatively

71. M. ROEMEr \& J. Friedman, supra note 18, al 83-102. 
important. In areas where doctors are relatively plentiful, they appear to be more willing to work at hospitals for a salary.

Freidson ${ }^{72}$ examined the informal dynamics of physician groups by means of intensive interviews and direct observation. He found that hospital administration had formal authority to take specific actions. Such formal authority often rested on a direct mandate from the hospital's board of trustees. Nevertheless, the physicians were willing to concede legitimacy of administrative authority in only a limited number of areas. As a result, administration minimized its use of formal authority. Even chiefs of medical service, themselves physicians, were reluctant to give orders. Even unsolicited advice was resented. ${ }^{73}$

Freidson's description of peer review within the hospital suggests such review tends to be quite limited in scope. "The most readily available source of information that was used to assess colleagues was their formal credentials-the medical degree itself and specialty board status being important credentials." 74 Opinions about a colleague were often influenced by the comments of patients. "The patient was perhaps the major source of information about the skill, compassion, and conscientiousness employed by colleagues in dealing with, or managing, patients."75 Physicians seeking information about a particular colleague "were able to obtain information about him from other colleagues." 76 This was an especially good source of information when a physician wanted to find out about a colleague in another specialty. ${ }^{77}$ Many physicians were reluctant to rely on secondary sources of information about a colleague. "Many physicians were inclined to claim that they suspended judgment without direct experience and that they tested others' opinions about their first-hand experience with the person involved." 78 One type of first-hand experience dealt with the competence of the physician who referred the case. There was extreme reluctance to discuss mistakes that would be considered "normal" as opposed to "deviant."7o, "Many secrets about physician performance were kept rather well in the medical group." "80

Although the medical chart was considered to be the most objective source of information on physician performance, "the medical record was not used deliberately and systematically by the group physicians as a source of information about performance." 81 A committee of distinguished outside consultants carried out chart review under the auspices of the insurance plan. Physicians in the medical group accepted the findings when they were

\footnotetext{
72. E. Freidson, supra note 48, at 263-75.

73. Id. at 118 .

74. Id. at 139

75. Id. at 141 .

76. $\quad$ Id. at 142 .

77. Id. at 143 .

78. Id. at 145 .

79. Id. at 162-63

80. Id. at 165 .

81. Id. at 169 .
} 
positive, but rejected the findings out of hand when they were critical of colleagues. ${ }^{82}$ "Indeed, the idea of chart review threatened their most basic conceptions of themselves as physicians." 83 Freidson considered that "the record was (thus) a legitimate enough source of information about colleague performance, but it was legitimate to examine only a record that normally came into one's hands in the course of work. To make an effort to seek out any other record and examine it was prying." 84

In sum, Freidson's work suggests that (1) the medical staff sought and obtained considerable autonomy from the hospital, especially in clinical matters, and (2) to the extent that internal peer review took place, it tended to be informal and quite limited in scope and amount. The underlying motives were at least as much to exercise professional autonomy as to cartelize, a possibility Freidson did not explicitly consider.

4. Implications. Our review of the historical, economic, and sociological literatures has these major implications for antitrust analysis of hospital peer review.

Throughout most of this century, physicians have fought to be free of domination by hospitals. Physicians have fought in the political arena and at the level of individual hospitals where hospitals have had to compete for admitting physicians. Many of the institutional arrangements that have evolved, although expressed in terms of patient welfare, have had the not-sohidden agenda of protecting physicians' professional independence and their incomes. Physicians are no longer as dominant nationally and locally as they once were, and competitive pressures are increasingly forcing hospitals to act in their own self-interest for reasons we have noted. Yet there is ample room for suspicion that many of these institutional arrangements undoubtedly remain in many local hospital markets. The "employer hospital" relationship describes only a minority of physician-hospital relationships. Reviewing the sociological evidence, one is struck by the diversity of relationships between doctors and hospitals as well as the importance of the constraints on effective peer review at the hospital level. Both the diversity and the limitations on effective peer review suggest a need for case-by-case scrutiny. Although notfor-profit hospitals are the dominant organizational form in this industry, there is no reason to exclude economic motives on the part of the hospital's administration or the hospital's medical staff.

82. Id. at 170 .

83. Id. at 174 .

84. Id. at 175 . 


\section{III}

\section{Antitrust Doctrine: An Overview of the General Issues}

In the application of the antitrust laws ${ }^{85}$, there is a "basic distinction between concerted and independent action." 86 Section 1 of the Sherman Act, ${ }^{87}$ for example, proscribes concerted activities such as contracts, combinations, or conspiracies that unduly restrain trade. Section 1 , however, does not forbid independent action. ${ }^{88}$ An economic entity "generally has a right to deal, or refuse to deal, with whomever it likes, as long as it does so independently." 89

The bar against anticompetitive concerted activity places into perspective the antitrust problem confronting institutionalized peer-review activities. By definition, hospital peer review involves a form of concerted activity. If it is the type of concerted activity that falls within the ambit of section 1 of the Sherman Act, it will be subject to searching scrutiny to determine whether its overall consequences are pro- or anticompetitive.

Although the antitrust principles associated with concerted activity are in a period of reassessment, ${ }^{90}$ it seems that horizontal concerted action will be viewed more severely than comparable action when it is vertical in character. Horizontal restrictions-that is, those among competitors-are typically seen as extraordinarily dangerous to competition. Vertical restrictions are now understood more often to have both pro- and anticompetitive dimensions, necessitating ad hoc investigation on a fact-specific basis. ${ }^{91}$

85. At the threshold, the federal antitrust laws apply only where the defendant's conduct is either "in" or substantially affects interstate commerce. McLain v. Real Estate Bd., 444 U.S. 232,241 (1980). The issuc, perhaps surprisingly given McLain and Hospital Bldg. Co. v. Trustees of Rex Hosp., 425 U.S. 738 (1976), is often a stumbling block at the jurisdictional stage in hospital staff privileges cases. Compare Sarin v. Samaritan Health Center, 813 F.2d 755, 757-58 (6th Cir. 1987), and Doe on Behalf of Doe v. St. Joseph's Hosp., 788 F.2d 411, $416-17$ (7th Cir. 1986), with Shahawy v. Harrison, 778 F.2d 636, 638-41 (11 th Cir. 1985), and Cardio-Medical Assocs., Ltd. v. Crozier-Chester Medical Center, 721 F.2d 68, 74 (3d Cir. 1983). As stated by the Court of Appeals for the Eleventh Circuit, "[the central dispute [between the circuits] is whether defendant's general business activity or its specific anti-competitive conduct is to be measured for substantial effect on interstate commerce." Shahawy, 778 F.2d at 639-40. The circuits applying a more restrictive commerce clause jurisdictional approach require that there be a nexus between the defendant's allegedly illegal activities and the substantial effect on interstate commerce. A general allegation that the defendant's business activities overall or a portion of those activities affect commerce is insufficient to overcome the commerce clause's jurisdictional prerequisites. See Seglin v. Esau, 769 F.2d 1274, 1280 (7th Cir 1985). In the less restrictive circuits, the relevant inquiry is whether "as a result of the anticompetitive conduct," the course of interstate commerce is "different from the transactions that would otherwise have occurred." Cardio-Medical Assocs., 721 F.2d at 74. To satisfy the commerce clause jurisdictional requirement, a plaintiff need only show that "defendant's business activities have a substantial impact on interstate commerce." Shahawy, 778 F.2d at 641 .

86. Monsanto Co. v. Spray-Rite Serv. Corp., 465 U.S. 752, 761 (1984).

87. 15 U.S.C. $\$ 1$.

88. Monsanto Co. v. Spray-Rite Serv. Corp., 465 U.S. 752, 761 (1984).

89. Id.

90. See, e.g., FTC v. Indiana Fed'n of Dentists, 476 U.S. 447 (1986); Northwest Wholesale Stationers, Inc. v. Pacific Stationery \& Printing Co., 472 U.S. 284 (1985); NCAA v. Board of Regents, 468 U.S. 85 (1984).

91. Antitrust enforcers, courts, and analysts more generally in recent years have been more tolerant of vertical than horizontal restraints. The motives for and effects of vertical restraints more 
frequently can be justified as efficiency-enhancing. O. Williamson, Markets and Hierarchies: ANAlysis and AnTitrust Implications (1975); Krattenmaker \& Salop, Anticompetitive Exclusion: Raising Rivals ' Costs to Achieve Power over Price, 96 YaLe L. J. 257 (1986). In addition, upon scrutiny the danger to competition from a vertical combination often arises because of the presence of a monoply at one or more stages of production. Therefore, it is not always the vertical restraint that is troublesome from the perspective of competition. Inquiry in those cases must focus on the nature and effect of the horizontal restraint.

Included among the potential efficiency-enhancing effects of vertical integration are economiesof-scope between upstream and downstream stages of production, uncertainty in supply of the upstream product, and savings in various transactions costs that can be realized by internalizing a transaction; that is, when the savings in transaction costs exceed the benefits of conducting business through organized markets. Arrow, Vertical Integration and Communication, 6 BELL.J. ECON. 173 (1975); Carleton, I'ertical Integration in Competitive Markets under Uncertainty, $27 \mathrm{~J}$. OF IND. ECoN. 189, 196-98 (1979); O. Williamson, supra.

Economies-of-scope reflect technological interdependencies. For example, in the steel industry, blast furnaces, converters, and reduction mills tend to be owned by a single firm to avoid reheating the steel as it moves from one production stage to the next. See R. Blair \& D. Kaserman, Antitrust ECONOMICs 291-92 (1985).

To reduce the chances of supply shortages, a gasoline refiner may wish to own its own oil wells. In a health context, a hospital may contract with a group of anesthesiologists to assure the continuous presence of such physicians at the hospital. Without such doctors, the hospital may not be able to operate on patients on an emergency or unscheduled basis. Futures markets provide a vehicle for reducing supply uncertainty in a number of industries. Thus, with the growth of futures markets, in general, the supply uncertainty argument for vertical combinations is not as compelling as it once was. See U.S. Dep't of Justice, 1985 Vertical Restraint Guidelines 40-45 (Jan. 23, 1985).

Frequent negotiations between buyers and sellers of products at successive stages of production may sometimes be more costly than having managers arrange for the transfer of a product from the upstream division to the downstream division of an integrated firm. Firms may have to expend resources to guard against opportunistic behavior on the part of an antagonistic negotiating partner. By integrating, such strategic behavior can be avoided. Also, it may be easier for the manager of an integrated firm to penalize employees deemed responsible for breakdowns at the various stages of production than to have to deal with a deficiency in an outside organization. See Williamson, The Economics of Antitrust: Transaction Cost Considerations, 122 U. PA. L. REv. 1439 (1974); Williamson, The lertical Integration of Production: Market Failure Considerations, 61 AM. ECon. REv. 112 (1971).

Exclusive retail franchises can also be justified on grounds of reduced transactions costs. The exclusive franchises may have a greater incentive to learn about and promote the product. Thus, the manufacturer has to devote fewer resources to monitoring the behavior of retail firms that sell its products.

Vertical integration may also have an effect on the cost of capital faced by firms. The cost of equity capital depends on the level of "systematic risk" associated with investments in the firm's securities. The systematic risk is that risk that cannot be eliminated by investors through portfolio diversification. The reason such risk cannot be diversified away is that it results from shocks to the firm's demands and costs that are correlated with economy-wide factors, such as recessions. Recent empirical work suggests that vertical mergers reduce systematic risk and hence the cost of equity capital to the firm. Spiller, On Vertical Mergers, I J. L. Econ. \& Org. 285 (1985); Helfat \& Teece, lertical Integration and Risk Reduction, 3 J. L., ECON. \& ORG. 47 (1987).

Potential efficiency gains from vertical arrangements must of course be weighed against any potential harm to competition. Such harm arises when there is monopoly power at one or more of the stages of production which through a vertical combination is linked (o) stages which otherwise would be competitive. Such monopoly power may arise for a legal reason (c.g., a patent) or from horizontal market power at one or more stages that demands antitrust scrutiny. Ihus. in the final analysis, concern about vertical restraints may not always be so much with its "vertical" characteristic as with the horizontal restraints with which it may be anchored.

Horizontal restraints can also be justified as efficiency enhancing, such as mergers to realize scale economies. Some experts have doubted that economies-of-scale in production could oficu be achieved through horizontal mergers, but evidence and attitudes about this are changing. Sit. f.g. F. Scherer, Industrial Market Structure and Fconomic Performancr. 133 -38 (198(1)). As : alternative to merging, economies-of-scale can be realized by having some of the existing competitors within the industry expand their outputs. Mergers may also sometimes be a substitute for outright firm closings or a mechanism for climinating ineffective management all ome or more of 
At one time, certain non-price vertical restrictions were deemed per se illegal.92 Concerted activity is deemed per se illegal when it has a "pernicious effect on competition and lack $[s]$. . . any redeeming virtue."93 Such "agreements or practices . . . are conclusively presumed to be unreasonable and therefore illegal without elaborate inquiry as to the precise harm they have caused or the business excuse for their use."94 In 1977, the Supreme Court concluded that non-price vertical restrictions often had "redeeming virtues" that offset their anticompetitive effects. ${ }^{95}$ As a result, the Court held that, as a general rule, non-price vertical restraints must be evaluated on a case-by-case basis under the rule of reason-a detailed inquiry into whether the particular restriction, on balance, advances or impedes competition. ${ }^{96}$ In contrast, the Court noted that comparable types of horizontal restrictions among competitors-territorial divisions-would continue to be illegal per se. ${ }^{97}$

Thus, characterizing a restraint as vertical or horizontal is an analytically important first step. As the Supreme Court recognized in the GTE Sylvania case, ${ }^{98}$ there may be agreements that have both vertical and horizontal features. This may pose problems of "differentiating vertical restrictions from horizontal restrictions" in some circumstances. ${ }^{99}$ As we discuss later on, this can be a particularly tricky, yet important, issue in the hospital peer-review context.

Even as to horizontal agreements, however, the Supreme Court has relaxed some of the harshest elements of traditional doctrine. Although horizontal price ${ }^{100}$ or territorial agreements ${ }^{101}$ remain illegal per se under the Sherman Act, the Court has been more willing recently to allow defendants to explain, in defense of their conduct, the benefits to competition that arise from collaborative activity. For example, where horizontal restraints can be characterized as ancillary and "essential if the product is to be available at all," 102 the Court has declined to declare even price-fixing agreements per se illegal. ${ }^{103}$ Instead, it has engaged in a detailed investigation of the impact on

the merging firms. However, there are three types of horizontal restraints with few if any efficiencyenhancing justifications such as price-fixing, market division, and boycotts.

92. See U.S. v. Arnold Schwinn \& Co., 388 U.S. 365 (1967).

93. Northern Pac. R. Co. v. United States, 356 U.S. 1, 5 (1958).

94. Id.

95. Continental T.V., Inc. v. GTE Sylvania Inc., 433 U.S. 36, 54 (1977).

96. See Business Elecs. Corp. v. Sharp Elecs. Corp., 108 S. Ct. 1515 (1988). See generally 7 P.

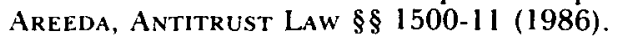

97. GTE Sylvania Inc., 433 U.S. at 58 n.28. See also United States v. Topco Assocs., Inc., 405 U.S. $596,608(197 \dot{2})$.

98. 433 U.S. 36 (1977).

99. Id. at 58 n.28. See also Business Elecs. Corp. v. Sharp Elecs. Corp., 108 S.Ct. 1515, 1523 n.4 (1988).

100. See., e.g., Arizona v. Maricopa County Medical Soc'y, 457 U.S. 332 (1982).

101. See, e.g., United States v. Topco Assocs., Inc., 405 U.S. 596 (1972).

102. NCAA v. Board of Regents, 468 U.S. 85, 101 (1984).

103. See Broadcast Music Inc. v. Columbia Broadcasting Sys., Inc., 441 U.S. 1 (1979). 
competition of the challenged activities determining "whether or not the challenged restraint enhances competition."104

\section{A. The Nature and Scope of Permissible Justifications}

Since the Court has been wary of expanding the categories of cases subject to the per se rule of invalidity, and since, in particular, it has "been slow to condemn rules adopted by professional associations as unreasonable per se," 105 the question of the nature and scope of acceptable justifications for restrictive conduct emerges as of critical importance. In relying to a greater extent on ad hoc evaluations of restrictive conduct on competitive impact, the Court has argued that certain types of restrictive activity may be procompetitive in operation. ${ }^{106}$ The fundamental justification for enhanced reliance on rule of reason analysis is a growing sense on the part of the Court-which in this regard is reflecting the scholarly literature-that some types of superficially restrictive conduct may, overall, have a positive effect on the system of competition. ${ }^{107}$

Thus, in FTC v. Indiana Federation of Dentists, ${ }^{108}$ the Court noted that a horizontal refusal to compete by a group of dentists cannot be upheld in a rule of reason analysis unless defendants can demonstrate an offsetting "countervailing pro-competitive virtue."109 The Court has rejected arguments that "the special characteristics of a particular industry" justify "monopolistic arrangements" on the ground that they "will better promote trade and commerce than competition."110 Justifications for collective restraints must be found in their countervailing procompetitive character. Antitrust inquiry focuses exclusively on the "challenged restraint's impact on competitive conditions." 111 The purpose of a rule of reason analysis "is to form a judgment about the competitive significance of the restraint; it is not to decide whether a policy favoring competition is in the public interest, or in the interest of the members of an industry." 112 The policy decision in favor of competition has been made by the Sherman Act, which "reflects a legislative judgment that . . competition is the best method of allocating resources in a free market . . . ."113 Arguments about the desirability of procompetitive practices in a particular industry are not for courts to adjudicate because the procompetitive policy underlying the Sherman Act "precludes [judicial]

104. NCAA v. Board of Regents, 468 U.S. 85, 104 (1984).

105. FrC v. Indiana Fed'n of Dentists, 476 U.S. 447, 458 (1986).

106. See, e.g., Continental T.V., Inc. v. GTE Sylvania Inc., 433 U.S. 36, 54-59 (1977).

107. For a skeptical view of this development in the caselaw and a critique of the economic literature, see Comanor, Vertical Price-Fixing, Vertical Market Restrictions, and the New Antitrust Policy, 98 HARV. L. REv. 983 (1985).

108. 476 U.S. 447 (1986).

109. Id. at 459 .

110. National Soc'y of Professional Eng'rs v. United States, 435 U.S. 679, 689 (1978).

111. Id. at 688 .

112. Id. at 692 .

113. Id. at 695 . 
inquiry into the question whether competition is good or bad."114 That type of argument is "properly addressed to Congress,"115 which has enacted exemptions from the antitrust laws for specific circumstances and specific industries, 16 including institutionalized peer review. ${ }^{117}$

Nevertheless, the Supreme Court has intimated that it will not automatically apply to the professions antitrust precepts developed in the context of business. 18 Some courts have viewed that type of admonition as an invitation to establish what might be termed a "worthy purpose" defensethat is, to permit values other than competition to enter into the antitrust analysis as a justification for certain types of anticompetitive professional activity. 19 This is an entirely different, more far-reaching, and questionable defense for anticompetitive activity that would otherwise be deemed illegal. ${ }^{120}$

The most significant decision that recognizes such a worthy purpose defense for otherwise anticompetitive conduct is the Court of Appeals for the Seventh Circuit's decision in Wilk v. AMA, ${ }^{121}$ a case brought by chiropractors alleging a concerted refusal to deal by the American Medical Association ("AMA") and its members. The court of appeals conceded that the trial court's jury instructions did not focus exclusively on the question whether the AMA's challenged conduct "promoted or suppressed competition between medical doctors and chiropractors." 122 Rather, the trial court's instructions gave "recognition to values other than those associated with unrestrained competition." 123 That is, the trial court's theory apparently permitted the jury to balance, under the rule of reason, adverse effects on competition with "some value unrelated to free competition." 124

In review of the trial court's decision, the Seventh Circuit expressly held that under a rule of reason analysis, a "value independent of the values attributed to unrestrained competition must enter the equation."'125 The court concluded that the rule of reason inquiry must accommodate medical doctors' legitimate professional judgment that adherence to the scientific method, not (according to the AMA) utilized by chiropractors, was important for the health of the medical doctors' patients. Defendants argued that their associating with chiropractors, who did not "share respect for scientific

\footnotetext{
114. Id.

115. Id. at 689 .

116. See id. at 690 n.14, 695 n.18.

117. Health Care Quality Improvement Act of 1986, 42 U.S.C. $\$ \$ 11101$ et seq. (Supp. 1988).

118. See Goldfarb v. Virginia State Bar, 421 U.S. 773, 788-89 n.17 (1975).

119. See, e.g. Wilk v. AMA, 719 F.2d 207 (7th Cir. 1983), on remand 671 F. Supp. 1465 (N.D. Ill. 1987).

120. See generally Kauper, The Role of Quality of Health Care Considerations in Antitrust Analysis, LAw \& Contemp. Probs., Spring 1988, at 273, 304-324.

121. 719 F.2d 207 (7th Cir. 1983).

122. Id. at 225 .

123. Id.

124. Id. at 224 .

125. Id. at 227.
} 
method,"126 would endanger the health and even the lives of their patients. ${ }^{127}$ In accepting the legitimacy of this argument as a defense to an antitrust claim, the court of appeals stated that the "reasonableness" of a "restraint on competition" from defendants' concerted refusal to deal with chiropractors had to be "determined by a reconciliation of values of differing kinds."128

The appropriateness of this extraordinary introduction of noncompetition values into an antitrust rule of reason analysis is far from clear. The Seventh Circuit purported to rely on Justice Blackmun's concurring opinion in Professional Engineers. ${ }^{29}$ The court of appeals noted that "Justice Blackmun regretted the intimations he found in the Court's opinion that any ethical rule with an overall anticompetitive effect promulgated by a professional society is forbidden by the Act."130 According to the Seventh Circuit, Justice Blackmun urged a more flexible approach, one that would "take account of benefits other than increased competition" and would "recognize "that there may be ethical rules which have a more than de minimis anticompetitive effect and yet are important in a profession's proper ordering.' "'131

A fair reading of Professional Engineers raises serious questions about the propriety of the Wilk court's analysis of the legitimate scope of antitrust defenses under the rule of reason. Justice Blackmun explicitly declined to join a portion of the majority's opinion in Professional Engineers precisely because he believed that the Court had gone too far in rejecting any rule of reason defenses other than those that promote competition. ${ }^{132}$ He stated that it was not necessary to go as far as the majority apparently did to reach the same result in that particular case. ${ }^{133}$ Justice Blackmun's own understanding was rather clearly stated when he expressed his "skepticism" about "shaping the Rule of Reason to such a narrow last as does the majority . ..."134 Justice Blackmun went on to object to the majority's "holding that ethical norms can pass muster under the Rule of Reason only if they promote competition "135 He was worried, as was the Seventh Circuit, that that approach would not leave "enough elbowroom for realistic application of the Sherman Act to professional services." 136 Nevertheless, it does appear that Justice Blackmun so viewed the holding of a majority of the Supreme Court in Professional Engineers, and it is of very questionable propriety for a court of

126. Id. at 219.

127. Id.

128. Id at 227. On remand the district court found against the AMA, rejecting the AMA's "patient care" defense on the facts. 671 F. Supp. 1465 (N.D. Ill. 1987).

129. National Soc'y of Professional Eng'rs v. United States, 435 U.S. 679, 699-701 (1978)

(Blackmun, J., concurring).

130. 719 F.2d at 226 .

131. Id. (quoting 435 U.S. at 699-700).

132. 435 U.S. at 699.

133. Id.

134. Id. at 700.

135. Id. at 701 .

136. Id. 
appeals to rely on what is, in effect, a dissenting opinion to carve out a defense seemingly barred by a majority of the Supreme Court.

Analysis of the relevant portions of the majority opinion in Professional Engineers supports the above conclusion and reinforces the view of Justice Blackmun about the scope of the majority's reasoning. Writing for the majority, Justice Stevens specifically addressed the question of applying antitrust doctrine to the professions. He acknowledged, as stated in the wellknown "cautionary footnote in Goldfarb,"137 that "by their nature, professional services may differ significantly from other business services."138 Therefore, he recognized, "the nature of the competition in such services may vary." 39 Nevertheless, he warned against "fashioning a broad exemption under the Rule of Reason for learned professions." 140 While "[e]thical norms may serve to regulate and promote .. . competition, and thus fall within the Rule of Reason," 141 the Court expressly declined to recognize an antitrust defense "based on the assumption that competition itself is unreasonable."142 In short, the Professional Engineers Court expressly rejected the argument that a restraint on competition could be justified "on the basis of the potential threat that competition poses to the public safety and the ethics of [a] profession." 43 Justice Stevens labeled that argument as "nothing less than a frontal assault on the basic policy of the Sherman Act."144

From an analysis of the majority opinion and Justice Blackmun's opinion in Professional Engineers, it appears that the type of non-competition-enhancing defense recognized in Wilk is of questionable validity. The Supreme Court's post-Wilk decision in FTC v. Indiana Federation of Dentists ${ }^{145}$ seems to support this criticism of Wilk.

In Indiana Federation of Dentists the Supreme Court required a "countervailing pro-competitive virtue" to justify anticompetitive conduct. 146 The Indiana dentists argued that their concerted action barring provision by dentists of dental $x$-rays to insurers was supported by non-competitive quality-of-care concerns. The dentists claimed that $\mathrm{x}$-rays, by themselves, are insufficient for a full diagnosis of dental problems or for the development of a treatment regimen. Review by insurance companies of only patients' dental xrays would accordingly skew an insurance company's payment decision to the detriment of the patient. ${ }^{147}$

The Seventh Circuit had characterized the Federation's policy as a "legal, moral, and ethical policy of quality dental care, requiring that insurers

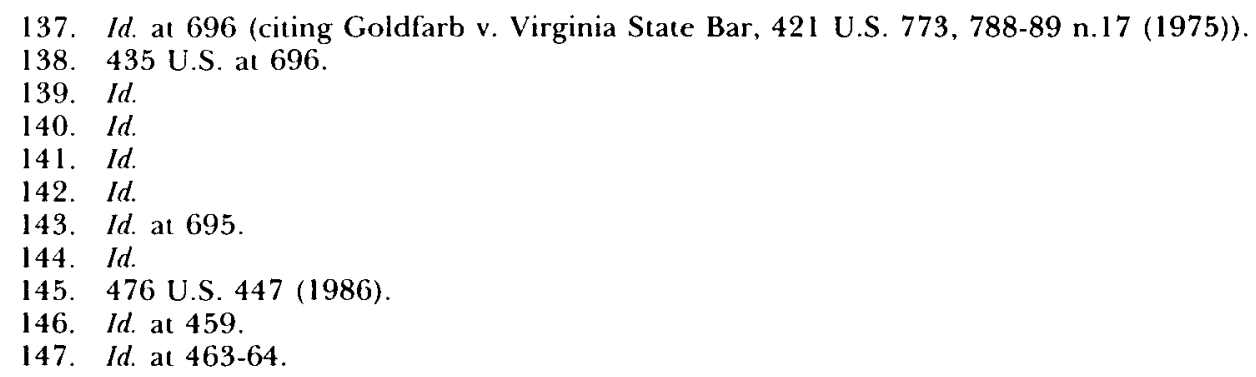


examine and review all diagnostic and clinical aids before formulating a proper course of dental treatment." 148 The Supreme Court characterized the Federation's argument as "flawed... legally."'149 Speaking unanimously through Justice White, the Court observed that the Federation's argument was premised on a fear of the unfortunate consequences of incomplete disclosure of information. Insurers sought dental x-rays. Dentists worried that consumers - their patients-would be adversely affected by disclosures of only limited information, so they refused, collectively, to disclose the partial information sought by insurers on behalf of their insureds. The Court's response to that line of argument was firm and unequivocal: "The argument is, in essence, that an unrestrained market in which consumers are given access to the information they believe to be relevant to their choices will lead them to make unwise and even dangerous choices. Such an argument amounts to 'nothing less than a frontal assault on the basic policy of the Sherman Act.',"150

Professional Engineers and International Federation of Dentists suggest that the Wilk rule of reason approach is inappropriate. Post-Wilk cases have construed the non-competitive ethical canon defense narrowly. ${ }^{151}$ We believe-and relevant Supreme Court caselaw supports that view-that hospital peer review, when viewed from an antitrust perspective, must be justified in terms of its furtherance of procompetitive policies and practices, and not in terms of other purported non-competitive rationales.

\section{B. Potential Immunity from Antitrust Liability}

Consideration of two final general issues will conclude this portion of the antitrust overview discussion: the effect of recently enacted legislation that confers limited antitrust immunity for participants in institutionalized peerreview activities; $;^{152}$ and the so-called state action (or Parker v. Brown) ${ }^{153}$ defense for peer-review activities conducted pursuant to a clearly articulated and actively supervised state policy. ${ }^{154}$

1. The Health Care Quality Improvement Act. In 1986, Congress enacted the Health Care Quality Improvement Act ("HCQIA"),155 which contained a provision that conferred limited immunity on physicians engaging in certain

148. Indiana Fed'n of Dentists v. FTC, 745 F.2d 1124, 1144 (7th Cir. 1984).

149. 476 U.S. at 463.

150. Id. (quoting National Soc'y of Professional Eng'rs v. United States, 435 U.S. 679, 695 (1978)).

151. E.g., Koefoot v. American College of Surgeons, 652 F. Supp. 882 (N.D. Ill. 1987). See also Kreuzer v. American Academy of Periodontology, 735 F.2d 1479, 1494 (D.C. Cir. 1984).

152. The immunity provisions of the Health Care Quality Improvement Act of 1986 are effective as to state laws in 1989. 42 U.S.C. $\S 11111$ (c)(1) (Supp. 1988).

153. 317 U.S. 341 (1943).

154. See, e.g., Patrick v. Burget, 108 S. Ct. 1658 (1988).

155. Pub. L. No. 99-660, 100 Stat. 3784, codified at 42 U.S.C. $\$ \$ 11101,11151$ (Supp. 1988). See generally Note, supra note 7. 
types of peer review. ${ }^{156}$ The antitrust immunity provision was part of a broader title of the omnibus bill, which was designed to improve the quality of medical care by monitoring poor quality performance. This was to occur by providing a nationwide reporting network concerning medical malpractice payments ${ }^{157}$ and by encouraging professional peer review. ${ }^{158}$ Congress was of the view that the risk of antitrust enforcement "unreasonably discourage[d] physicians from participating in effective professional peer review," 159 that the problem of poor quality of medical care could be "remedied through effective professional peer review," 160 and, therefore, that there was an "overriding national need to provide incentive and protection for physicians engaging in effective professional peer review." 161

The antitrust immunity provisions of the 1986 statute follow a pattern of past congressional action-particular circumstances in which Congress concluded that the values associated with the antitrust regime of competition may be outweighed by certain competing national goals. ${ }^{162}$ In the case of HCQIA, the limited antitrust immunity was conferred because of an overriding concern for encouraging physician participation in specified forms of peer-review activities. The congressional response to concerns about the interrelationship of peer review and antitrust suggest that the type of noncompetition-based defense recognized in Wilk is both unnecessary and inappropriate. Where a non-competition rationale is to be recognized it is appropriate for Congress and not the courts to step in. ${ }^{163}$ Following the approach specified in Professional Engineers, ${ }^{164}$ Congress, in enacting HCQIA, has established the proper and properly delimited scope of a non-competitive, quality-based antitrust defense for professional peer-review activities. 165

156. 42 U.S.C. $\$ 11111$ (a)(1) (Supp. 1988). States are permitted to opt out of the foregoing provisions. Id. $\$ 11111$ (c)(2)(B).

157. Id. $\S 11131$.

158. Id. $\$ \S 11101(3)-(5), 11111(\mathrm{a})(1), 11112(\mathrm{a})$.

159. Id. $\$ 11101(4)$.

160. Id. \$11101(3).

161. Id. $\$ 11101(5)$.

162. See National Soc'y of Professional Eng'rs v. United States, 435 U.S. 679, 690 n.14 (1978).

163. In holding the federal antitrust laws applicable to physician peer review, the Supreme Court recently acknowledged the potential tension between peer review and antitrust enforcement. The Court was "not unmindful of the policy argument that ... effective peer review is essential to the provision of quality medical care and that any threat of antitrust liability will prevent physicians from participating openly and actively in peer-review proceedings." Patrick v. Burget, 108 S. Ct. 1658, 1665 (1988). The Court recognized that Congress's enactment of HCQIA "insulated certain medical peer review activities from antitrust liability" and was a legislative response to the "concern that the possibility of antitrust liability will discourage effective peer review." Id. at 1665 n.8. For the unanimous Court, Justice Marshall observed that the antitrust laws remain fully applicable to the peer review setting "[t]o the extent that Congress has declined to exempt medical peer review" from their reach. Id. at 1665 . The policy argument favoring restrictions on antitrust doctrine in the peer review context "essentially challenges the wisdom of applying the antitrust laws to the sphere of medical care, and as such is properly directed to the legislative branch." Id. If, in the judgment of physicians, HCQIA "provides insufficient immunity to protect the peer-review process fully," then it is up to physicians or other proponents of limiting the application of antitrust doctrine in the peerreview context "to take that matter up with Congress." Id. at 1665 n. 8.

164. National Soc y of Professional Eng rs, 435 U.S. at 690.

165. See supra note 162. 
2. State Action Immunity. The Parker $v$. Brown ${ }^{166}$ state action defense is premised on the belief that the Sherman Act was not designed to bar states from imposing restraints on competition. ${ }^{167}$ Parker immunity is inferred by the courts. It assumes, on grounds of federalism, that Congress "did not intend to compromise the States' ability to regulate their domestic commerce." 168 Parker immunity extends to antitrust actions against states and state officials, ${ }^{169}$ and in proper cases, extends to suits against private parties as well. ${ }^{170}$

In California Retail Liquor Dealers Association v. Midcal Aluminum, Inc., 171 the Supreme Court established a two-part test to determine in what circumstances state regulation of private parties is immunized by Parker from coverage under the federal antitrust laws. First, the arguably anticompetitive restraint must be "one clearly articulated and affirmatively expressed as state policy." 172 Second, "the state must supervise actively any private anticompetitive conduct." 173 The active supervision requirement guards against conferral of Parker immunity to "what is essentially private anticompetitive conduct" by requiring that the state take responsibility for the private conduct. ${ }^{174}$ The active supervision requirement, therefore, is a mechanism for assuring, consistent with the federalism and state sovereignty rationales undergirding Parker immunity, that the private party is not "acting to further his own interests, rather than the governmental interests of the State."175 Thus, the "requirement of active state supervision serves essentially an evidentiary function: it is one way of ensuring that the actor is engaging in the challenged conduct pursuant to state policy." 176

The relevance of Parker immunity to institutionalized peer review stems from statutory provisions in many states requiring the maintenance by health care facilities of professional peer review. ${ }^{177}$ Under the applicable Midcal test, ${ }^{178}$ a court adjudicating an antitrust challenge to a peer-review activity

\footnotetext{
166. 317 U.S. 341 (1943).

167. See Southern Motor Carriers Rate Conference, Inc. v. United States, 471 U.S. 48, 56 (1985).

168. Id.

169. Hoover v. Ronwin, 466 U.S. 558 (1984).

170. See Southern Motor Carriers Rate Conference, 471 U.S. at 57.

171. 445 U.S. 97 (1980).

172. Id. at 105 (quoting City of Lafayette v. Louisiana Power and Light Co., 435 U.S. 389,410 (1978)).

173. Southern Motor Carriers Rate Conference, 471 U.S. at 57; see California Retail Liquor Dealers Ass'n v. Midcal Aluminum, Inc., 445 U.S. 97, 105 (1980).

174. Southern Motor Carriers Rate Conference, 471 U.S. at 57.

175. Town of Hallie v. City of Eau Claire, 471 U.S. 34, 47 (1985).

176. Id. In Patrick v. Burget, $108 \mathrm{~S}$. Ct. 1658 (1988), the Supreme Court further explained that the active supervision requirement "is designed to ensure that the state action doctrine will shelter only the particular anticompetitive acts of private parties that, in the judgment of the State, actually further state regulatory policies." Id. at 1663 . Accomplishment of that objective requires the state to "exercise ultimate control over the challenged anticompetitive conduct . . . The mere presence of some state involvement or monitoring does not suffice." $I d$. To satisfy the "active supervision" requirement, state officials must "have and exercise power to review particular anticompetitive acts of private parties and disapprove those that fail to accord with state policy." Id.

177. See, e.g., Marrese v. Interqual, Inc., 748 F.2d 373 (7th Cir. 1984).

178. See supra notes 171-73 and accompanying text.
} 
must decide whether a clearly articulated and affirmatively expressed state policy is to be found in the state laws governing professional peer review. The inquiry must address the question whether "the State as sovereign clearly intends to displace competition in a particular field with a regulatory structure."179

In addition, to confer Parker immunity a state must actively supervise the private conduct involved. ${ }^{180}$ This inquiry depends on the structure of the particular state's regulatory scheme. ${ }^{181}$ Courts must prevent anticompetitive private conduct from receiving Parker immunity merely because of "a gauzy cloak of state involvement" over what is essentially private anticompetitive conduct. ${ }^{182}$ Active supervision, even in the presence of a clearly articulated state policy, must be shown in order to satisfy a court that the actor is carrying out state policy and not pursuing its own economic self-interest. ${ }^{183}$

Although the general requirements for Parker immunity have been somewhat clarified by the Supreme Court, ${ }^{184}$ their application to specific cases is still somewhat uncertain. ${ }^{185}$ For example, in Patrick $v$. Burget, ${ }^{186}$ the Supreme Court expressly considered the scope of Parker immunity from federal antitrust liability for physicians' activities on hospital peer-review committees. Plaintiff, supported by a jury finding, alleged that defendant physicians "had initiated and participated in the hospital peer-review proceedings to reduce competition . . . rather than to improve patient care."'187 The Court of Appeals for the Ninth Circuit described the conduct as "shabby, unprincipled and unprofessional," $1 \times 8$ but held that even if the defendant doctors "had used the peer-review process to disadvantage a competitor rather than to improve patient care, their conduct . . . was immune from antitrust scrutiny" under Parker. ${ }^{189}$

179. Southern Motor Carriers Rate Conference, Inc. v. United States, 471 U.S. 48, 64 (1985). See Bolt v. Halifax Hosp. Medical Center, 851 F.2d 1273, 1281 (1 th Cir.), vacated and petition for reh $g$ en banc granted. 861 F.2d 1233 (1988), reinstated in part and vacated in part en banc, 874 F.2d 755 (11 th Cir. 1989).

180. In Patrick v. Burget, 108 S. Ct. 1658, 1663 (1988), the Supreme Court focused exclusively on the "active supervision requirement," finding it unnecessary to analyze the "clear articulation" issue in that antitrust peer-review challenge.

181. A good example of this need for fine-tuned analysis of the details of a state's regulatory structure arises from the Court of Appeals for the Seventh Circuit's decisions concerning Indiana and Illinois. With regard to Indiana, the court held that Parker immunity existed because of sufficient control of the hospital peer-review process under state law. Marrese v. Interqual, Inc. 748 F.2d 373 (7th Cir. 1984), cert. denied, 472 U.S. 1027 (1985). A contrary result obtained concerning Illinois. See Tambone v. Memorial Hosp., 825 F.2d 1132 (7th Cir. 1987).

182. California Retail Liquor Dealers Ass'n v. Medical Aluminum, Inc., 445 U.S. 97,106 (1980). See also Cantor v. Detroit Edison Co., 428 U.S. 579 (1976).

183. See Patrick v. Burget, 108 S. Ct. 1658, 1662-63 (1988).

184. See generally id.

185. See generally Bolt v. Halifax Hosp. Medical Center, 851 F.2d 1273 (11th Cir.), vacated and petition for reh'g en banc granted, 861 F.2d 1233 (11th Cir. 1988), reinstated in part and vacated in part en banc, 874 F.2d 755 (1 lih Cir. 1989).

186. 108 S. Ct. 1658 (1988).

187. Id. at 1661 .

188. Id. at 1662 n.3 (quoting Patrick v. Burget, 800 F.2d 1498, 1509 (9th Cir. 1986))

189. Id. at 1662 . 
In reversing the Ninth Circuit, the Supreme Court said it was important to limit Parker immunity to situations when the anticompetitive acts of private parties "were truly the product of state regulation." 190 The goal is "to ensure that the state action doctrine will shelter only the particular anticompetitive acts of private parties that, in the judgment of the State, actually further state regulatory policies." 191 The existence of state involvement or monitoring is insufficient. For Parker to apply, state officials must not only have "ultimate control over the challenged anticompetitive conduct" but they must also "exercise power to review particular anticompetitive acts of private parties and disapprove those that fail to accord with state policy."192 Thus, Patrick requires not only governmental authority to act but also actual governmental exercise of the authority "to determine whether" private anticompetitive "decisions comport with state regulatory policy." If private anticompetitive decisions are not in conformity with clearly articulated state regulatory policies, state officials must be empowered to and must "correct abuses." 193

Patrick's standard for satisfying the "active supervision" requirement is rigorous. It requires supervisory authority over more than the procedures involved in peer review. Ultimate control over the "actual decisions made by hospital peer-review committees" is necessary for Parker immunity. ${ }^{194}$ As Justice Marshall noted, the challenge in Patrick involved "termination of privileges itself," and not just the "procedures used to terminate hospital privileges." 195 To confer Parker immunity, a state official must both have and also exercise "ultimate authority over private privilege determinations." 196 As a result, it would appear that hospitals seeking Parker immunity would be required to forgo a good deal of their decisionmaking autonomy-a likely restraint on the wholesale seeking of Parker-immune status. ${ }^{197}$

One ambiguity in Patrick, however, may open up opportunities for broader Parker immunity. The Patrick court was faced, for the first time, with the question whether the state judiciary can provide the oversight necessary to satisfy the "active supervision" requirement. 198 It ducked the issue, concluding that the judicial review provided in that case fell "far short of satisfying the active supervision requirement" 199 because of the "very limited nature" of the review. ${ }^{200}$ At the very least, a court must review the "merits of

190. Id.

191. Id. at 1663 .

192. Id. See also Cantor v. Detroit Edison Co., 428 U.S. 579 (1976).

193. $108 \mathrm{~S}$. Ct. at 1663 .

194. Id. at 1664 .

195. Id.

196. Id.

197. The existence of HCQIA immunity will also provide some relief for participants in peerreview activity, provided that the peer review was engaged in in good faith (unlike the situation in Palrick).

198. Prior to Patrick, the Parker cases involved administrative agencies "or state supreme courts with agency-like responsibilities over the organized bar." See Bates v. State Bar, 433 U.S. 350 (1977); Patrick v. Burget, 108 S. Ct. 1658, 1664 (1988).

199. Patrick, 108 S. Ct. at 1665.

200. Id. 
a privilege termination decision to determine whether it accorded with state regulatory policy." "201

A panel of the Eleventh Circuit seized on the ambiguity of Patrick's handling of judicial oversight in Parker cases. In Bolt v. Halifax Hospital Medical Center, ${ }^{202}$ the court "perceivé[d] no principled basis for distinguishing traditional judicial review from agency review," concluding that "regulation through the judiciary may be more likely to ensure accurate implementation of the state's policy, for courts are especially well suited to divine, interpret, and enforce legislative policy." 203

The portion of the panel decision in Bolt dealing with Parker was vacated upon rehearing en banc. ${ }^{204}$ Had the panel approach been upheld and applied elsewhere, the restrictiveness of Patrick would have been eviscerated. While it is reasonable to conclude that courts can ascertain legislative intent, it is less plausible to believe that courts are well-suited to the task of exercising ultimate control, on the merits, of hospital peer-review decisions. Courts surely have no expertise in this area and are not likely to exercise the type of pro-active oversight of the substance of peer-review decisions that Patrick ostensibly requires. How much of a jolt Bolt would have caused to Patrick is unclear, but if the panel's approach should prevail in other circuits much more Parker immunity is likely to attach to the peer-review process without either congressional action ${ }^{205}$ or the kind of detailed and aggressive substantive oversight called for by Patrick. ${ }^{206}$

\section{IV \\ Application of Antitrust Doctrine to Hospital Peer-Review Activity}

As plaintiffs have sought to have antitrust doctrine applied to hospital peer-review activity, it has become clear that courts have, in general, been very wary of what they perceive to be a questionable, if not illicit, relationship. The decided cases bear all the earmarks of a judicial skepticism of the propriety of considering traditional peer review through the filter of antitrust law.207 And, if judicial and other comments one picks up are to be credited, it does appear that the number of frivolous or otherwise non-meritorious lawsuits being brought in this area is considerable.

201. Id.

202. $851 \mathrm{~F} .2 \mathrm{~d} 1273$ ( 11 th Cir.), vacated and petition for reh'g en banc granted, $861 \mathrm{~F} .2 \mathrm{~d} 1233$ (1 1 th Cir. 1988), reinslated in part and vacated in part en banc, 874 F.2d 755 (11th Cir. 1989).

203. Id. at 1282 .

204. See 874 F.2d 755 (11th Cir. 1989) (en banc).

205. Patrick v. Burget, 108 S. C. 1658,1665 n.8 (1988)

206. Id. at $1664-65$.

207. See, e.g., Kaczanowski v. Medical Center Hosp., 612 F. Supp. 688, 696-97 (D. Vt. 1985). It is at least arguable that the restrictiveness adopted by a majority of circuits in interpreting the commerce clause jurisdictional requirement for a Sherman Act claim is driven by this reluctance to expand application of the antitrust law to the staff privileges context. See, e.g., Seglin v. Esau, 769 F.2d 1274 (7th Cir. 1985). See generally supra note 85 and accompanying text. 
Concern about the inappropriate effect of antitrust on peer review led Congress to enact HCQIA, ${ }^{208}$ which was designed to improve the quality of medical practice and, to that end, to promote professional peer-review activity by physicians. ${ }^{209}$ HCQIA provides limited immunity to participants in the institutionalized peer-review process. ${ }^{210}$ The $\cdot$ congressional response seems to be in the tradition of specific, targeted exemptions from the antitrust laws where values other than competition may have a higher societal priority. ${ }^{211}$

Under traditional antitrust analysis, courts have been unwilling to balance values of competition with other social values. ${ }^{212}$ If, in limited circumstances, a value judgment is made that competition leads to undesirable consequences, specific exemptions from antitrust have been crafted by Congress to define and delimit the scope of the substitution of other values for competition. ${ }^{213}$ HCQIA thus follows in the well-trod path of other specific statutory exemptions, such as that allowing professional sports to market television rights jointly, ${ }^{214}$ which are necessitated by the refusal of courts, under the rule of reason, to weigh non-competitive social values against competition. ${ }^{215}$

HCQIA views effective peer review favorably as a tool for improving the quality of medical care, which it found to be both a "nationwide problem",216 and a "national need." 217 Congress concluded that there was an unreasonable discouragement of physicians from participating in professional peer-review activities because of the "threat of private money damage liability" under federal law, particularly the "treble damage liability under federal antitrust law." 218 Because of the desirability of improving the quality of medical care and the role of peer review in effectuating that goal, HCQIA found there to be an "overriding national need to provide incentive and protection for physicians engaging in effective professional peer review." 219

Significantly, the same legislative package that enacted HCQIA also repealed the federal health planning legislation. ${ }^{220}$ Thus, the federal health planning superstructure, which was put in place because of a congressional suspicion of competition in the health industry, ${ }^{221}$ was terminated at the same time that Congress was putting into place a limited exemption from private

208. 42 U.S.C. $\$ \$ 11101$ et seq. (Supp. 1988).

209. Id. $\$ 11101(3)$.

210 . The immunity is established by id. $\$ 11111$ (a), and the standards governing immunity are set forth in id. $\$ 11112(\mathrm{a})$.

211. See supra note 162 and accompanying text.

212. See supra p. 28 (Part III.A).

213. See Patrick v. Burget, 108 S. Ct. 1658, 1665-66 n.8 (1988); National Soc'y of Professional

Eng'rs v. United States, 435 U.S. 679, 690 n.14 (1978).

214. See 15 U.S.C. $\$ \S 1291-1295$; NCAA v. Board of Regents, 468 U.S. 85, 104 n.28 (1984).

215. See supra note 213.

216. 42 U.S.C. \$11101(3); see also id. \$11101(1).

217 . Id. $\$ 11101(2)$.

218. Id. $\$ 11101(4)$.

219. Id. $\$ 11101(5)$.

220. Pub. L. No. 99-660, 100 Stat. 3784, Section 701.

221. See generally Blumstein \& Sloan, Heallh Planning and Regulation Through Certificate of Need: An Overview, 1978 UTÄH L. REv. 3. 
damages under the antitrust law for peer review. The repeal of the federal health planning legislation makes it clear that there is no general conflict in federal policy in the health industry: The universally applicable antitrust laws, premised on the desirability of promoting competition, are to be fully applicable in the context of the health care industry, unless specifically exempted in HCQIA. ${ }^{222}$

The clear implication and contemplation, then, of the 1986 legislation is that the procompetitive approach of the antitrust laws should be generally applicable to all facets of the health care industry unless legislatively exempted. ${ }^{223}$ HCQIA provides an important but limited exemption from antitrust litigation for certain types of peer-review activity. ${ }^{224}$ For example, it does not bar federal or state governmental antitrust enforcement efforts, nor does it confer an immunity from prospective injunctive relief. ${ }^{225}$ It does not alter existing antitrust liabilities and immunities except as "specifically provided" in HCQIA. ${ }^{226}$ Implicitly, it acknowledges that the preconditions to litigation-most fundamentally the capacity to conspire-are met in the institutionalized peer-review context. Therefore, it is likely that antitrust actions will continue to be brought, although the bar against private damage awards in certain circumstances surely will be a deterrent to frivolous actions. 227

\section{A. The Capacity to Conspire: A Threshold Issue}

A threshold requirement in a section 1 Sherman Act case is the need for a plaintiff to establish the existence of a conspiracy. ${ }^{228}$ Section 1 does not apply to unilateral conduct. Action by a single firm is controlled by the dictates of section 2, not those of section 1.229 Individual conduct under section 2 scrutiny is prohibited only if it "threatens actual monopolization," 230 whereas "[c]oncerted activity subject to $\S 1$ is judged more sternly than unilateral activity under $\S 2$." 231 For a plaintiff to prevail on a section 1 claim, "it is not necessary to prove that concerted activity threatens monopolization." 232

222. See Patrick v. Burget, 108 S. Ct. 1658, 1665-66 and n.8 (1988); National Gerimedical Hosp. \& Gerontology Center v. Blue Cross of Kansas City, 452 U.S. 378 (1981); see also Calvani \& Gee, Resolving the Tension Between Health Planning and the Antitrust Laws, in Cost, Quality, and ACCEss in Hfalth Care: New Roles for Health Planning in a Competitive Environment 191 (F. Sloan, J. Blumstein \& J. Perrin eds. 1988).

223. Patrick, 108 S. Ct, at 1665 n.8.

224. See generally Havighurst, Professional Peer Review and the Antitrust Laws, 36 CASE W. RES. L. REv. $1117,1160-65(1986)$.

225. 42 U.S.C. $\$ 11111$ (a)(1) (Supp. 1988).

226. Id. $\$ 11115(\mathrm{a})$.

227. This deterrent effect may be promoted by an express fee-shifting provision in HCQIA. Id. $\$ 11113$. Since the statutory standard provides for fee-shifting only where suits are brought frivolously or in bad faith, it is unclear that the statute adds much to the pre-existing common law in this regard. See Alyeska Pipeline Service Co. v. Wilderness Soc'y, 421 U.S. 240 (1975).

228. See Copperweld Corp. v. Independence Tube Corp., 467 U.S. 752 (1984).

229. Id.

230. Id. at 767

23l. Id. at 768 .

232. Id. 
The antitrust laws regard concerted behavior more skeptically because of the greater risk of anticompetitive consequences. Concerted conduct "deprives the marketplace of the independent centers of decisionmaking that competition assumes and demands." 233 Competitors act in common concert with a potential for consequences adverse to competition overall.

In Copperweld Corp. v. Independence Tube Corp. ${ }^{234}$ the Supreme Court held that, as a matter of law, a parent corporation does not have the capacity to conspire with its wholly-owned subsidiary. The Court explicitly refrained from deciding whether, and if so under what circumstances, "a parent may be liable for conspiring with an affiliated corporation it does not completely own." 235 The rationale in Copperweld was that an internal agreement between a parent and a subsidiary does not "raise the antitrust dangers that $\S 1$ was designed to police." 236 Agreements within the corporate family do not consolidate otherwise competitive actors because "officers of a single firm are not separate economic actors pursuing separate economic interests."237 Intra-enterprise conduct, therefore, does not constitute a "sudden joining of two independent sources of economic power previously pursuing separate interests" and is thus not an "activity that warrants § 1 scrutiny." 238

Copperweld established a per se rule that elements of a single corporate enterprise do not have the legal capacity to conspire because a parent of a "wholly owned subsidiary" has a "complete unity of interest" with that subsidiary. ${ }^{239}$ This "complete unity of interest" means that " $[t]$ heir objectives are common, not disparate; their general corporate actions are guided or determined not by two separate corporate consciousnesses, but one subsidiary acts for the benefit of its parent, its sole shareholder." 240 The Copperweld per se rule is justified because the parent and the wholly-owned subsidiary "always have a 'unity of purpose or a common design'" since the parent retains "full control" if the subsidiary should not at any moment "act in the parent's bests interests." ${ }^{241}$

In sum, the per se rule announced in Copperweld, which overruled a number of intra-enterprise conspiracy cases, was justified as a faithful accommodation of antitrust doctrine to the fundamental distinction contained in the Sherman Act between unilateral and concerted conduct. The majority in Copperweld concluded that the "logic underlying Congress's decision to exempt unilateral conduct from $\S 1$ scrutiny" required formulation of a per se rule that excludes the joint conduct of a parent and its wholly owned subsidiary from section 1 coverage. ${ }^{242}$

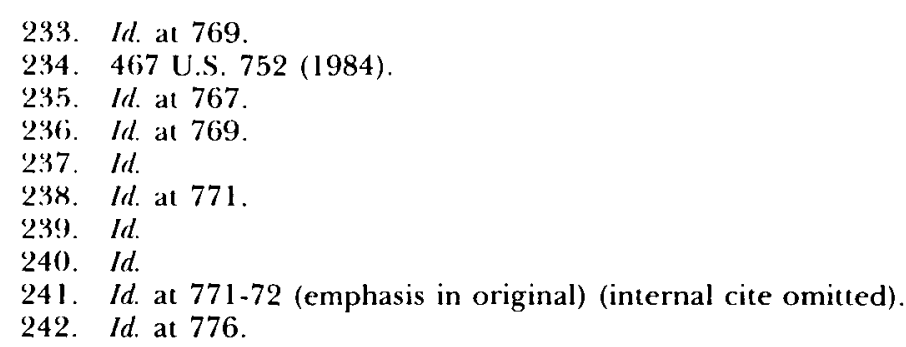


How far the Copperweld per se rule goes is unclear. In a footnote, the Court acknowledged that many courts have created an exception to the ban on intraenterprise conspiracies when corporate officers act "on their own behalf," out of an independent economic motive. ${ }^{243}$ In addition, the Court in Copperweld seemingly stressed the "complete unity of interest" between a parent and its wholly-owned subsidiary. Where control by the parent is less than complete, the question is expressly left open in Copperweld. An appropriate analysis would depend on an understanding and application of the Sherman Act rationale for treating concerted action more harshly than unilateral action. Given the reasoning of Copperweld, the inquiry would seem to turn on the existence of both a "complete unity of interest" 244 and the ability of the parent to exert "full control" 245 of the subsidiary if it acts in a manner that digresses from overall corporate interests.

Application of the analysis in Copperweld to the institutionalized peerreview process requires an understanding of the hospital as an institution and of the process of peer review. The issue of capacity to conspire arises in several contexts. First, do the peer-reviewing physicians-typically the medical staff or contracting physician groups-have the capacity to conspire? This analysis requires evaluation of a horizontal relationship. Second, is there the legal capacity for peer reviewers, either individually or collectively, to conspire with the institution itself? That determination would turn on an analysis of a vertical relationship.

We will first consider the potential for a horizontal conspiracy among peer-reviewing physicians. At the outset, one must be mindful of the Supreme Court's admonition in Copperweld that the reality rather than the form of an enterprise's structure should govern section 1 analysis. ${ }^{246} \mathrm{~A}$ business should not, out of fear of antitrust liability, be deterred from structuring its operations in the most efficient manner. ${ }^{247}$ Yet, differences in organizational structure may well reflect real differences in economic realities. This is particularly true when institutions, such as hospitals, are organized in a non-profit form. In those circumstances, enterprise objectives may be less coherent-and surely less monolithic - than when the organization is driven by a profit motive. 248 Thus, as far as hospitals are concerned, organizational form and structure may reveal a good deal about economic realities. Moreover, the influence of $\mathrm{JCAH}^{249}$ on the structure of hospitals suggests that form may have economic consequences that are relevant for antitrust analysis.

243. Id. at 770 n.15.

244. Id. at 771 .

245. Id. at 772 .

246. Id.

247. Id. at 773 .

248. See generally Hansmann, Reforming Nonprofit Corporation Law, 129 U. PA. L. REv. 497 (1981); Clark, supra note 64; Pauly \& Redisch, supra note 62.

249. See generally Jost, The Joint Commission on Accreditation of Hospitals: Private Regulation of Health Care and the Public Interest, 24 B.C. L. REv. 835 (1983). "In late 1987, the JCAH changed its name to the Joint Commission on Accreditation of Healthcare Organizations ("JCAHO'), thus reflecting its 
The initial inquiry under Copperweld is whether peer reviewers would be deemed "officers or employees of the same firm" so as not to provide the "plurality of actors imperative for a $\$ 1$ conspiracy." 250 If they fall within this category, the next question is whether an exception should be found for a peer reviewer with an independent economic stake in his own activity. ${ }^{251}$

Analysis of the "employee" issue requires a focus on different models of hospital organization. For example, an academic medical center in which fulltime faculty employees staff the hospital might come within the strict contours of the Copperweld doctrine. If the physicians were employees of the hospital or if the hospital were owned entirely by the university of which the doctors were employees, the threshold Copperweld analysis might apply. Similar status, presumably, would be accorded to full-time medical house staff officers, who are employees of the hospital. Health maintenance organization ("HMO") hospitals owned by the HMO and staffed by HMO-employed physicians might also come within the "employee" category described in Copperweld. In those circumstances, the inquiry would advance to the question whether an exception should be recognized when an independent economic stake exists on the part of peer-reviewing physicians.

Most hospital/physician relationships, however, do not reflect an employer-employee relationship. ${ }^{252}$ Physicians on the medical staff enjoy privileges to admit and treat patients in the hospital, but no employment relationship exists. ${ }^{253}$ The degree of control exercised by the hospital of its own physician staff is a matter of lively discussion. ${ }^{254}$ What does seem clear, however, is that the model of Copperweld-apparently requiring both a "complete unity of interest" between the hospital and its medical staff and the ability of the hospital to exert "full control" over the members of the medical staff if they act in a way that conflicts with overall hospital interests-is quite foreign to the realm of the conventional non-profit hospital. ${ }^{255}$ The unity-ofinterest model of the corporate world outlined in Copperweld has very little applicability to the typical JCAH non-profit hospital. ${ }^{256}$

Physicians on the medical staff practice autonomously and traditionally have steadfastly maintained their ability to bill patients directly for their professional services. ${ }^{257}$ Hospitals customarily have no role in those financial

expanding role in the accreditation of nursing homes, HMO's, home health programs, etc." C. Havighurst, Health Care Law and Policy: Readings, Notes, and Questions 509 (1988).

250. Copperweld Corp. v. Independence Tube Corp. 467 U.S. 752, 769 (1984).

251. See id. at 770 n. 15 .

252. See generally Harris, Regulation and Internal Control in Hospitals, 55 Bull. N.Y. ACAd. OF MED. 88 (1979); Harris, supra note 68.

253. See A. Southwick, The Law of Hospital and Health Care Administration 544-45 (2d ed. 1988).

254. See id. at 545-56.

255. See supra note 252.

256. For an understanding of the organizational structure of the hospital, see JoINT COMM'N ON accreditation of Hospitals, amH/88 accreditation Manual for Hospitals (1987). See generally' supra p. 14 (Part II.C).

257. The right to bill patients directly has been an important prerogative of the medical profession protected by the traditional ban on the corporate practice of medicine. For an interesting 
arrangements between doctor and patient. ${ }^{258}$ Consequently, viewing a hospital and its medical staff as analogous to the integrated corporation in Copperweld is not realistic in any theoretical, practical, or historical sense. ${ }^{259}$

This suggests, then, that the intra-enterprise shield should not, on a per se basis, shelter the peer-review activity of typical medical staff peer reviewers. This conclusion is reinforced by consideration of the Supreme Court's decision in Arizona v. Maricopa County Medical Society. ${ }^{260}$ In Maricopa County two Arizona county medical societies (Maricopa and Pima) established foundations for medical care ("FMC's") to promote fee-for-service medical practice and to provide a competitive alternative to then-existing health insurance plans. ${ }^{261}$ The FMC set maximum fee schedules for participating doctors and reviewed the necessity and appropriateness of treatment provided by participating doctors to their patients. The Court in Maricopa County had to decide whether a price-fixing conspiracy under section 1 could exist among physicians participating in each FMC.

In defense, the FMC's argued that they were not guilty of price fixing but instead should be seen as participating in an effort analogous to a joint venture among competitors. A joint venture is viewed, from a Sherman Act section 1 perspective, as a single entity. By analogy to Copperweld, participants in a joint venture are not subject to the proscriptions of section $1 .^{262}$

The majority in Maricopa County rejected the joint venture analogy, noting that each FMC was "composed of individual practitioners who compete with one another for patients."'263 By combining, the doctors sold no new product; they continued to sell medical services. In sum, "the fee agreements . . . [were] among independent competing entrepreneurs" and were thus deemed horizontal price-fixing agreements ${ }^{264}$ subject to the per se rule of illegality. The Maricopa County analysis seems applicable to the hospital peer-review context. Peer reviewers in the traditional peer-review situation are not marketing a new product and are not deriving profits from sales of a new product. ${ }^{265}$ As in the case of an FMC, peer reviewers are individual

example of the evolution of this doctrine, compare New Mexico Attorney General, Opinion No. 58167 (August 13, 1958), with New Mexico Attorney General, Opinion No. 87-39 (July 30, 1987). See generally Note, supra note 41.

258. The ostensible rationale for this limitation is that the corporation (the hospital) is engaged in the practice of medicine if it bills for the services of its independent physicians. The dangers are that a nonprofessional entity will exercise control over professional judgment, that there will be commercial exploitation of medical practice, and that physicians would have divided loyalties between their patients and the hospital. See Note, supra note 41 .

259. See supra p.14 (Part II.C).

260. 457 U.S. 332 (1982).

261. Id. at 339 .

262. Id. at 356 .

263. Id.

264. Id. at 357

265. This is not to gainsay the possibility that such an independent firm could exist and separately contract with a hospital to provide quality assurance services. Thus, for example, if a hospital were to contract with a Peer Review Organization ("PRO"), which may be composed of licensed physicians in the area, 42 U.S.C. $\$ 1320 \mathrm{C}-1$, for quality assurance standards, the PRO might satisfy the Maricopa requirements. PRO's are private organizations that contract with the federal government to provide 
practitioners in competition with one another. As in Maricopa County, the joint venture analogy seems inappropriate.

The Court of Appeals for the Third Circuit in Weiss v. York Hospital 266 faced an alleged conspiracy by the medical staff of a hospital against osteopaths ("D.O.'s"). The plaintiff claimed that he was turned down for staff privileges because of his status as a D.O., even though he was equally trained and qualified to practice medicine. ${ }^{267}$ The plaintiff alleged that the medical doctors ("M.D.'s") who exclusively controlled defendant hospital's staff were motivated by a desire to restrict competition between D.O.'s and M.D.'s, thereby allowing M.D.'s to earn higher incomes. ${ }^{268}$

\section{Judge Becker observed that the hospital's staff was composed of a}

group of doctors, all of whom practice medicine in their individual capacities, and each of whom is an independent economic entity in competition with other doctors in the . . medical community. Each staff member, therefore, has an economic interest separate from and in many cases in competition with the interests of other medical staff members. Under these circumstances, the medical staff cannot be considered a single economic entity for purposes of antitrust analysis. ${ }^{269}$

The doctors on the medical staff, thus, do not fit the Copperweld ${ }^{270}$ mold. They are not employees of a hospital with a unity of purpose. Their peer-review activity, moreover, is not akin to a joint venture because of their relationship among themselves. As the Third Circuit in Weiss properly concluded, the actions of a hospital's medical staff-under the traditional hospital structureshould be viewed as the "actions of a combination of the individual doctors who make it up." 271 This would appear to comport with the theoretical approach set out in Copperweld and Maricopa County 272 and to be consistent

utilization review and quality assurance services for the Medicare program. For a discussion of the Professional Standards Review Organizations ("PSRO") program, the predecessor of the PRO program, see Havighurst \& Blumstein, Coping with Quality/Cost Trade-Offs in Medical Care: The Role of PSROs, 70 Nw. U.L. REv. 6 (1975).

One important feature of the PRO legislation is that it requires each PRO to "make available its facilities and resources for contracting with private and public entities paying for health care in its area for review, as feasible and appropriate, of services reimbursed by such entities." 42 U.S.C. $\S 1320 \mathrm{C}-3(\mathrm{a})(11)$ (1982). Thus, PRO's are required to contract, on appropriate terms, with private medical care payers. It is at least a reasonable inference that PRO's are authorized under law to contract with non-payer institutions such as hospitals to provide peer-review, quality assurance services. In addition to satisfying the Maricopa requirements, a PRO has the advantage of its own statutory immunity from liability. See id. § 1320C-6(b). See also Kwoun v. Southeast Mo. Professional Standards Review Org., 811 F.2d 401 (8th Cir. 1987). For further elaboration on this point, see infra notes 434-35, 537, 546 and accompanying text.

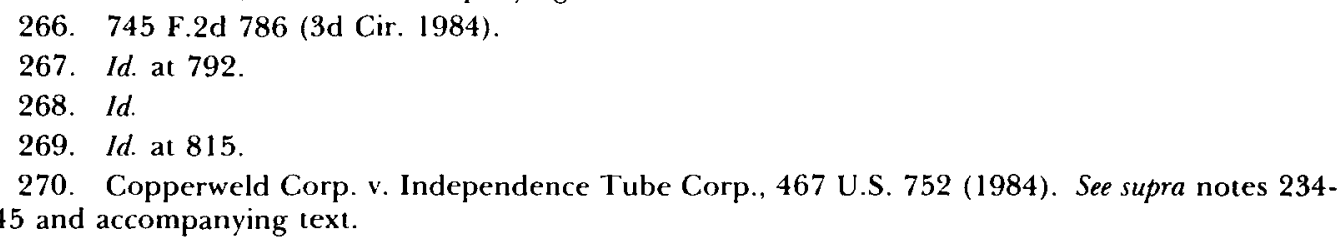

271. 745 F.2d at 816 .

272. Accord Bolt v. Halifax Hosp. Medical Center, 851 F.2d 1273 (11 th Cir.), vacated and petition for reh'g en banc granted, 861 F.2d 1233 (1988), reinstaled in part and vacated in part en banc, 874 F.2d 755 (1 lith Cir. 1989). 
with the implicit understanding of Congress when it enacted the limited peerreview immunity provisions of HCQIA. ${ }^{273}$

Another context in which hospital peer-review activities arise involves the conduct of a physician group that provides services under contract to a hospital: Consider, for example, a group that has a contractual agreement with a hospital to provide emergency room, anesthesia, pathology, or radiology services. Suppose that the group, through a form of peer review, takes an action adverse to a physician or group of physicians. Should the peer-reviewing physicians who compose that group be legally capable, under Copperweld and Maricopa County, of entering into concerted conduct under section 1? Should the contracting physician group be legally capable of conspiring with other members of the medical staff who are not members of that group?

With regard to peer-review conduct of physicians within a contracting group, the Copperweld intra-enterprise analysis would seem applicable. If the group is an economic entity with physicians serving as full-time employees, then the "plurality of actors imperative for a $\$ 1$ conspiracy" 274 would seem to be lacking. As employees of a single, unitary economic enterprise, those doctors would not be separate economic actors pursuing their own distinct economic interests.

If the group were not organized in corporate form or were otherwise not composed of employees, the outcome would turn on the Maricopa County analysis-whether the contracting group was a joint venture. In Maricopa County 275 the Supreme Court observed that a group selling a package of services for a "flat fee" would be viewed as a single economic enterprise for purposes of section 1 consideration. ${ }^{276}$ Thus, peer-review activities conducted by a group of physicians under contract to deliver services to a hospital would likely be viewed as unilateral conduct provided either that the group consisted of doctors employed by the group or that the group exhibited the characteristics of a joint enterprise as described in Maricopa County. As such a contracting entity became more amorphous in its characteristics as a single unitary enterprise and resembled more closely the federation model of autonomous independent competitive practitioners, its peer-review conduct would be more likely to become subject to section 1 scrutiny.

To the extent that a contracting group is an independent entity, or to the extent that its members are autonomous economic competitors, each would

273. The Health Care Quality Improvement Act ("HCQIA"), 42 U.S.C. $\$ \S 11101,11111-11152$ (Supp. 1988), provided limited immunity to physicians engaged in peer-review activity. A clear assumption of the legislation is that such peer-review activity satisfies the threshold section 1 requirement that a plurality of actors exist capable of conspiracy. See Copperweld Corp. v. Independence Tube Corp., 467 U.S. 752,769 (1984). It is important to recognize, however, that the finding of the existence of a "plurality of actors" capable of conspiracy is only a threshold characterization. A plaintiff must then prove the existence of a conspiracy and that the conspiracy, on the merits, constituted a violation of the substantive principles embodied in the antitrust law.

274. Copperweld Corp., 467 U.S. at 769.

275. Arizona v. Maricopa County Medical Soc'y, 457 U.S. 332 (1982).

276. Id. at 357 . 
have the legal capacity to conspire with other such economic units-for example, members of the medical staff. Consequently, if a group providing services under contract to a hospital wishes to avoid section 1 scrutiny for its peer-review conduct, it must act as a unitary entity. Since it has legal capacity to conspire with the medical staff, it must be careful not to engage in activity vis-a-vis the medical staff that can be fairly characterized as conspiratorial conduct. 277 That is, for a group to insulate its peer-review activities from section 1 review, the relationship between the physician group and the medical staff must not be susceptible to characterization as "a conscious commitment to a common schedule designed to achieve an unlawful objective." 278

In circumstances where the Copperweld threshold is satisfied-for example, a group under contract with a hospital to provide services, or a medical staff (such as at an HMO or at certain types of medical schools/centers) which is employed by the hospital ${ }^{279}$ - the applicability of the independent economic interest exception becomes relevant. ${ }^{280}$ Consider a university medical center with a medical staff employed by the hospital or by a university which wholly owns the hospital. Prima facie, Copperweld would seem to apply; however, Copperweld impliedly acknowledged that an exception to the per se rule of noncoverage which it announced might be available where corporate officers or employees were acting on their own behalf. ${ }^{281}$

In a proper case ${ }^{282}$ it would appear that the nature of medical staff interrelationships 283 would suggest the adoption of the independent economic interest exception. ${ }^{284}$ Where physician members of the employee medical staff have independent practices, the unity of interest contemplated by Copperweld just does not exist. There is no assurance that the concerns about concerted activity, as expressed in Copperweld, will not be present. ${ }^{285}$

277. See Monsanto Co. v. Spray-rite Serv. Corp., 465 U.S. 752 (1984).

278. Edward J. Sweeney \& Sons, Inc. v. Texaco, Inc., 637 F.2d 105, 111 (3d Cir. 1980), quoted approvingly in Monsanto Co., 465 U.S. at 764; see also Oltz v. St. Peter's Community Hosp., 861 F.2d 1440 (9th Cir. 1988).

279. University medical center practice plans, in which universities make available to patients on a fee-for-service basis the services of their salaried medical school faculty and retain a substantial portion of the fee-generated income, have been upheld against state law challenge. See Albany Medical College v. McShane, 66 N.Y.2d 982, 489 N.E.2d 1278, 497 N.Y.S.2d 376 (1985). Full-time HMO physicians, interestingly, have been characterized as managerial employees and thus not within the protection of the National Labor Relations Act. See Family Health Plan, Inc. v. Union of Am. Physicians and Dentists, 274 N.L.R.B. No. 168, 1985 N.L.R.B. Dec. (CCH) ๆ 17.229 (1985).

280. See Copperweld Corp., 467 U.S. at 770 n. 15.

281. Id.

282. See, e.g., Potters Medical Center v. The City Hosp. Ass'n, 800 F.2d 568 (6th Cir. 1986); infra note 323 .

283. See generally supra p. 10 (Part II).

284. The Court of Appeals for the Third Circuit in Weiss v. York Hosp., 745 F.2d 786 (3d Cir. 1984), purported to apply this exception to determine whether the hospital medical staff and its members could conspire with the hospital and thus subject their conduct to section 1 scrutiny. Id. at 817. For the reasons discussed below, it appears that the "exception" analysis as applied in Weiss was unnecessary in the context of that case, where the Copperweld threshold analysis was not satisfied in the first instance. See infra notes 308-37 and accompanying text.

285. See supra notes 234-42 and accompanying text. 
The reasons for more intensive section 1 scrutiny may be and often are likely to be present when medical staff members have an independent personal stake as competitors. ${ }^{286}$

Although sometimes thought to be in conflict with Weiss, the Sixth Circuit decision in Smith $v$. Northern Michigan Hospitals, Inc., ${ }^{287}$ properly understood, is not inconsistent with Weiss. In Smith, two hospitals merged to form Northern Michigan Hospitals, Inc. ("NMH"). NMH contracted with Burns Clinic, a multi-specialty professional corporation, to staff NMH's emergency room ("ER"). Plaintiffs alleged that the facially fair system of referring uncommitted ER patients for follow-up treatment was discriminatory in practice, favoring specialists who were members of the Burns Clinic. The court noted that such discrimination, if true, would only be actionable under the antitrust laws if the "ostensibly independent referral decisions of the emergency room physicians" were reflective of concerted action within the meaning of section 1.288

One of plaintiffs' theories was that the ER staff, all members of the Burns Clinic, "conspired with other specialists in the Burns Clinic who stood to directly benefit from the alleged improper diversion of referrals."289 At the threshold, the court noted that the ER staff, as part of the Burns Clinic, would be legally incapable of conspiring with other members of the Burns Clinic. Although Smith was decided before Copperweld, Judge Kennedy's threshold analysis in Smith comports with the Supreme Court's approach in Copperweld. Judge Kennedy noted that a finding of liability "would require approval and application of a limited independent personal stake exception to the traditional rule that a corporation cannot conspire with its officers or agents." 290 She was careful not to endorse the merits of the independent personal stake exception, but proceeded to apply the doctrinal analysis to the allegations.

Income of specialists in the Burns Clinic depended, in part, on the individual physician's billing contribution to the Clinic. ER doctors could not make self-referrals for follow-up care, so the ER physicians-"the only doctors . . . with the power to wrongfully withhold referrals-do not themselves have any personal stake in the outcome of the alleged conspiracy independent of their stake in the clinic itself." 291 Thus, the purported rationale for the allegedly improper discriminating conduct was that the ER Burns Clinic doctors were seeking to assist other members of their

286. Accord Bolt v. Halifax Hosp. Medical Center, 851 F.2d 1273, 1280 (11th Cir.), vacated and petition for reh $g$ en banc granted, 861 F.2d 1233 (11 th Cir. 1988), reinstated in part and vacated in part en banc, 874 F.2d 755 (1 l th Cir. 1989) ("[w]e perceive no basis . . for holding that the members of a medical staff are legally incapable of conspiring with one another. Each such member practices medicine in his individual capacity; each is a separate economic entity potentially in competition with other physicians.").

287. 703 F.2d 942 (6th Cir. 1983)

288. Id. at 949 .

289. Id. at 950 .

290. Id.

291. Id. at 951 . 
professional corporation through their pattern of referrals. But it makes no sense, under the rationale of Copperweld, to characterize that type of interest as an "independent personal stake." The interest allegedly being promoted by the ER doctors was precisely the kind of benign advantaging of one's colleagues (and indirectly oneself) within a unitary economic enterprise that must, under the reasoning of Copperweld, be analyzed for monopolization under section 2, not as a conspiracy under section 1 .

It would appear that Judge Kennedy's analysis in Smith would not conflict with the approach embraced by Judge Becker for the Third Circuit in Weiss. Judge Kennedy emphasized that the Burns Clinic was a group practice in which the participating physicians organized themselves into a single, unitary economic enterprise "to facilitate delivery of specialized medical services."292 There is, therefore, a joint venture in which Burns Clinic doctors sell a package of medical services. Under the analysis in Maricopa County, ${ }^{293}$ the Burns Clinic apparently involved a joint arrangement in which participating doctors were able to sell a joint product, pooling resources and sharing the "risks of loss as well as the opportunities for profit."294 Thus, treatment of the actions of the ER physicians as unitary was proper because they were acting on behalf of the unitary enterprise of which they were members, the Burns Clinic: "The interest of each clinic physician is one and the same as the enterprise of which he or she forms a part." 295

The situation in Smith is quite distinct from that in which peer reviewers participate as part of the medical staff of the hospital. As the Smith court observed, when each participating physician in an activity "maintain[s] the actual practice of their profession independent of that corporate body, . . the independent personal stake . . . is apparent."296 That, of course, is the circumstance in the case of hospital peer review. That was the point properly recognized in Weiss ${ }^{297}$ and a careful reading of the Sixth Circuit's decision in Smith indicates that its rationale is not at odds with the reasoning of Weiss.

The final issue for consideration in this section involves the tricky question whether a hospital can, within the meaning of section 1, engage in concerted action with its medical staff or with individual members of its medical staff. ${ }^{298}$

In an influential article on antitrust and hospital privileges, Professor Philip Kissam and his associates helpfully categorized hospital privileges decisions as follows: Those characterized as "physician cartels," in which "the economic interests of the medical staff would appear to be paramount

292. Id. at $951 \mathrm{n} .16$.

293. Arizona v. Maricopa County Medical Soc'y, 457 U.S. 332 (1982).

294. Id. at 356-57

295. Smith v. Northern Michigan Hosps., Inc., 703 F.2d 942, 951 n.16 (6th Cir. 1983).

296. Id.

297. See also Bolt v. Halifax Hosp. Medical Center, 851 F.2d 1273, 1280 (11th Cir.), vacated and petition for reh'g en banc granted, 861 F.2d 1233 (11th Cir. 1988), reinstated in part and vacated in part en banc, 874 F.2d 755 (11th Cir. 1989).

298. For differing approaches to this issue by the appellate courts, compare Weiss v. York Hosp., 745 F.2d 786, 817 (3d Cir. 1984), with Bolt, 851 F.2d at 1280; Oltz v. St. Peter's Community Hosp., 86I F.2d 1440, 1449-50 (9th Cir. 1988). 
and there would appear to be no legitimate interest of the hospital at stake;"' 299 those characterized as a "joint venture," in which "both the medical staff and hospital may have significant interests that are of different kinds, even though these interests support the same result;" 300 and those involving the "employer hospital" mode of decisionmaking, in which "the interest of hospital operations appears paramount and any separate anticompetitive interests of the medical staff in general are relatively weak." 301

These categories of privileges decisionmaking are analytically useful because they demonstrate the functional diversity of the relationship between the hospital and its medical staff. Kissam, Webber, Bigus, and Holzgraefe argue that a privileges decision made by an "employer hospital" might properly be deemed unilateral and therefore not within the scope of section $1,{ }^{302}$ whereas privileges decisions made by a "joint venture" or a "physician cartel" typically stem from "an agreement between independent actors who possess quite different interests." 303 That would bring such decisions within the ambit of section 1.

The Kissam, Webber, Bigus, and Holzgraefe classification paradigm strongly suggests that a functional analysis is necessary in order to secure an appropriate understanding of the relationships between a hospital and its medical staff concerning specific privileges decisions. Under Copperweld, treatment of privileges decisions as that of a single, unitary enterprise would be proper only if the participants "are not separate economic interests." $\$ 04$ To warrant consideration as a single enterprise, privileges decisions must involve both a "complete unity of interest" 305 among the participants and the ability of the hospital to "assert full control at any moment" of the medical staff if it "fails to act in the [hospital's] best interests." 306 Given the Kissam, Webber, Bigus, and Holzgraefe categories it should be clear that in someindeed most-circumstances, treatment of privileges decisions as involving a single enterprise will not be appropriate. Stated differently, in many (or most) circumstances, the hospital privileges decision will not have characteristics that warrant the exemption from section 1 accorded by Copperweld to intraenterprise conduct. Since functional relationships in the privileges setting will vary so strikingly according to the context of specific types of privileges decisions, it is inappropriate for the kind of per se exemption from section 1 coverage outlined in Copperweld ${ }^{307}$ to be applied to the hospital/medical staff relationship concerning privileges decisionmaking.

\footnotetext{
299. Kissam, Webber, Bigus \& Holzgraefe, supra note 69, at 611-12.

300. Id. at 612 .

301. Id.

302. Id. at 638 .

303. Id. at 639 .

304. Copperweld Corp. v. Independence Tube Corp., 467 U.S. 752, 769 (1984).

305. Id. at 771 .

306. Id. at $771-72$.

307. See supra notes $239-41$ and accompanying text.
} 
Despite the persuasiveness of the Kissam, Webber, Bigus, and Holzgraefe analysis as reinforced by the subsequent analysis in Copperweld, the court in the landmark Weiss decision held that, "as a matter of law," a hospital cannot enter into a vertical conspiracy with its medical staff. ${ }^{308}$ The Weiss court reasoned that the hospital delegated privileges decisions to the medical staff, which "operated as an officer of a corporation would in relation to the corporation." 309 The court seemed to rely, for its conclusion, on its finding that the medical staff, while having "independent economic interests in competition with each other," did not as an entity have an economic interest "in competition with the hospital." 310 Thus, the Third Circuit in Weiss recognized the legal capacity of the hospital's medical staff to act concertedly on a horizontal basis ${ }^{311}$ but, as a matter of law, held that a vertical agreement could not exist for purposes of section 1 analysis between a hospital and its medical staff. 312

The Third Circuit analysis in Weiss seems to be internally inconsistent. The court held that decisions of the medical staff concerning staff privileges satisfied the concerted conduct requirement of section 1.313 The court relied on cases, such as Maricopa County, ${ }^{314}$ which "reaffirm[ed] that a single entity made up of independent, competing economic entities satisfies the joint action requirement of Sherman Act, section 1."315 The court concluded that the actions of the medical staff were "the actions of a combination of the individual doctors who make it up." 316 Therefore, the staff privileges recommendations of the medical staff were "subject to scrutiny under section 1 of the Sherman Act."317

The Third Circuit's analysis and its reliance on Maricopa County make very clear the basis of its holding: "[T]he medical staff cannot be considered a single economic entity for purposes of antitrust analysis." 318 At least with respect to its analysis of the horizontal conspiracy issue, the Weiss court held

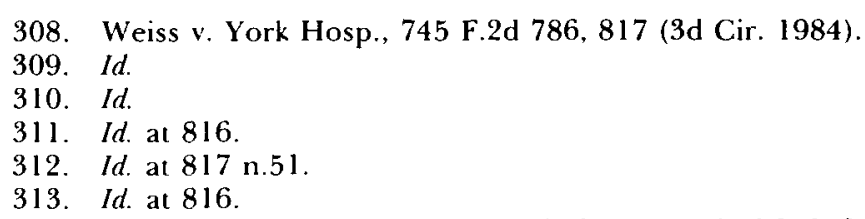

314. Arizona v. Maricopa County Medical Soc'y, 457 U.S. 332 (1982). The Third Circuit in Weiss v. York Hosp. stated that the Supreme Court in Maricopa County "simply assumed without discussion that the actions of each foundation [for medical care ("FMC")] satisfied the "contract[,] combination .. or conspiracy' element of section 1." 745 F.2d 786, 816 (3d Cir. 1984). That is a misreading of Maricopa County, which very explicitly addressed the issue and held that the entities involved would not be treated as joint ventures but rather as constituting "an agreement among hundreds of competing doctors"- that is_-"among independent competing entrepreneurs," 457 U.S. at 357. Thus, the Supreme Court in Maricopa County did not accept the FMC's as single enterprises because the combination did not permit the competitors "to sell any different product ... or . . . share the risks of loss as well as the opportunities for profit." Id. at 356. The Third Circuit in Weiss, therefore, seemed to reject any notion of a unitary enterprise that would be outside the purview of section 1 analysis. $745 \mathrm{~F} .2 \mathrm{~d}$ at $814-16$.

315. Weiss, 745 F.2d at 816.

316. Id

317. Id.

318. Id. at 815 . 
that unitary action was not present and that, therefore, Copperweld ${ }^{319}$ was inapplicable. The Weiss court did not hold that the independent personal stake exception to Copperweld ${ }^{\mathbf{3 2 0}}$ was analytically necessary to establish a section 1 case of horizontal conspiracy. ${ }^{321}$ Since there is no unity of interest among the members of the medical staff who participate in the staff privileges decisionmaking process, then the unitary enterprise analysis of Copperweld is not applicable at the threshold.

Not only do hospital staff doctors have interests that diverge from each other, but they have interests that may well be out of sync with the interests of the hospital. ${ }^{322}$ Therefore, the unitary enterprise approach of Copperweld does not fit the hospital privileges decision. If that is so, then it is analytically beside the point whether the hospital medical staff has a competitive interest with the hospital. Once the hospital privileges decisionmaking enterprise is recognized as not being unitary or integrated in character, the legal capacity for concerted action must exist between all elements-horizontal and vertical-in the process. ${ }^{323}$

Yet, the Third Circuit in Weiss held that "the hospital cannot legally conspire with its medical staff." 324 It believed that the "medical staff operate as an officer of a corporation would in relation to the corporation." 325 Even though the physicians on the hospital's medical staff were capable of

319. Copperweld Corp. v. Independence Tube Corp., 467 U.S. 752 (1984).

320. See id. at 770 n.15. The Third Circuit in Weiss quoted extensively from Copperveld. 745 F.2d at 815 n.48. It clearly concluded that the intra-enterprise theory in Copperweld was simply inapplicable to the "question of the medical staff's decision about which doctors would be allowed to practice" in the hospital. Id. at 815 n.49.

321. See 745 F.2d at 813 n.43 (expressly noting that the independent personal stake exception to Copperweld is inapplicable).

322. See supra p.14 (Part II.C). For example, physicians may order more services or extend the stay of patients for longer periods than desired by hospital administrators, who are constrained by fixed payments. In many jurisdictions, moreover, hospitals are still restricted in their exercise of control over the professional medical judgment of physicians. See generally Hall, supra note 41; Note, supra note 41 .

323. The Court of Appeals for the Sixth Circuit's decision in Potters Medical Center v. The City Hosp. Ass'n, 800 F.2d 568 (6th Cir. 1986), is distinguishable from Weiss in this regard. In Potters, a hospital was accused by another (competitor) hospital of conspiring against it. The alleged conspirators were the hospital itself, its attorney (who also was a member of the hospital's board), and a physician who served as chairman of the hospital's Department of Internal Medicine and who sat on the hospital's Executive Committee. Id at 570,572-73. The Sixth Circuit concluded that, in their challenged conduct, the two individual defendants were "undisputedly" acting as "agents of" the defendant hospital. Id. at 573. Relying on and quoting from Copperweld, the Potters court found a "unity of economic purpose" between the hospital and the individual defendants, who were acting as "officers and agents of" the defendant hospital. Id. As a result, Copperweld dictated that, "as a matter of law," the individual defendants "lack[ed] the capacity to conspire" with the defendant hospital. Id.

Given that the analysis in Copperweld applied to the challenged conduct involved, the Potters court was obliged to determine whether the independent personal stake exception to Copperweld applied. That step is unnecessary and inappropriate in a case, such as Weiss, where the underlying premise of Copperweld-that a single economic entity exists with centralized control and a "complete unity of interest," 467 U.S. at 771-72-is found to be inapplicable.

324. 745 F.2d at 815. See also id. at 817 .

325. Id. at 817 . See Pollers, 800 F.2d at 573; supra note 322 . 
conspiring, the doctors on the staff and the staff itself were incapable, as a matter of law, of conspiring with the hospital. ${ }^{326}$

This reasoning seems anomalous. Under Copperweld the reason that wholly-owned components of a corporation cannot conspire is the presence of the elements of centralized control and unity of economic interest. ${ }^{327}$ It is difficult to understand how two corporate subsidiaries could have the capacity to conspire horizontally between themselves-because they were competitors, not under the complete control of their parent corporation and not part of a unitary, integrated enterprise-but then would be unable to conspire with the parent corporation itself because of their status within the corporate hierarchy. Either there is or is not a unity of economic purpose; the analysis with respect to capacity to conspire would seem to be the same, irrespective of whether the issue is a vertical or a horizontal conspiracy. ${ }^{328}$

Under the Weiss per se rule against allowing a hospital to conspire with its medical staff, vertical agreements, instead of being substantively reviewed under the rule of reason, are categorically exempt from section 1 scrutiny. This, in effect, shields these vertical agreements from section 1 coverage-in essence a rule of per se validity. We have argued that such an approach is anomalous once the capacity for a horizontal conspiracy among members of the medical staff is recognized. We have also argued that such an approach is contrary to established doctrine under Copperweld. ${ }^{329}$ A panel of the Eleventh Circuit has found this part of Weiss' analysis to be "faulty" and has "decline[d] to embrace it." 330 Judge Tjoflat "perceive[d] no basis for holding that a hospital is legally incapable of conspiring with the members of medical staff."331 He explained that the Copperweld rule is designed to "prevent erosion of the principle that section 1 does not reach unilateral acts."332

326. Weiss v. York Hosp., 745 F.2d 786, 817 (3d Cir. 1984).

327. Copperueld Corp., 467 U.S. at 771-72.

328. It may be that a horizontal agreement among competitors is more dangerous to competition than a vertical agreement where one of the parties (the hospital) is not in competition with the alleged victims of exclusionary practices. That issue, however, is a matter for substantive doctrinal analysis. At the threshold, it is of questionable appropriateness to hold categorically that no section 1 scrutiny whatsoever applies to a vertical agreement between a hospital and its medical staff, even if the medical staff and the hospital are not competitors. Whether the agreement would be an unreasonable restraint of trade is quite a different matter. Provided that the hospital and either the medical staff or its members are separate economic entities, their conduct is not wholly unilateral. They therefore can act in concert, Copperweld Corp.. 467 U.S. at 768, subject to section 1 review: "two ... entities that previously pursued their own interests separately" would be "combining to act as one for their common benefit." Id. at 769. That is the special danger that falls within section 1. In short, "economic actors may combine for purposes of section 1 of the Sherman Act even if they are not competitors, as in the various vertical arrangements that are subject to proscription under Section 1." Quinn v. Kent Gen. Hosp., Inc., 617 F. Supp. 1226, 1243 n.16 (D. Del. 1985) (questioning the vertical conspiracy analysis of Weiss but noting the binding character of Weiss in the Third Circuit).

329. See Copperweld Corp. v. Independence Tube Corp., 467 U.S. 752 (1984).

330. See Bolt v. Halifax Hosp. Medical Center, 851 F.2d 1273, 1280 (1 1 th Cir.), vacated and petition for reh'g en banc granted, 861 F.2d 1233 (1 lth Cir. 1988), reinstated in part and vacated in part en banc, 874 F.2d 755 (11th Cir. 1989).

331. Id.

332. Id. 
The nature of a hospital is quite different because of the tradition of autonomy of the medical staff and because " $[a]$ hospital and the members of its medical staff . . . are legally separate entities." 333 There is no danger that "what is in fact unilateral activity will be bootstrapped into a 'conspiracy." ",334 In this regard, the relationship between the hospital and its medical staff stands "in contrast to a corporation and its agents." 335

Although there are other portions of the Eleventh Circuit panel's analysis in Bolt that are subject to question and have been vacated on appeal, ${ }^{336}$ its treatment of the vertical conspiracy issue is sound and should be followed. ${ }^{337}$

\section{B. Substantive Doctrine}

1. In General: Per Se versus Rule of Reason Analysis. Viewing most hospital peer-review and privileges decisions as subject to coverage under section 1 of the Sherman $\mathrm{Act}^{338}$ is, of course, only the beginning of an antitrust inquiry. ${ }^{339}$ The application of substantive doctrine to peer-review conduct requires a sensitive appreciation of the goals being promoted, the risks to competition at stake and the alternative approaches now available for quality assurance. ${ }^{340}$

Once section 1 is applicable, the most fundamental practical question is whether the rule of per se invalidity or the rule of reason will control. Under a per se approach, the practice under challenge will be deemed an unreasonable restraint of trade in violation of section 1. Courts, under a per se analysis, do not inquire elaborately into the precise nature or scope of harm or the possible business justifications for use of the contested practice. ${ }^{341}$ Per se rules save courts time and lower the plaintiffs' costs of bringing antitrust actions. They apply where, from experience, courts believe that a certain form of concerted activity has a "pernicious effect on competition and lack[s] . . any redeeming virtue." ${ }^{422}$ Because of their harsh character, per se rules are carefully targeted. Courts have been reluctant to expand the circumstances in which per se rules apply. ${ }^{343}$ Indeed, broad categories that once were thought to involve per se illegal conduct are now

333. Id. See also Kissam, Webber, Bigus \& Holzgraefe, supra note 69, at 639-40. But see Weiss v. York Hosp., 745 F.2d 786, 817, n.51 (3d Cir. 1984).

334. 851 F.2d at 1280.

335. Id. Accord Oltz v. St. Peter's Community Hosp., 861 F.2d 1440, 1449-50 (9th Cir. 1988).

336. 851 F.2d at 1281-84 (concerning immunity under Parker v. Brown, 317 U.S. 341 (1943)), reinstated in part and vacated in part en banc, 874 F.2d 755 (1 lth Cir. 1989).

337. See Oltz, 861 F.2d at 1449; Quinn v. Kent Gen. Hosp., Inc., 617 F. Supp. 1226, 1243 n. 16 (D. Del. 1985).

338. 15 U.S.C. $\S 1$.

339. See generally FTC v. Indiana Fed'n of Dentists, 476 U.S. 447 (1986).

340. See generally Jost, The Necessary and Proper Role of Regulation to Assure the Quality of Health Care, 25 Houston L. Rev. 525 (1988).

341. See United States v. Topco Assocs., Inc., 405 U.S. 596, 607 (1972). See also National Soc'y of Professional Eng'rs v. United States, 435 U.S. 679, 692 (1978).

342. Northern Pac. R. Co. v. United States, 356 U.S. 1, 5 (1958).

343. See Indiana Fed'n of Dentists, 476 U.S. at 457-59. 
recognized by the courts as not being a "unitary phenomenon"344 but requiring further analytical refinement. ${ }^{345}$

Practices subject to section 1 analysis but not falling within a per se category are scrutinized under the rule of reason, under which the "test of legality is whether the restraint imposed is such as merely regulates and perhaps thereby promotes competition or whether it is such as may suppress or even destroy competition." 346 Under the rule of reason, the court must determine whether the consequences of the contested concerted conduct constitute contraindicated constraints on competition. This necessitates an analysis of the "competitive significance of the restraint," 347 an evaluation of the "facts peculiar to the business, the history of the restraint, and the reasons why it was imposed."'348 The ultimate inquiry is whether, having weighed all the facts and circumstances, a court decides, on balance, that a "restrictive practice should be prohibited as imposing an unreasonable restraint on competition." 349

Despite the ongoing significance of the distinction, the fact is that the lines of demarcation between rule of reason and per se cases have blurred significantly in recent years. Not only has the Supreme Court selectively overruled previous per se rules in certain contexts, ${ }^{350}$ and has been reluctant to expand the categories of per se analysis, ${ }^{351}$ but it has modified the ground rules of their application as well. For example, in Jefferson Parish Hospital District No. 2 v. Hyde, ${ }^{352}$ the Court adhered to the view that "certain tying arrangements pose an unacceptable risk of stifling competition and therefore are unreasonable "per se." "353 The Hyde Court found, however, that not all tying arrangements warrant per se treatment. If each product can be competitively and separately purchased in the marketplace, a seller's decision to sell the two products jointly does not unreasonably restrain economic activity in the market for either product, especially when competing sellers are able to market either the entire package or its component parts. ${ }^{354}$ Thus, the "essential characteristics of an invalid tying arrangement lie in the seller's exploitation of its control over the tying product to force the buyer into the purchase of a tied product that the buyer either did not want at all, or might have preferred to purchase elsewhere on different terms."355 Thus, tying

344. St. Paul Fire \& Marine Ins. Co. v. Barry, 438 U.S. 531 , 543 (1978) (quoting P. AreedA, Antitrust Analysis 381 (2d ed. 1974)).

345. See Northwest Wholesale Stationers, Inc. v. Pacific Stationery \& Printing Co., 472 U.S. 248, 294-95 (1985).

346. FTC v. Indiana Fed'n of Dentists, 476 U.S. 447, 458 (1986) (quoting Chicago Bd. of Trade v. United States, 246 U.S. 231,238 (1918)).

347. National Soc y of Professional Eng rs, 435 U.S. at 692.

348. Id.

349. Continental T.V., Inc. v. GTE Sylvania Inc., 433 U.S. 36,49 (1977).

350. See, e.g., id.

351. See, e.g., FTC v. Indiana Fed'n of Dentists, 476 U.S. 447 (1986).

352. 466 U.S. 2 (1984).

353. Id. at 9 .

354. Id. at 11-12.

355. Id. at 12 . 
arrangements, which had traditionally had been deemed per se illegal, are only condemned as per se illegal where the seller has market power-that is, the ability "to force a purchaser to do something that he would not do in a competitive market." 356

To determine whether tying arrangements are to be held per se illegal, thereby avoiding in-depth inquiry into "actual market conditions," 357 a court must focus on the "probability of anticompetitive consequences."358 By requiring a plaintiff to show that a substantial volume is foreclosed by the tying arrangement and that the seller has market power, Hyde diminishes to a considerable extent the simplicity of the per se approach. To prevail on a per se theory in a tying case, a plaintiff must make a considerable threshold showing. If he fails, then he must proceed under a rule of reason inquiry into the actual restraint on competition in the relevant market. Since a plaintiff must shoulder the responsibility of establishing the threshold market conditions in the markets for the tying and tied products, it is not clear what is left of the so-called per se rule against tying after Hyde. ${ }^{359}$

In Northwest Wholesale Stationers, Inc. v. Pacific Stationery E Printing Co., ${ }^{360}$ the Supreme Court faced the question of when to apply the rule of per se invalidity to a concerted refusal to deal, which traditionally has been a category of conduct deemed per se illegal. Northwest Wholesale Stationers involved a decision by a wholesale buying cooperative to expel a member, allegedly with the motive and effect of limiting the expelled member's ability to compete. ${ }^{361}$

As in Hyde, with respect to tying arrangements, the Court in Northwest Wholesale Stationers acknowledged that "certain concerted refusals to deal or group boycotts" had been "condemned as per se violations of $\S 1$ of the Sherman Act" because they are "so likely to restrict competition without any offsetting efficiency gains." 362 While acknowledging that the co-op engaged in a form of concerted conduct, the Court observed that "[e]xactly what types of activity fall within the forbidden category" of a per se violation "is . . . far from certain." 363

The Court decided not to apply a per se rule to the concerted conduct in Northwest Wholesale Stationers. It noted that wholesale purchasing co-ops are designed to increase efficiency by permitting economies-of-scale in purchasing and warehousing and by ensuring ready access to supplies that

356. Id. at 14. See id. at n.20 (noting that "[t]his type of market power has sometimes been referred to as 'leverage'").

357. Id. at 15 .

358. Id. at 16 .

359. Cf. NCAA v. Board of Regents, 468 U.S. 85, 104 n.26 (1984) ("Indeed, there is often no bright line separating per se from Rule of Reason analysis. Per se rules may require considerable inquiry into market conditions before the evidence justifies a presumption of anticompetitive conduct.").

360. 472 U.S. $284(1985)$.

361. Id. at 287 .

362. Id. at 290.

363. Id. at 294. 
might not otherwise be available on short notice. ${ }^{364}$ Such arrangements may therefore be viewed as procompetitive, "not a form of concerted activity characteristically likely to result in predominantly anticompetitive effects." 365 A wholesale purchasing co-op must establish and enforce "reasonable rules in order to function effectively." 366 Therefore, it is not fair to conclude that the "act of expulsion necessarily impl[ies] anticompetitive animus . . thereby rais[ing] a probability of anticompetitive effect." 367 Nor would it be fair to infer that the type of expulsion involved would "characteristically be likely to result in predominantly anticompetitive effects . . ."368 Only if the co-op "possesses market power or exclusive access to an element essential to effective competition" is it possible to conclude that "expulsion is virtually always likely to have an anticompetitive effect." 369

Thus, in order for concerted activity to be subject to scrutiny under the per se approach, a plaintiff "must present a threshold case that the challenged activity falls into a category likely to have predominantly anticompetitive effects." 370 Merely alleging a concerted refusal to deal is not enough to secure per se treatment because not all such conduct has the characteristics necessary for per se condemnation. In the context of expulsion from a wholesale purchasing cooperative-a horizontal association of otherwise competitive entities-a plaintiff must either show that the co-op has "market power or unique access to a business element necessary for effective competition." 371

2. Hospital Peer Review as a Vertical Restraint: The Vertical/Horizontal Distinction. In the context of hospital staff privileges, the application of antitrust analysis should be initially distinguished on the basis of whether a horizontal or a vertical agreement is involved.

As a matter of law, some courts have been unwilling to recognize the ability of hospitals to conspire with their medical staff. ${ }^{372}$ Building on reasoning advanced by Kissam, Webber, Bigus, and Holzgraefe, ${ }^{373}$ we have argued that such a per se rule of exemption from section 1 is unwarranted..$^{374}$ If a hospital and its medical staff are able to act concertedly, however, ${ }^{375}$ it would appear inappropriate to apply a rule of per se invalidity to such a

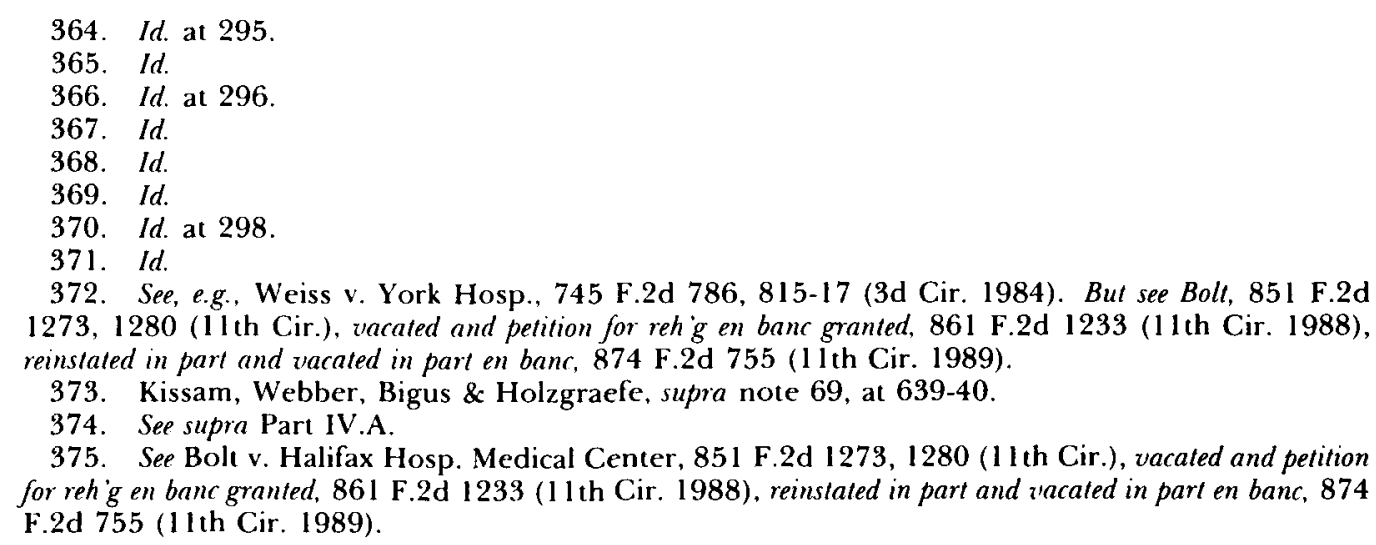


situation. As the Supreme Court stated in GTE Sylvania, ${ }^{376}$ non-price vertical restrictions often have procompetitive dimensions that warrant the more comprehensive analysis of economic impact demanded by the rule of reason. ${ }^{377}$

In the hospital privileges context, it is very likely that, much like the manufacturer in GTE Sylvania, a hospital will have legitimate independent interests that it seeks to promote in concert with its medical staff. A hospital's institutional interests must take into account its ability to compete in an increasingly competitive economic environment ${ }^{378}$ and its ability through management to reduce its ever-present potential liability for medical malpractice. ${ }^{379}$

To compete with other hospitals, a hospital must be concerned about, among other things, the quality of care that it delivers. ${ }^{380}$ The hospital has its reputation to establish and protect. Having "bad apples" on its medical staff. could easily be injurious to its reputation. ${ }^{381}$ By the same token, patients may gauge a physician's quality by, among other factors, the hospital with which he is affiliated. In this sense, doctors have a stake in keeping the bad apples out as well. Hospitals are becoming more aggressive in establishing a brandname identity with patients. ${ }^{382}$ Some hospitals now advertise that patients should contact them when they seek a physician. Doctors on the hospital's medical staff are now beginning to depend on such referrals and thus indirectly on the hospital's good name.

Hospitals may face liability for malpractice if they do not monitor the quality of medical care performed in their facilities. ${ }^{383}$ As hospitals market their services as independent entities, the trend toward the expansion of hospital liability for medical maloccurrences that take place within the hospital is likely to continue. A prudent hospital, acting in its own institutional self-interest, surely has an independent stake in monitoring the quality of its medical staff and of the services they perform. ${ }^{384}$

376. Continental T.V., Inc. v. GTE Sylvania Inc., 433 U.S. 36 (1977).

377. Id. at 54-59. The analysis in Northwest Wholesale Stationers is to like effect. Northwest Wholesale Stationers, Inc. v. Pacific Stationery \& Printing Co., 472 U.S. 284 (1985). See supra note 91 .

378. See supra p.12 (Part II.B).

379. See, e.g., Darling v. Charleston Community Memorial Hosp., 33 Ill. 2d 236, 211 N.E.2d 253 (1965), cert. denied, 383 U.S. 946 (1966); Elam v. College Park Hosp., 132 Cal. App. 3d 332, 183 Cal. Rptr. 156 (Ct. App. 1982).

380. See supra p.12 (Part 11.B). See generally Robinson v. Magovern, 52 I F. Supp. 842 (W.D. Pa. 1981), aff'd per curiam, 688 F.2d 824 (3d Cir. 1982).

381. See, e.g., Friedman v. Delaware County Memorial Hosp., 672 F. Supp. 171, 192 (E.D. Pa. 1987), aff'd per curiam, 849 F.2d 600, 603 (3d Cir. 1988).

382. For a discussion of this point, see Robinson, 521 F. Supp. 842 (W.D. Pa. 1981), aff'd per curiam, 688 F.2d 824 (3d Cir. 1982).

383. See supra note 379 .

384. See generally Johnson v. Misericordia Community Hosp., 99 Wis. 2d 708, 301 N.W.2d 156 (1981). 
For these reasons, a more detailed balancing of pro- and anticompetitive features of any hospital/medical staff vertical agreement is necessary. ${ }^{385}$

The Supreme Court in GTE Sylvania ${ }^{386}$ recognized that distinctions between vertical and horizontal restrictions may involve difficult issues of fact and definition. ${ }^{387}$ In this regard, it is important to recall that a formally vertical restriction may be the result of pressures exerted by competitors seeking to implement a horizontal group boycott through concerted action with a party in a vertical relationship to the boycotted competitor. Such arrangements are regarded as horizontal group boycotts, ${ }^{388}$ which are, under the proper circumstances, illegal per se. ${ }^{389}$

As a practical matter, both horizontal and vertical restraints exist in the typical peer-review/staff privileges context. Thus, even if a consensus could be reached concerning the criteria for determining whether a restraint were vertical in character, the issue might be of little actual significance since a plaintiff would be satisfied to pursue his remedy under the horizontal restraint theory. ${ }^{390}$ This was the case, for example, in Quinn v. Kent General Hospital, Inc. ${ }^{391}$ The distinction would matter, however, where the physicians on the staff of the hospital are institutional employees (for example, a university medical center staffed by full-time faculty or an HMO hospital staffed by HMO employee-physicians), where the defendant medical staff physicians do not seek to exclude a physician or group of physicians, ${ }^{392}$ or where the medical staff physicians can show that they were unable to effectuate their horizontal restraint, so as to affect competition adversely. ${ }^{393}$

While characterization of the staff privileges decision as horizontal or vertical is potentially of both economic and legal significance, ${ }^{394}$ there is disagreement about how courts should make this determination.

One approach would start with the presumption that decisions formally made in the name of the hospital by the medical staff are decisions of the hospital itself. Even if the hospital delegates its decisionmaking authority to the medical staff, a case could be made that it is doing so because of its perception of what is in the hospital's best interest. ${ }^{395}$

\footnotetext{
385. The thrust of this argument is that, in the face of competitive pressures, a hospital has legitimate business reasons for pursuing quality assurance goals. For a somewhat skeptical view of the effectiveness of hospital peer review as a quality assurance mechanism, see Jost, supra note 340, at 553-58. Restraints of this type between hospital and staff could then reasonably be viewed as "ancillary" rather than "naked" because they are designed, at least in part, for procompetitive purposes. For a discussion of the distinction between "naked" and "ancillary" restraints and its legal significance, see C. Havighust, supra note 249 at 325-30. See generally supra note 91.

386. Continental T.V., Inc. v. GTE Sylvania Inc., 433 U.S. 36 (1977).

387. Id. at 58 n.28.

388. See, e.g., Klor's v. Broadway-Hale Stores, Inc., 359 U.S. 207 (1959).

389. Compare id. with Northwest Wholesale Stationers, 472 U.S. 284 (1985).

390. See, e.g., Weiss v. York Hosp., 745 F.2d 786, 817 n.51 (3d Cir. 1984).

391. 617 F. Supp. 1226, 1242 (D. Del. 1985).

392. See, e.g., White v. Rockingham Radiologists, Ltd., 820 F.2d 98 (4th Cir. 1987).

393. See, e.g., Kaczanow'ski v. Medical Center Hosp., 612 F. Supp. 688, 696 (D. Vt. 1985).

394. See generally supra note 91 .

395. See Havighurst, Doctors and Hospitals: An Antitrust Perspective on Traditional Relationships, 1984 Duke. L.J. $1071,1119 \&$ n. 147.
} 
Were hospitals organized and structured as typically competitive, profitmaximizing firms, such an assumption of management control might be warranted. However, as Professor Havighurst properly points out, "the noncommercial orientation of many hospitals, the unreliability of the market forces constraining their behavior, and the record of physician dominance suggest major weaknesses in any assumption that hospital interests govern all privileges decisions."396 Indeed, the literature on hospital governance and hospital/physician power relationships strongly supports the conclusion that hospitals and their governing boards typically are controlled by their medical staffs. ${ }^{397}$ This has come about for a number of reasons, but perhaps most important have been the methods of financing hospital stays, ${ }^{398}$ the pivotal role of physicians in referring patients to hospitals, ${ }^{399}$ and the internal governance structure ${ }^{400}$ imposed on hospitals by their accrediting body (the JCAH), which requires an autonomous medical staff structure for accreditation. ${ }^{401}$ Consequently, a presumption that hospital staff privileges decisions are under the control of hospital management seems unwarranted ${ }^{402}$ because it does not take into account the industry-specific and institution-specific political and economic realities of the situation. ${ }^{403}$

In recognizing the true nature of traditional hospital decisionmaking, however, analysts must not be blind to the new developments in the hospital industry being brought about by shifts in methods for paying for in-patient care and changes in the competitive environment. Through systems of prepayment (in the case, most importantly, of Medicare) ${ }^{404}$ and negotiated charges (in the case of managed care plans), hospitals are faced with pressures to contain costs and to market themselves aggressively; thus, they are likely to behave more like traditional profit-oriented firms.

Thus, competition gives the hospital a practical reason to assert its own interest. ${ }^{405}$ If, for example, the hospital is not fully utilized and has a number of competitors, it should typically be less willing to exclude potential medical staff members who might admit appreciable numbers of patients to the hospital. ${ }^{406}$ Likewise, if the hospital competes for business on a fixed-price basis, the hospital will not be able to tolerate profligate practices on the part

\footnotetext{
396. Id. at 1120 .

397. See, e.g., Clark, supra note 64.

398. For an explanation, see, for example, Pauly, supra note 24, at 17-19.

399. See Pauly, supra note 26, at 1-15, 113-16.

400. R. Cunningham, Governing Hospitals: Trustees and the New Accountabilities 31 (2d ed. 1985) (discussing JCAH's organization in 1952 and its accreditation standards).

401. See Jost, supra note 249.

402. See Havighurst, supra note 395, at $1119-20$ \& n.147.

403. Cf. National Soc y of Professional Eng'rs, 435 U.S. at 692 (competitive effect of a restraint is "evaluated by analyzing the facts peculiar to the business, the history of the restraint, and the reasons why it was imposed").

404. See generally Iglehart, Health Policy Report: Early Experience with Prospective Payment of Hospitals, 314 New ENG. J. Med. 1460 (1986).

405. See generally Robinson v. Magovern, 521 F. Supp. 842 (W.D. Pa. 1981), aff'd per curiam, 688 F.2d 824 (3d Cir, 1982).

406. See Fuchs, The Supply of Surgeons and the Demand for Operations, 13 J. Hum. Resources 35,54 (1978).
} 
of its admitting physicians. ${ }^{407}$ The hospital will not want to keep physicians who engage in apparently wasteful behavior or who impair the reputation of the hospital. ${ }^{40}$ The hospital would resist requests from the medical staff for equipment that is not profitable to the hospital. Therefore, as the market becomes more and more competitive, hospitals increasingly become forced to act in their own institutional self interest as efficiency-maximizing organizations rather than in the interests of physicians ${ }^{409}$ or hospital managers. Competition should affect for-profit and not-for-profit hospitals in similar ways, in particular since the share of revenue that nonprofit hospitals now receive from such sources as private philanthropy and from public grants is very small. 410

As a major policy tool for promoting competition, ${ }^{411}$ the antitrust laws should be construed so as to provide an incentive for hospitals to act in accordance with the competitive model. Yet, that goal will be defeated by an excessively permissive rule for determining whether a staff privileges decision is that of the hospital itself, pursuing its institutional interests that comport with competitive objectives, or that of the medical staff, pursuing anticompetitive exclusionary or restrictive objectives.412 A formalistic approach would encourage artful subterfuge potentially leaving intact traditional power relationships and their high risk for anticompetitive conduct. ${ }^{413}$ Thus, while recognizing the desirability of encouraging hospitals to alter traditional institutional decisionmaking relationships, the law should make a hospital bear the burden of demonstrating ${ }^{414}$ substantively and functionally-and not just procedurally ${ }^{15}$-that it is behaving in an economically rational manner. The hospital's conduct should be in accordance with behavior (for example, a strategic plan) that economic theory would predict (or at least justify) for a competitive, profit-maximizing firm. ${ }^{416}$

Focusing exclusively on procedural aspects of hospital decisionmaking presents either an uncharted nightmare for a factfinder or an open invitation to facile subterfuge. ${ }^{417}$ If a hospital can use minutes of a board meeting,

407. See, e.g., Knapp v. Palos Community Hosp., 125 Ill. App. 3d 244, 465 N.E.2d 554 (1984).

408. See. e.g. Friedman v. Delaware County Memorial Hosp. 672 F. Supp. 171 (E.D. Pa. 1987), aff'd per curiam, 849 F.2d 600, 603 (3d Cir. 1988).

409. See, e.g., White v. Rockingham Radiologists, Ltd., 820 F.2d 98 (4th Cir. 1987).

410. Waldo, Levit \& Lazenby, National Health Expenditure 1985, 8 Health Care Financing Rev. 20 (Fall 1986)

411. See National Soc y of Professional Eng rs, 435 U.S. at 690-92.

412. See Havighurst, supra note 395, at $1119-20$.

413. See generally Kissam, Webber, Bigus \& Holzgraefe, supra note 69, at 640-42. See also Dolan \& Ralston, Hospital Admitting Privileges and the Sherman Act, 18 Houston L. Rev. 707, $711-12$ (1981).

414. Cf. Weiss v. York Hosp., 745 F.2d 786, 821 n.60 (3d Cir. 1984) ("where an 'ethical norm' of a learned profession is under attack on section 1 grounds, a rule of reason analysis governs [but] the defendant must demonstrate that the challenged conduct has a pro-competitive effect").

415. For a comparable approach, but in a quite different context, see Berman v. Valley Hosp., 103 N.J. 100, 510 A.2d 673 (1986); Desai v. St. Barnabas Medical Center, 103 N.J. 79, 510 A.2d 662 (1986).

416. See Havighurst, supra note 395 , at 1119 \& n.146, 1120 \& n.152.

417. See, e.g., Berman v. Valley Hosp., 103 N.J. 100, 510 A.2d 673 (1986); Desai v. St. Barnabas Medical Center, 103 N.J. 79, 510 A.2d 662 (1986). 
internal decision memoranda, and other such potentially self-serving and antiseptic factors to establish conclusively its decisionmaking predominance, then the distinction between vertical and horizontal agreements may well become analytically meaningless. ${ }^{418}$ Well-counseled hospitals will soon become expert in creating the necessary paper trail, carefully dotting the appropriate i's and crossing the appropriate t's. The vertical/horizontal inquiry will likely degenerate into a sterile formalism, devoid of substantive content. ${ }^{419}$

For a factfinding process to have substantive meaning in the context of examining hospital decisionmaking, it must be guided by a set of substantive and functional norms. More than a procedural paper chase is required.

Specifically, a hospital should be required to bear the burden of demonstrating its decisionmaking hegemony by referring to procompetitive justifications for its conduct. ${ }^{420}$ If a group of practitioners such as D.O.'s or family practitioners is excluded, the institution must demonstrate the procompetitive justification, persuading the factfinder that, from the totality of circumstances, the articulated procompetitive rationale is consistent with the overall conduct of the hospital. For example, a facility might be able to justify personnel restrictions as a marketing, image-building strategy-“our hospital only allows board-certified practitioners to use our facilities." 421 But the institution, to prevail, would have to show active promotion of that policy in other areas (for example, through aggressive quality-monitoring programs) and active pursuit of an image-building campaign (for example, through advertising or other marketing initiatives). It would have to prove, to the satisfaction of the factfinder, that it was in fact pursuing its goals as a rational economic actor and that it could justify its conduct by reference to rational, procompetitive economic principles. Without such an external objective standard of rational economic justification, the factfinding inquiry is unfocused and hopelessly ethereal. ${ }^{422}$ Given the dangers of physician

418. But see Havighurst, supra note 395 , at $1131-39$.

419. Given the likely application of the rule of reason even in most horizontal conspiracy cases, see Northwest Wholesale Stationers, Inc. v. Pacific Stationery \& Printing Co. 472 U.S. 284 (1985); Desai v. St. Barnabas Medical Center, 103 N.J. 79, 510 A.2d 662 (1986); and the subsequent adoption of the Health Care Quality Improvement Act, 42 U.S.C. $\$ \S 11101$ et seq., the concerns expressed by Professor Havighurst, see supra note 418, are likely now of lesser significance. At the time he wrote, it seemed likely that a finding of a horizontal conspiracy among the medical staff would lead to a rule of per se invalidity. See Weiss v. York Hosp., 745 F.2d 786, 820 (3d Cir. 1984). Thus, the deference Professor Havighurst recommended concerning the independent role of the hospital may have been advocated to avoid an excessively rigid rule of per se invalidity. In light of the likely application of the rule of reason to most staff privileges decisions-even when viewed as horizontal in character-the concerns he expressed about threshold characterization (i.e., vertical or horizontal) are arguably now of lesser analytical importance. How, on the horizontal merits, peerreview decisions of a hospital's medical staff should be viewed is a distinct issue. See infra p.78 (Part IV.B.5). For Professor Havighurst's approach in a later article, see Havighurst, supra note 224, at $1150-57$.

420. See, e.g., Robinson v. Magovern, 521 F. Supp. 842 (W.D. Pa. 1981), aff'd per curiam, 688 F.2d 824 (3d Cir. 1982).

421. See id.

422. The courts have examined economic theory to determine whether observed behavior constitutes an unreasonable restraint of trade. For example, in Nanavati v. Burdette Tomlin 
dominance of hospital decisionmaking, a purely procedural inquiry is insufficiently protective of core procompetitive values. As in other areas of antitrust analysis, the inquiry into purpose is relevant as an indicator of outcome. ${ }^{423}$

Hospitals can take a number of steps to increase the likelihood that a vertical and not a horizontal restraint exists. Perhaps the most important is to make it clear that medical staff decisions are, in fact, recommendations to the hospital's governing entity-that such decisions in fact as well as in theory have no independent authority. If the hospital's objective is cost containment-for example, excluding physicians who, without justification, continually exceed length-of-stay norms for their patients ${ }^{424}$ - the hospital should show that the cost-containment strategy fits into an overall business plan for controlling costs. Evidence that the governing board, perhaps

Memorial Hosp., 857 F.2d 96 (3d Cir. 1988), the Third Circuit expressed its reluctance to find anticompetitive motivation in the absence of a "rational theory of the economic gain that the [defendants] stood to receive, or of concomitant harm to competiton, from the revocation of [plaintiff's] staff privileges." Id. at 121 n.24. See also Matsushita Elec. Indus. Co. v. Zenith Radio Corp. 475 U.S. 574, 587 (1986) (where plaintiffs cannot put forward a persuasive or plausible economic theory suggesting a "rational motive to join the alleged boycott," the mere refusal to deal cannot support a finding of antitrust liability).

423. Accord Kissam, Webber, Bigus \& Holzgraefe, supra note 69, at 659-62. The HCQIA seems to accept the relevance of purpose by only immunizing peer-review activity "based on the competence or professional conduct of an individual physician ...." 42 U.S.C. $\$ 11151$ (9). The HCQIA also only immunizes conduct pursued "in the furtherance of quality health care." Id. §11112(a)(1). For a different perspective, see Havighurst, supra note 395, at 1125-26.

In Northwest Wholesale Stationers, the Supreme Court expressly stated that evidence of anticompetitive purpose is analytically relevant to a rule of reason case. Determining whether a decision is "substantially related to . . efficiency-enhancing or procompetitve purposes that otherwise justify" restrictive practices is one way of inferring "anticompetitive animus." Thus, the Supreme Court in Northwest Itholesale Stationers gave implicit endorsement to an approach that relies on conformity to or deviation from objectively determinable rational economic principles as a basis for inferring anticompetitive purpose. See Northwest Wholesale Stationers, 472 U.S. at 296 n.7.

The Court of Appeals for the Fifth Circuit has applied the reasoning of Northwest Wholesale Stationers, id., to the hospital privileges context. See Goss v. Memorial Hosp. Sys., 789 F.2d 353 (5th Cir. 1986). The plaintiff physician in Goss argued that the alleged conspirators "expelled him from the staff to drive him out of the profession and to permit some of the defendants to take over his medical practice." Id. at 355 n.3. The court found that claim relevant under the rule of reason analysis, but the Coss plaintiff conceded that "no antitrust violation under a rule of reason analysis" existed in that case. Id at 354.

Likewise, the Third Circuit has held purpose analytically relevant in a hospital staff privileges context. In Miller v. Indiana Hosp., 843 F.2d 139 (3rd Cir. 1988), the court rejected a standard of review that relied on whether a hospital that denies or revokes staff privileges lacked substantial justification for its decision. The district court had granted summary judgment for the hospital, holding that plaintiff physician "must demonstrate on the basis of the record before the hospital at the time of its decision, that the hospital lacked substantial evidence in support of its ultimate decision." Id at 142 (quoting district court). In reversing the district court, the Third Circuit concluded that a critical factual question existed: "whether the hospital's conduct in revoking [plaintiff's] staff privileges was, as the hospital claims, because of his incompetence and hence a reasonable restraint of trade or whether it was a result of anticompetitive motivation and thereby constituted a prohibited restraint of trade." Id. at 145. Thus, the Court of Appeals for the Third Circuit also has clearly recognized the importance of inquiring into the purpose underlying a hospital's conduct, and it has rejected any truncated, minimal scrutiny approach of hospital decisionmaking.

424. See, e.g., Knapp v. Palos Community Hosp., 125 Ill. App. 2d 244, 465 N.E.2d 554 (1984). 
advised by outside consultants, initiated the program would further show the vertical character of the decision. ${ }^{425}$

Similarly, a purported quality-oriented staff exclusion or circumscription of privileges should be part of an ongoing, operating, and effective qualityenhancement program. If a quality-based peer-review restraint is to be viewed credibly as vertical, the hospital must be able to demonstrate that a single decision or episode is not isolated or idiosyncratic, but rather part of a well thought out and implemented plan of quality assurance, presumably to provide high quality care to patients, to avoid malpractice liability, and to establish, maintain, or enhance a reputation in the community for high quality care. If the quality-of-care review process is halfhearted or otherwise ineffective, it is difficult to conclude that the hospital has in fact asserted its own interest.

More specifically, it would be appropriate for a factfinder to make the following types of inquiries. Does the hospital have a system in place for routine monitoring of quality of care provided within its institution? ${ }^{426}$ Is there a system in place to alert administrators in the event of frequent adverse outcomes, such as unusually high post-operative mortality rates, ${ }^{427}$ nosocomial infection rates, ${ }^{428}$ and/or hospital readmission rates? ${ }^{429}$ Or conversely, does the hospital administration rely on ad hoc reports by individual members of the medical staff and/or other hospital staff for information on adverse outcomes? ${ }^{430}$ What process is in place for pursuing adverse outcomes when they are reported? Are such reports investigated in a timely fashion? Does the hospital rely on the opinion of outside physician

425. Cf. Guerrero v. Burlington County Memorial Hosp., 70 N.J. 344, 360 A.2d 334 (1976) (upholding hospital decision to limit staff for reasons related to mission of hospital but not as a tool for promoting interests of already-existing staff physicians).

426. Following Patrick v. Burget, 108 S. Ct. 1658 (1988), there have been numerous discussions in the hospital trade press about the need for rigorous standards and procedures for quality-of-care monitoring at the level of the individual hospital. See, e.g., McCormick, Medical Staff: Peer Review in the Wake of Patrick, in Trustee 17 (July 1988).

427. On March 10,1986, responding to a Freedom of Information Act request, the Health Care Financing Administration ("HCFA"), the federal agency that administers Medicare and Medicaid, released a list of hospitals with mortality rates in 1984 that exceeded their expected mortality rate by a statistically significant amount. More recently, HCFA released a multiple volume publication giving information on mortality by hospital for 1987. Included in the publication is a response to the HCFA-published rates submitted by each hospital that wished to submit commentary. Health CARE Financing Administration, Medicare Hospital Mortality Information: 1987 (HCFA Pub. No. 00644). The usefulness of mortality as an indicator of hospital quality is assessed in detail in General Accounting Office, Medicare Improved Patient Outcome Analyses Could Enhance Quality Assessment June 1988 (GAO/PEMD-88-23), and Office of Technology Assessment, U.S. Congress, The Quality of Medical Care: Information for Consumers (OTA-H-386) June 1988 , at $71-98$.

428. For a discussion of nosocomial infection rates as a quality indicator, see OfFICE OF TeChNology Assessment, supra note 427, at 108-17.

429. There has only been limited empirical analysis of variations in hospital readmission rates. In particular, see Anderson \& Steinberg, Hospilal Readmissions in the Medicare Population, 311 New ENG. J. MEd. 1349 (1984); Anderson \& Steinberg, Predicting Hospital Readmissions in the Medicare Population, 22 Inquiry 251 (1985); Weinberg, Roos, Sola, Schori \& Jaffe, Use of Claims Data to Evaluate Health Care Outcomes: Mortality and Reoperation Following Prostatectomy, 257 J. A.M.A. 933 (1987).

430. For a critique of the effectiveness of peer review in assuring quality, see $S$. LAw \& S. Pol.AN, Pain and Profit: The Politics of Malpractice 60-64 (1978). 
experts in cases in which the quality of care rendered by an individual member of the medical staff is in question, or does the hospital exclusively rely on the opinions of physicians who compete with the physician under investigation?431 Does the medical staff collect and assess data on quality assurance, surgical case review, antibiotic use review, and other monitoring activities of this type? Are summary findings routinely reported to the hospital administration and the board?

If there are heads of clinical departments, are they selected on the basis of an extensive search, or are local doctors automatically given preference? Does the hospital monitor the performance of department heads? How are other physicians on contract selected and evaluated over time? Selection and evaluation procedures are particularly instructive when the hospital grants specific physicians the exclusive right to provide services at the hospital. In cases where exclusive contracts have been granted, who was responsible for the decisionmaking and what criteria were used? ${ }^{432}$ Can such arrangements be justified on grounds of efficiency?

Does the hospital board have a business plan containing quality-of-care objectives that can be operationalized? Does the board have the capacity to function independently of the medical staff, especially when matters involving the competence of individual physicians on the medical staff arise? What percentage of the board consists of members of the medical staff? Hospitals may invite physicians to be on the board as a means of satisfying physicians who admit many patients to the hospital. On the other hand, there are alternative mechanisms for obtaining technical information that hospital boards sometimes require. In evaluating the medical staff's recommendation to exclude a physician from the medical staff, does the board consider countervailing factors, such as the number of patients the excluded physician would admit to the hospital? ${ }^{433}$

Because of the danger to competition from horizontal restraints by members of the hospital's medical staff, a hospital seeking the relatively safe harbor of a vertical relationship to peer-review/staff privileges determinations should take steps to obtain additional sources of advice, independent of that received from the medical staff. ${ }^{434}$ For example, the hospital's governing board or administrator can seek consultation with outside experts on developing plans for quality assurance, cost control, or marketing. With specific reference to peer review, hospitals can contract with outside peer

431. To secure immunity under the HCQIA, a hospital may allow a decisionmaker to determine the merits of a staff privileges matter only if that decisionmaker (a hearing officer or a panel of individuals) is "not in direct economic competition with the physician involved." 42 U.S.C. $\S \S 11112$ (b)(3)(A)(ii), (111) (Supp. 1988).

432. See, e.g., White v. Rockingham Radiologists, Lid., 820 F.2d 98 (4th Cir. 1987); Smith v. Northern Michigan Hosps., Inc., 703 F.2d 942 (6th Cir. 1983).

433. See generally Havighurst, supra note 395 , at $1139-40$.

434. This will occur increasingly, under HCQIA, at the appeals stage. See supra note 431. It should also occur with greater frequency at earlier stages in the quality assurance process. For further elaboration of potential advantages of establishing more independence in the peer-review process, see supra note 265. 
reviewers (including PRO's) to monitor quality and to provide advice about the merits of individual physicians or groups of physicians. ${ }^{435}$

3. Hospital Peer Review as a Horizontal Restraint: The General Case. In terms of antitrust doctrine, the much tougher case analytically on the merits involves the appropriate approach to use in considering concerted conduct by the medical staff-that is, a horizontal rather than a vertical restraint. In Weiss, ${ }^{436}$ the Third Circuit found the decision by the medical staff to deny D.O.'s staff privileges subject to the rule of per se invalidity. ${ }^{437}$ Judge Becker found the actions of the medical staff, whose action satisfied the concerted activity requirement of section 1,438 "the equivalent of a concerted refusal to deal" 439 and therefore per se illegal.440

Professor Havighurst, writing before the Supreme Court's decision in Northwest Wholesale Stationers, ${ }^{41}$ has argued that viewing the denial of staff privileges as a concerted refusal to deal (and therefore illegal per se) is a fallacy. ${ }^{442}$ Havighurst would restrict the per se rule of invalidity associated with concerted refusals to deal to "naked horizontal agreements" by competitors aimed at either suppliers or customers. ${ }^{443}$ He would not apply the per se rule to a "refusal to deal by a single entity ... [e]ven if the single entity is under the control of a combination of competitors-as a hospital denying admitting privileges might be under the influence of its medical staff." "444 Havighurst advocates application of the rule of reason to refusals to deal by "lawfully constituted competitor-controlled" entities, such as a hospital medical staff, with a finding of illegality only if the refusal to deal has an "actual and impermissible adverse effect on competition." 445 This position comports with Professor Havighurst's goal of designing a legal rule that avoids extensive judicial review of or litigation concerning privileges decisions of a hospital. ${ }^{446}$

435. See supra notes $265,434$.

436. Weiss v. York Hosp., 745 F.2d 786 (3d Cir. 1984).

437. Id. at 820 .

438. Id. at 814 ("as a matter of law, the medical staff is a combination of individual doctors and therefore ... any action taken by the medical staff satisfies the 'contract, combination, or conspiracy' requirement of section 1 ").

439. Id. at 818 .

440. Id. at 820-22. The I'eiss court noted that the restraint there involved would also have violated the rule of reason. See id. at $821-22$ n.61.

441. Northwest Wholesale Stationers, Inc. v. Pacific Stationery \& Printing Co., 472 U.S. 284 (1985).

442. See Havighurst, supra note 395 , at 1104-08.

443. Id. at 1104-05.

444. Id. at 1105 .

445. Id. at 1107 .

446. See id. at $1122-23 \&$ n.160, 1125-29, 1133-39. It would appear that Professor Havighurst's goal of avoiding judicial scrutiny of a hospital's potentially anticompetitive purposes will be frustrated by the character of the immunity provided by the subsequently enacted HCQIA, which limits immunity for peer-review activity to that pursued "in the reasonable belief that the action was in furtherance of quality health care" and "in the reasonable belief that the action was warranted by the facts known ...."42 U.S.C. $\S 11112(\mathrm{a})(1),(4)$. See also id. $\$ 11151$ (9) (limiting immunity to considerations relating to the "competence or professional conduct of an individual physician"). In response to a hospital's assertion of immunity under HCQIA, a physician plaintiff will almost 
Professor Kissam and his co-authors, on the other hand, would examine privileges decisions functionally, holding those that reflect "physician cartel behavior" to be illegal per se. ${ }^{44}$ The Kissam analysis clearly influenced the Third Circuit in Weiss $\mathbf{4 4 8}$ (and, it may be said, the Congress in its enactment of HCQIA) ${ }^{449}$ The Kissam approach analogizes decisions in the physician cartel mode to a horizontal group boycott of competitors "because of their status as competitors." 450 That was, essentially, the view embraced by the Third Circuit in Weiss. ${ }^{451}$

The question for consideration is how the issue should be resolved in the privileges context in view of the Supreme Court's analysis in Northwest Wholesale Stationers. ${ }^{452}$

Under Northwest Wholesale Stationers, a plaintiff would be obliged to make a threshold showing of either "market power" or "unique access to a business element necessary for effective competition" 453 in order to prevail on a per se theory. It also appears that Northwest Wholesale Stationers allows a plaintiff, more broadly, to make out a threshold case that the "challenged activity falls into a category likely to have predominantly anticompetitive effects." 454 Whereas expulsion from a wholesale buying cooperative may not be so risky to competition as to warrant a per se rule, Northwest Wholesale Stationers seems to leave open an opportunity for a plaintiff in a hospital privileges lawsuit to make a different showing in a different context. ${ }^{455}$

The Fifth Circuit has applied Northwest Wholesale Stationers in a hospital staff privileges context. In Goss $v$. Memorial Hospital System, ${ }^{456}$ the plaintiff physician's staff privileges were suspended because of an investigation into his

certainly attempt to show that the staff privileges decision was truly made for reasons other than the physician's "competence or professional judgment." See infra note 606 and accompanying text. In this regard, HCQIA seems to embrace the significance of anticompetitive purpose as an essential ingredient in the antitrust analysis. The courts seem to have already asserted that same understanding of the law. See, e.g., Miller v. Indiana Hosp., 843 F.2d 139, 145 n.8 (3d Cir. 1988); supra note 423 .

447. Kissam, Webber, Bigus \& Holzgraefe, supra note 69, at 651-55.

448. 745 F.2d at 817 n.51. See also Miller v. Indiana Hosp., 843 F.2d 139, 144 n.6 (3d Cir. 1988).

449. See supra note 446 .

450. Kissam, Webber, Bigus \& Holzgraefe, supra note 69 , at 651.

451. See 745 F.2d at 814-16.

452. Northwest Wholesale Stationers, Inc. v. Pacific Stationery \& Printing Co., 472 U.S. 284 (1985). See generally Miller v. Indiana Hosp., 843 F.2d 139, 144 n.6 (3d Cir. 1988) (recognizing issue and leaving question unresolved); Desai v. St. Barnabas Medical Center, 102 N.J. 79, 510 A.2d 662 (1986) (holding rule of reason appropriate in context of state antitrust law in light of Northwest ITholesale Stationers).

453. Northwest I'holesale Stationers, 472 U.S. at 298.

454. Id.

455. For example, the Third Circuit has suggested that a rule of per se invalidity applies to a naked restraint, Weiss v. York Hosp., 745 F.2d 786, 820-22 nn.60, 61 (3d Cir. 1984), whereas the rule of reason applies when hospitals act on the basis of an individual's "lack of professional competence or unprofessional conduct," id. at 820. See also id. at 820-22 nn.60, 61. The distinction may, in the judgment of the Third Circuit, survive the Supreme Court's decision in Northwest Wholesale Stationers. See Miller v. Indiana Hosp., 843 F.2d 139, 144 n.6 (3d Cir. 1988); Nanavati v. Burdette Tomlin Memorial Hosp., 857 F.2d 96, 121 n.24 (3d Cir. 1988). The Third Circuit's line of demarcation is very close to the line for immunity of peer review drawn by the HCQIA legislation.See supra note 446; infra p. 78 (Part IV.B.5.a).

456. 789 F.2d 353 (5th Cir. 1986). 
competency that was triggered by a complaint. Eventually, on the basis of peer review, the plaintiff was not reappointed to the staff at the two Houston hospitals at which he held privileges. ${ }^{457}$ After plaintiff's suspension, his patients at both hospitals were assigned to other doctors.

Plaintiff alleged a conspiracy to boycott him from practicing medicine, motivated by the desire on the part of defendants to eliminate plaintiff as a competitor. ${ }^{458}$ The only issue on appeal was whether the per se or the rule of reason approach should apply.

The Fifth Circuit reviewed the proper mode of analysis in a group boycott context. It recognized that group boycotts have been held per se invalid but, relying on Northwest Wholesale Stationers, noted that "not every form of group boycott falls within the per se category." 459 By analogy to Northwest Wholesale Stationers, the Goss court found that plaintiff's expulsion from the hospital staffs through normal internal hospital peer-review procedures did "not imply anticompetitive state of mind."460 As in the case of a wholesale buying cooperative, a hospital medical staff legitimately needs some form of review procedures "to insure that hospital staff members are competent medical practitioners."461 Although plaintiff specifically alleged anticompetitive animus (that is, defendants wanted to take over his practice), following Northwest Wholesale Stationers, ${ }^{462}$ the court held that evidence of improper motive must be considered in the context of the rule of reason. ${ }^{463}$ It is the nature of the activity, not its specific factual context, that determines the structural risk to competition and therefore controls the question whether a per se rule should apply.

Once the Goss court concluded that the group conduct at issue in hospital staff privileges cases was not inherently more anticompetitive in character than the behavior under review in Northwest Wholesale Stationers, it proceeded to analyze the two factors deemed critical in Northwest Wholesale Stationers: market power and "unique access to a business element necessary for effective competition." 464 The evidence showed that, combined, the two defendant hospitals involved had fewer than 6 percent of the total available beds in Harris County and fewer than 7 percent of the total patient admissions in Harris County in the two relevant years. ${ }^{465}$ Using as a guide the Hyde 460 market power analysis of the New Orleans hospital market, the Fifth Circuit

\footnotetext{
457. Id. at 353-54.

458. Id. at 354 .

459. Id. at 355 .

460. Id.

461. Id.

462. 472 U.S. at 296 n.7.

463. 789 F.2d at 355 n.3. In Miller v. Indiana Hosp., 843 F.2d 139, 144 n.6 (3d Cir. 1988), plaintiff physician alleged anticompetitive motivation in a staff privileges context but accepted the propriety of the rule of reason standard, at least for purposes of that appeal. Thus, the Third Circuit had no occasion to decide what impact, if any, Northwest Wholesale Stationers had on Weiss v. York Hosp. 745 F.2d 786, 820-22 (3d Cir. 1984).

464. Northwest Wholesale Stationers, 472 U.S. at 298.

465. 789 F.2d at 355 .

466. See generally Jefferson Parish Hosp. Dist. No. 2 v. Hyde, 466 U.S. 2 (1984).
} 
held that the defendant hospitals did not have the market power necessary to establish a "threshold case that the alleged concerted conduct is likely to have anticompetitive effect." 467 Similarly, the court observed that there were over sixty hospitals in Harris County, and no evidence had even "tended to show" that the services offered by the two defendant hospitals were "unavailable at the other hospitals." 468 Thus, the Fifth Circuit held that the per se approach was inapplicable and concluded that the rule of reason was the proper mode of analysis.

In general, given the facts at issue, the Goss court's analysis was a faithful adherence to the principles set forth in Northwest Wholesale Stationers. The peer-review process there under challenge focused on the competence of a single individual. ${ }^{469}$ Unlike the per se group boycott cases, ${ }^{470}$ there are plausible quality-oriented, procompetitive reasons for a hospital to seek aggressively to promote quality and to weed out incompetence. ${ }^{471}$ Considerations of marketing and concern for potential malpractice liability ${ }^{472}$ are surely legitimate and serious reasons why a hospital and its medical staff would wish to establish an active peer-review process. Moreover, in many states such a peer-review process is in accordance with statutory policy, ${ }^{473}$ and it accords with the express provisions of HCQIA. ${ }^{474}$ Thus, peer review of individual physician competence is likely to have redeeming procompetitive aspects. A rule of per se invalidity in such a circumstance is not only at odds with HCQIA but is also unwarranted under evolving antitrust doctrine as expressed in Northwest Wholesale Stationers. ${ }^{475}$

4. Hospital Peer Review as a Horizontal Restraint: Specific Circumstances. If active peer review of individual physician competence is subject, as a general rule, to the rule of reason under the circumstances of Goss, ${ }^{476}$ the next questions become: (1) Are there peer-review situations (for example, involving physician cartels) that warrant per se treatment; and (2) Is per se treatment appropriate where a plaintiff can make out a threshold case, as required by

467. 789 F.2d at 355 .

468. Id.

469. Id. at 353-54.

470. See Northwest I'holesale Stationers, 472 U.S. at 295.

471. See Weiss v. York Hosp., 745 F.2d 786, 821 n.60 (3d Cir. 1984); Friedman v. Delaware County Memorial Hosp., 672 F. Supp. 171, $189-90$ (E.D. Pa. 1987), aff 'd per curiam, 849 F.2d 600, 603 (3d Cir. 1988).

472. Friedman, 672 F. Supp. at 189-90, 192.

473. See generally Patrick v. Burget, 108 S. Ct. 1658 (1988).

474. See generally supra nole 446. See 42 U.S.C. § 11101 (3).

475. It is important to reiterate the distinction drawn in Weiss between a naked restraint (in that case of M.D.'s against D.O.'s) and a restraint based on arguably procompetitive justifications. 745 F.2d at 820-22 nn.60, 61; see also Miller v. Indiana Hosp., 843 F.2d 139, 144 n.6 (3d Cir. 1988); Nanavati v. Burdette Tomlin Memorial Hosp., 857 F.2d 96, $121 \mathrm{n} .24$ (3d Cir. 1988) ("In light of the jury's finding that he was excluded because of his unprofessional behavior, [plaintiff] does not contend that the defendant's conduct would support a finding of per se liability."). See generally infra p. 78 (Part IV.B.5).

476. Goss v. Memorial Hosp. Sys., 789 F.2d 353 (5th Cir. 1986). 
Goss ${ }^{477}$ and Northwest Wholesale Stationers, ${ }^{478}$ of market power or lack of access to a facility or service necessary to enable the excluded party to compete effectively?

a. The case of physician cartel behavior. Professor Kissam and his co-authors recommended per se treatment of three types of decisions, which they categorized as examples of physician cartel decisions:479 (1) Exclusion of physicians because of their association with direct competitors of the hospital's fee-for-service medical staff (for example, HMO's, ambulatory surgical centers); (2) limitation of staff privileges to those who are members of or who agree to join existing partnerships of physicians who currently hold medical staff privileges; ${ }^{480}$ (3) restrictions on staff privileges aimed at punishing or eliminating competitors (for example, barring categories of practitioners such as osteopaths or family practitioners) ${ }^{481}$ Kissam and his co-authors view these types of situations as a form of "horizontal boycott" or a "group boycott of competitors," 482 which should be held per se illegal because they are without procompetitive justification. They view these physician cartel decisions as naked restraints, "indistinguishable from . . . cases that have held group boycotts against competitors qua competitors to be per se antitrust violations." ${ }_{483}$

Kissam, Webber, Bigus, and Holzgraefe rely, for their recommendations, on cases which ostensibly hold that concerted refusals to deal or group boycotts against competitors are illegal per se. ${ }^{484}$ These very cases were reviewed and limited by the Supreme Court in Northwest Wholesale Stationers. ${ }^{485}$ After Northwest Wholesale Stationers and Goss, it would appear that, in the absence of either market power or deprivation of access to a facility necessary to allow for effective competition, ${ }^{486}$ the three types of decision condemned by Kissam and his co-authors would be subject to the per se approach only if the challenged conduct is "likely to have predominantly anti-competitive effects" $4 \times 7$ and if the challenged practices cannot plausibly be justified as

477. Id. at $354-55$.

478. Northwest Wholesale Stationers, Inc. v. Pacific Stationery \& Printing Co., 472 U.S. 284,298 (1985).

479. Kissam, Webber, Bigus \& Holzgraefe, supra note 69, at 651-55.

480. There is an important distinction to draw on this point between exclusive contracts for certain hospital-based specialties such as pathology or radiology and a general hospital-wide requirement that staff members join existing staff groups. As Kissam, Webber, Bigus \& Holzgraefe note, "|e]xclusive privilege contracts in hospital-based specialties such as radiology may be justified by independent hospital interests, but there is no procompetitive justification for general hospitalwide exclusive privileges ...." Id. at 652. See generally Collins v. Associated Pathologists, Ltd., 844

F.2d 473 (7th Cir. 1988); White v. Rockingham Radiologists, Ltd., 820 F.2d 98 (4th Cir. 1987).

481. See, e.g. Weiss v. York Hosp., 745 F.2d 786 (3d Cir. 1984).

482. Kissam, Webber, Bigus \& Holzgraefe, supra note 69 , at 651 .

483. Id.

484. Id. at 643 \& $\mathrm{n} .227,651 \mathrm{n} .270$

485. Northwest Wholesale Stationers, Inc. v. Pacific Stationery \& Printing Co., 472 U.S. 284, 293 95 (1985).

486. See FTC v. Indiana Fed'n of Dentists, 476 U.S. 447 (1986); Hahn v. Oregon Physicians Service, 868 F.2d 1022 (9th Cir. 1989).

487. Northwest Wholesale Stationers, 472 U.S. at 298. 
"intended to enhance overall efficiency and make markets more competitive." 488

In the context of Goss, the Fifth Circuit could comfortably conclude that, in the case of peer review of an individual physician against whom a complaint challenging competency had been reviewed, the existence and implementation of peer-review procedures was necessary to assure the hospital and its staff of the quality of care delivered to patients. ${ }^{489}$ No improper "anticompetitive state of mind," 490 which would "thereby raise a probability of anticompetitive effect," 491 can reasonably be inferred from peer review in the Goss situation. ${ }^{492}$ Could such animus or effect be inferred in the areas condemned by Kissam, Webber, Bigus, and Holzgraefe, so as to warrant adoption of a per se rule?

The Supreme Court's clear backing away from per se rules, at least in the absence of market power, ${ }^{493}$ suggests that adoption of a per se rule in the situations recommended by Kissam and his co-authors is now more problematic than they argued and would depend on the ability of a hospital and its medical staff to articulate plausible justifications in terms of legitimate procompetitive objectives for the challenged conduct-that is, to establish that these are not "naked" restraints that serve "no purpose except stifling of competition." 494

One factor suggesting very careful scrutiny of the "physician cartel" decisions condemned by Kissam and his co-authors, and possible per se treatment, is the HCQIA. That Act provides for limited immunity for a "professional review action" that satisfies certain procedural requirements. ${ }^{495}$ Under HCQIA, the type of peer review involved in Goss falls within the statute's limited immunity provisions because it was "based on the competence or professional conduct of an individual physician" and related to the "health or welfare of a patient or patients." 496 However, the term "professional review action," as defined in the statute, ${ }^{497}$ does not apply to the types of decisions condemned by Kissam and his co-authors. For example, the HCQIA definition of "professional review action" specifically excludes an action that is "primarily based on . . . the physician's participation in prepaid group health plans, salaried employment, or any other manner of

\footnotetext{
488. Id. at. 294.

489. Goss v. Memorial Hosp. System, 789 F.2d 353, 355 (5th Cir. 1986).

490. Id.

491. Northuest Wholesale Stationers, 472 U.S. at 296.

492. See also Friedman v. Delaware County Memorial Hosp., 672 F. Supp. 171, 188-90 (E.D. Pa. 1987), aff'd per curiam, 849 F.2d 600, 603 (3d Cir. 1988).

493. See, e.g., FTC v. Indiana Fed'n of Dentists, 476 U.S. 447 (1986); Northwest Wholesale Stationers, 472 U.S. 284 (1985); Jefferson Parish Hosp. Dist. No. 2 v. Hyde, 466 U.S. 2 (1984).

494. White Motor Co. v. United States, 372 U.S. 253, 263 (1963). See generally Robinson v. Magovern, 521 F. Supp. 842 (W.D. Pa. 1981), aff'd per curiam, 688 F.2d 824 (3d Cir. 1982).

495. 42 U.S.C. $\S 11111$ (a)(1) (Supp. 1988). The term "professional review action" is defined at id. $\$ 11151(9)$.

496. Id. $\$ 11151(9)$.

497. See id.
} 
delivering health services whether on a fee-for-service or other basis." 498 Similarly, HCQIA excludes from the definition of a "professional review action" any action "primarily based on ... any other matter that does not relate to the competence or professional conduct of a physician."499

The legislative history of HCQIA makes it clear that protection for effective peer review was not to be extended to "actions that are really taken for anticompetitive purposes." 500 Considerable concern was expressed about abuse of peer-review processes to achieve anticompetitive objectives. ${ }^{501}$ Representative Edwards, on behalf of the Subcommittee on Civil and Constitutional Rights, noted the applicability of competitive principles in the health care industry and argued that "[w]here peer review poses the risk of preventing or discriminating against other health providers from full economic participation in the marketplace, it is no different than any other illegal restraint of trade." 502 In response, Representative Tauke stated that the scope of immunity provided in HCQIA had been narrowed over the course of several legislative drafts so that protection was given "only to quality of care motivated reviews of physicians: The limited immunity is not provided for reviews of nurses or other health professions." 503

Thus, Congress saw the need to provide limited immunity for good faith peer-review activity involving review of an individual physician's competency - that is, the situation at issue in the Goss litigation. It recognized the risk to competition if doctors reviewed non-physicians or invoked peerreview procedures for anticompetitive purposes. At the time it acted, Congress was aware of the Weiss per se rule, applied in the context of exclusion of a class of physicians (D.O.'s) from a hospital. That type of conduct was not immunized by HCQIA and seemed to be viewed as illegal by Congress.

HCQIA is powerful evidence of congressional awareness of the anticompetitive risks associated with the "physician cartel" decisions condemned by Kissam and his co-authors. One could put forward a respectable argument that HCQIA reflected a congressional decision to extend immunity for peer review to situations in which, absent the legislation, a rule of per se invalidity would apply. Yet, Supreme Court decisions before enactment of HCQIA ${ }^{504}$ reflected a softening in the Court's approach to application of per se rules. HCQIA conferred immunity, but expressly left evaluation of substantive antitrust doctrine for the courts by stating that "nothing in [HCQIA] shall be construed as changing the liabilities or

498. Id. $\$ 11151(9)(\mathrm{C})$.

499. Id. $\$ 11151(9)(\mathrm{E})$.

500. 141 Cong. Rec. H9957 (daily ed. Oct. 14, 1986) (statement of Rep. Waxman).

501. See 141 Cong. Rec. H9960 (daily ed. Oct. 14, 1986).

502. 141 Cong. Rec. H9961 (daily ed. Oct. 14, 1986) (statement of Rep. Edwards).

503. 141 Cong. Rec. H9963 (daily ed. Oct. 14, 1986) (statement of Rep. Tauke).

504. See, e.g., Northwest Wholesale Stationers, 472 U.S. 284 (1985); NCAA v. Board of Regents, 468 U.S. 85 (1984); Jefferson Parish Hosp. Dist. No. 2 v. Hyde, 466 U.S. 2 (1984). 
immunities under law." 505 Therefore, the applicability of per se rules must turn on the cases and the evolution of antitrust doctrine, not on inferences from the scope of immunity provided in HCQIA.

The automatic per se categorization recommended by Kissam, Webber, Bigus, and Holzgraefe is no longer as straightforward analytically as those authors believed because of the subsequent decisions in Indiana Federation of Dentists, Northwest Wholesale Stationers, and Hyde concerning applicability of per se rules. For a court to declare per se illegal the "physician cartel" decisions outlined by Kissam, Webber, Bigus, and Holzgraefe, it must make a finding about the inherent likeliness of anticompetitive effects and the lack of redeeming procompetitive justifications. If a court should find the case for a per se rule persuasive under those standards, however, it might draw sustenance from the legislative history and provisions of HCQIA, which could also conduce to that conclusion.

Our view is that, given Northwest Wholesale Stationers, ${ }^{506}$ a per se rule is inappropriate under these circumstances, despite the very real threat to competition posed by the restraints identified by Kissam and his coauthors. ${ }^{507}$ As we shall discuss in more detail in Part IV.B.5, we believe that the proper approach is a rebuttable presumption of invalidity under a rule of reason analysis. Such an approach allows the defendant hospital to prove, to the satisfaction of the factfinder, that legitimate procompetitive justifications outweigh the risks of adverse effects on competition in the particular context in question.

b. The case of demonstrated market power. The next question to be addressed is whether, upon a finding of market power or lack of access to a "business element necessary for effective competition," ${ }^{508}$ a court should apply a rule of per se invalidity to a decision by a hospital to deny or terminate staff privileges to a physician. This is an intriguing and most troublesome issue within the Northwest Wholesale Stationers analytical rubric because application of a per se rule does not allow for a court to consider justifications for conduct declared inherently illegal. A per se rule would, in effect, bar a hospital with market power or in control of an essential competitive resource from denying or terminating staff privileges. The rationale for the denial or termination would be irrelevant. ${ }^{509}$

505. 42 U.S.C. § 11115 (a) (Supp. 1988).

506. Northwest Wholesale Stationers, Inc. v. Pacific Stationery \& Printing Co., 472 U.S. 284 (1985). See also FTC v. Indiana Fed'n of Dentists, 476 U.S. 447 (1986) (expressing caution in expanding per se rules to professional activities in medical care context).

507. The New Jersey Supreme Court has adopted the Northwest Wholesale Stationers rationale and requires use of the rule of reason in staff privileges cases. See Desai v. St. Barnabas Medical Center, 103 N.J. 79, 97-98, 510 A.2d 662, 671-72 (1986) (construing state antitrust law). The Third Circuit has recognized the issue but left it unresolved. See Miller v. Indiana Hosp., 843 F.2d 139, 144 n.6 (3d Cir. 1988)

508. Northwest Wholesale Stationers, 472 U.S. at 298.

509. Cf. Fashion Originators' Guild of Am., Inc. v. FTC, 312 U.S. 457, 467-68 (1941) (rationale behind methods pursued in a business combination irrelevant once unlawful concerted activity is 
One approach would be to view HCQIA as a direct response to this antitrust threat to peer review. ${ }^{510}$ Very clearly, HCQIA is designed to furnish immunity from damages for hospitals and doctors participating in bona fide quality-of-care peer-review activities. ${ }^{511}$ Given the congressional commitment to effective peer review evinced in HCQIA, ${ }^{512}$ one can reasonably infer a congressional intent to confer antitrust immunity as a matter of public policy, even in the face of strong risks to competition. ${ }^{513}$ Even if such immunity, as some have argued, 514 would not have been needed in the typical rule of reason case, where antitrust courts have been reluctant to second-guess professional quality-oriented peer-review judgments, ${ }^{515}$ the immunity conferred by HCQIA would be necessary where a hospital has been shown to have market power or has control of a unique facility needed by a competitor. Northwest Wholesale Stationers, 516 which was decided well before Congress enacted HCQIA, strongly suggests that a professional peer review decision by a hospital and its medical staff, when combined with a showing of market power, would be subject to the rule of per se invalidity. ${ }^{517}$ That seems to be the implicit conclusion reached by the Fifth Circuit's analytical approach in Goss. ${ }^{518}$ HCQIA, in that view, would be a necessary legislative response to the antitrust threat to good-faith hospital peer review in those hospitals proven to possess market power or to control unique facilities needed for effective competition.

found); Klor's, Inc. v. Broadway-Hale Stores, Inc., 359 U.S. 207, $211-12$ (1959) (rationale behind group boycotts irrelevant; their mere existence is unlawful).

It is important to qualify the statement in the text by reemphasizing two points. First, the threshold requirement of combination or conspiracy is necessary. Where the hospital acts independently of its medical staff or in genuine disagreement with its medical staff, the threshold requirements may not be satisfied. See, e.g., White v. Rockingham Radiologists, Lid. 820 F.2d 98, 102 (4th Cir. 1987). Second, the per se rule derived from Northwest Itholesale Stationers applies to horizontal (not vertical) restraints, although Klor's indicates that a formal hospital decision made in agreement with and to further the interests of the medical staff would be treated as horizontal in character. See generally supra p. 56 (Part IV.B.2).

An example of the kind of staff privileges decision unlikely to trigger the rule of per se invalidity, even for market power hospitals, is a decision by the hospital justified by its own independent interests and clearly either in disagreement with or in conflict with the interests of the existing medical staff. Thus, if a hospital acts to enter into an exclusive contract with a group of physicians for the provision of hospital-based services for reasons of cost containment or quality control, that decision would not be subject to the per se rules discussed in text. Cf. White, $820 \mathrm{~F} .2 \mathrm{~d}$ at 102 (hospital rejects physician's claim for expanded privileges to interpret CT scans, despite approval by medical staff, and chooses to allow a radiology group to serve as the exclusive entity for officially interpreting all CT scans).

510. See, e.g., Patrick v. Burget, 108 S. Ct. 1658, 1665 n.8 (1988).

511. See, e.g. 42 U.S.C. $\S 11112(\mathrm{a})(1)$, (4), 11151 (9) (Supp. 1988).

512. Id. $\S \S 11101(3),(4),(5)$.

513. Id.

514. See, e.g., Havighurst, supra note 224 , at $1160-65$.

515. See, e.g., Friedman v. Delaware County Memorial Hosp., 672 F. Supp. 171 (E.D. Pa. 1977), aff 'd per curiam, 849 F.2d 600, 603 (3d Cir. 1988).

516. Northwest Wholesale Stationers, Inc. v. Pacific Stationery \& Printing Co., 472 U.S. 284 (1985).

517. This would be the case when such activities were deemed horizontal in character. See supra p. 56 (Part IV.B.2).

518. Goss v. Memorial Hosp. Sys., 789 F.2d 353 (5th Cir. 1986). 
A potential criticism of this analysis is the limited scope of HCQIA immunity. HCQIA only provides immunity for damages actions. ${ }^{519}$ Its chief sponsor, Representative Waxman, acknowledged that HCQIA did not affect "[a]ctions for reinstatement through injunctive and declaratory relief."520 Thus, if a rule of per se invalidity were applied to hospitals shown to have market power or control over unique resources needed for effective competition ("market power hospitals"), physicians disappointed with the outcome of professional review actions could seek declaratory and/or injunctive relief against a hospital or other health care entity ${ }^{521}$ to secure reinstatement. HCQIA would guard against an award of damages against the peer reviewers and the hospital in such circumstances, but it would hardly provide comprehensive protection for peer review. By protecting physicians from damage awards, it would thereby encourage their participation in the peer-review process; but, to the extent that HCQIA reflects a national policy of promoting peer review and implementation of peer-review judgments by denying or terminating privileges, it would be ineffective in the face of a per se rule-at least in the absence of some structural changes in the hospital peer-review process.

It may well be, of course, that HCQIA reflects a compromise between goals of quality assurance and protecting competition. An influential chairman of a key House of Representatives subcommittee expressed concern about the need to preserve competition in "diverse and often specialized markets." 522 This would be a particular concern in situations where hospitals were shown to have market power or control over a unique competitive resource. Thus, it would not necessarily be inappropriate to view HCQIA as compatible with a per se rule in the limited circumstances of a market power hospital. In such situations, peer review would proceed under the shield from damages provided by HCQIA, but, so long as concerted action by the medical staff-that is, a horizontal restraint-exists, ${ }^{523}$ an aggrieved physician would be able under a Northwest Wholesale Stationers ${ }^{524}$ antitrust theory of per se invalidity to sue successfully for reinstatement. ${ }^{525}$ After all, HCQIA has an express provision that states the intent that HCQIA not change existing liabilities or immunities "[e]xcept as specifically provided" by the provisions of HCQIA. ${ }^{526}$ In sum, unless some way can be found to withdraw the staff privileges decision from the Northwest Wholesale Stationers concerted-refusal-to-

519. 42 U.S.C. \$ 11111 (a)(1) (Supp. 1988).

520. 144 Cong. Rec. Hl 1589 (daily ed. Oct. 17, 1986) (statement of Rep. Waxman).

521. See 42 U.S.C. $\$ \$ 11151(4)$, (11) (Supp. 1988).

522. 141 ConG. Rec. H9961 (daily ed. Oct. 14, 1986) (letter of Rep. Edwards).

523. See supra note 509.

524. Northwest Wholesale Stationers, Inc. v. Pacific Stationery \& Printing Co., 472 U.S. 284 (1985)

525. This distinction between the unavailability of damages and the availability of injunctive relief in an antitrust action exists in actions brought against local governments. See Local Government Antitrust Act of 1984, Pub. L. No. 98-544, 98 Stat. 2750 (eliminating damage remedy but preserving right to sue for injunctive relief). See generally Sandcrest Outpatient Services, P.A. v. Cumberland County Hosp. Sys., 853 F.2d 1139 (4th Cir. 1988).

526. 42 U.S.C. $\$ 11115$ (a) (Supp. 1988). 
deal framework, it would appear that the per se rule would apply to traditional hospital peer-review activities in these specialized circumstances. The limited scope of immunity conferred by HCQIA-that is, to actions for damagesshould not alter the otherwise proper antitrust analysis.

Would this signal the death knell of peer review in market power hospitals? The clear answer is "no."

Recognition of the implications of Northwest Wholesale Stationers 527 and Goss ${ }^{528}$ in this very limited context would reflect a traditional concern for the foreclosure of access by competitors to important competitive facilities. ${ }^{529}$ Market power hospitals would continue to be able to promote quality-of-care objectives. To be successful, such hospitals would have to develop a qualityof-care, peer-review strategy that complied with antitrust doctrine. That is, those hospitals would be required to structure their quality assurance programs so as to offset the potential threats to competition posed by traditional medical staff peer-review activities. Market power hospitals would have to accommodate their quality assurance efforts to the procompetitive policies of the antitrust laws.

At one level, market power hospitals would have to seek other forms of discipline in such circumstances. Instead of excluding doctors from the hospital entirely or blanketly terminating their privileges, market power hospitals might be required to adopt less drastic approaches. For example, in cases of legitimate concern about quality, market power hospitals, in pursuit of their own institutional interests, could establish limits on the scope of

527. Northwest Wholesale Stationers, Inc. v. Pacific Stationery \& Printing Co., 472 U.S. 284 (1985).

528. Goss v. Memorial Hosp. Sys., 789 F.2d 353 (5th Cir. 1986).

529. A critical distinction under common law is drawn in some jurisdictions between physician access to staff privileges in public and private hospitals:

It is the general rule that a duly licensed physician or surgeon has a right to practice his profession in the public hospitals of the state so long as he stays within the laws and conforms to all reasonable rules and regulations of the institutions adopted for the government thereof, and he cannot be deprived of that right by rules, regulations, or actions of the hospital's governing authorities that are unreasonable, arbitrary, capricious, or discriminatory.... On the other hand, it is generally held that private hospitals have the right to exclude licensed physicians and surgeons from the use of the hospital for any cause deemed sufficient by its managing authorities.

Nashville Memorial Hosp., Inc. v. Binkley, 534 S.W.2d 318, 320 (Tenn. 1976) (citations omitted). Where public hospitals are obliged to allow physicians on staff, they are permitted to make scope-ofprivileges judgments on the basis of specific competency-based evidence. See, e.g., Armstrong v. Board of Directors of Fayette County Gen. Hosp., 553 S.W.2d 77 (Tenn. Ct. App. 1976). Some jurisdictions have expanded review of staff privileges decisions by private hospitals. New Jersey was the leading state in that development. See Greisman v. Newcomb Hosp., 40 N.J. 389, 192 A.2d 817 (1963); Berman v. Valley Hosp. 103 N.J. 100, 510 A.2d 673 (1986). See also Anton v. San Antonio Community Hosp., 19 Cal. 3d 802, 815, 567 P.2d 1162, 1168, 140 Cal. Rptr. 442, 448 (1977). Cf. Miller v. Eisenhower Medical Center, 27 Cal. 3d 614, 636-37, 614 P.2d 258, 271-72, 166 Cal. Rptr. 826,840 (1980) (Mosk, J., dissenting) (suggesting that only monopoly hospital staff privileges decisions be subject to review); Rosenberg v. Holy Redeemer Hosp., 351 Pa. Super. 399, 405-09, 506 A.2d 408, $411-13$ (1986) (same). For a recent criticism of cases that apply judicial review to staff privileges decisions of private hospitals, see Barrows v. Northwestern Memorial Hosp., 123 Ill. 2d 49, 525 N.E.2d 50 (1988). 
privileges $^{530}$ or guidelines on appropriate norms of practice. ${ }^{531}$ In problem areas, such hospitals could require oversight and monitoring of professional activities of specified physicians. ${ }^{532}$ This type of restriction-short of a boycott or a concerted refusal to deal-could well fall outside the framework established by Northwest Wholesale Stationers. ${ }^{533}$ There would be a clear qualitative rationale and, because of the use of the least anticompetitive alternative, no undue foreclosure of economic opportunity. Provided that the asserted restrictions were defensible quality-assurance mechanisms-or, in appropriate cases, cost-containment mechanisms-it is doubtful that the Northwest Wholesale Stationers per se rule would apply. ${ }^{534}$

At a more fundamental level, market power hospitals could avoid the sweep of Northwest Wholesale Stationers by altering the structure of peer-review activity. Most importantly, such hospitals could take steps to eliminate the horizontal dimension of the restraint. ${ }^{535}$ For example, as in Friedman $v$. Delaware County Memorial Hospital, ${ }^{536}$ a market power hospital could retain external professional peer reviewers. ${ }^{537}$

In Friedman, a staff physician in the pulmonary disease section of the hospital's Department of Medicine challenged the revocation of his staff privileges. The physician refused to comply with the hospital's criteria for therapeutic bronchoscopies. He was charged with overutilizing that procedure and with failure to provide follow-up documentation concerning efficacy of the procedure. ${ }^{538}$ After extensive peer-review activity by members of the hospital staff, the hospital secured a medical audit by outside experts. These specialists reviewed handling of bronchoscopy patients by the accused physician and by other staff physicians. The outside physician auditors were asked to evaluate the bronchoscopy charts, on an anonymous basis, for conformity with the hospital's criteria for performance of bronchoscopies. ${ }^{539}$ The outside audit report concluded that 60 percent of the accused physician's bronchoscopies were either "not indicated" or "probably not indicated",

530. See, e.g., Kaczanow'ski v. Medical Center Hosp., 612 F. Supp. 688, 697 (D. Vt. 1985). See also White v. Rockingham Radiologists, Ltd., 820 F.2d 98 (4th Cir. 1987); Collins v. Associated Pathologists, Ltd., 844 F.2d 473 (7th Cir. 1988).

531. See Friedman v. Delaware County Memorial Hosp., 672 F. Supp. 171, 189 (E.D. Pa. 1987), aff'd per curiam, 849 F.2d 600, 603 (3d Cir. 1988).

532. Id.

533. See Northwest Wholesale Stationers, Inc. v. Pacific Stationery \& Printing Co., 472 U.S. 284, 295 n.6 (1985).

534. The question is whether such conduct, arguably less anticompetitive than a concerted refusal to deal, would place a competitor at an unwarranted "severe competitive disadvantage." Id. See Friedman v. Delaware County Memorial Hosp., 672 F. Supp. 171 (E.D. Pa. 1987), aff 'd per curiam, 849 F.2d 600, 603 (3d Cir. 1988).

535. See supra note 509.

536. 672 F. Supp. 171 (E.D. Pa. 1987), aff 'd per curiam, 849 F.2d 600, 603 (3d Cir. 1988).

537. This, we predict, will become more and more the norm as hospitals seek the protective shelter of HCQIA immunity, which calls for peer-review judgments by persons "not in direct economic competition with the physician involved." 42 U.S.C. $\$ \$ 11112$ (b)(3)(A)(ii) \& (iii) (Supp. 1988). For further development of this theme of independent peer reviewers (and a suggestion that this function be performed by PRO's), sce supra note 265.

538. 672 F. Supp. at 178 .

539. Id. at $185-86$. 
while only 16 percent were found clearly to be "indicated."540 In addition, the Chairman of the Committee on Bronchoscopy of the American College of Chest Physicians endorsed the validity of the hospital's criteria for therapeutic bronchoscopies. 541

Use of such external peer reviewers has a number of advantages for a market power hospital in terms of avoiding antitrust liability. Any suit for reinstatement by a physician under a theory of per se antitrust invalidity would be directed against the hospital, which has the formal, legal authority to confer, deny, or revoke staff privileges. To the extent that the decision in question is the decision of the hospital itself and not part of a horizontal conspiracy among the medical staff, it would more likely be viewed as either vertical $^{542}$ or unilateral ${ }^{543}$ in character. If the decision were deemed vertical (for example, by the hospital in concert with the medical staff), the Northwest Wholesale Stationers principle of per se illegality would be inapplicable, since Northwest Wholesale Stationers applies only to horizontal restraints. ${ }^{544}$ External peer reviewers who are not competitors with members of the hospital's medical staff are not in a horizontal relationship to the physician whose privileges are in dispute. They advise the hospital. Thus, to avoid the per se illegal implications of Northwest Wholesale Stationers, a market power hospital should rely on external peer reviewers before taking definitive action in the name of quality assurance. ${ }^{545}$

There are other antitrust advantages for market power hospitals to rely on external professional peer reviewers rather than on their own medical staff. Under current law, Peer Review Organizations ("PRO's") might be authorized to perform such quality assurance services, and PRO's enjoy their own independent statutory immunity from the antitrust laws. ${ }^{546}$ Even if nonPRO external reviewers are employed, however, the employment relationship and presumed lack of competitive status with staff physicians would remove such peer-review activities from coverage under section 1 of the Sherman Act. No capacity to conspire would exist. ${ }^{547}$ Finally, to the extent that an open-

540. Id. at 186 .

541. Id. at 189. This testimony apparently was developed for trial, but it could have been done at an earlier stage as part of a process of quality review.

542. See supra note 509. See also supra p.56 (Part IV.B.2).

543. If a decision is unilateral, it does not fall within the ambit of section 1 of the Sherman Act. Copperweld Corp. v. Independence Tube Corp., 467 U.S. 752, 767-69 (1984). See supra p.39 (Part IV.A).

544. See supra note 509.

545. In emergencies, action in conformity with HCQIA could be taken in the interest of quality assurance and patient protection. Provided that the action were carried out in good faith and for reasons of quality assurance, and were otherwise in compliance with HCQIA, such peer-review activity would be immune from an award of damages. The emergency action, presumably, would be for a period of limited duration, during which time the hospital would have an opportunity to secure external reviews and pursue an appropriate procedure prior to taking definitive action. Once such steps were taken, no injunctive relief under a per se theory would be warranted.

546. See supra note 265.

547. As a matter of law, no capacity to conspire would exist in this situation, particularly since (by stipulation) these external peer reviewers would have no independent personal stake in the process. See Copperweld Corp. v. Independence Tube Corp., 467 U.S. 752, 769-70 n.15 (1984). Moreover, as 
staff arrangement for market power hospitals is deemed unsatisfactory, relief would be available through state regulatory mechanisms. State licensure boards have jurisdiction to police physician competence and can develop qualitative guidelines governing staff privileges. State regulatory authorities have the capacity to authorize hospitals and other provider institutions to establish and implement peer-review activity. Provided that the state clearly sets forth its regulatory objectives and actively supervises their implementation by public and private institutional providers, such institutional peer-review activity is immune from the federal antitrust laws. ${ }^{548}$

5. The Hospital Privileges Context: The Application of the Rule of Reason. Where hospitals have not been shown to have market power, or where hospital quality control activities can fairly be characterized as vertical in nature, professional review actions will likely be analyzed, for antitrust purposes, under the rule of reason. Under the rule of reason, the fundamental inquiry is "whether the challenged agreement is one that promotes competition or one that suppresses competition." 549 To determine whether a restraint is "unreasonably restrictive of competitive conditions," 550 a court must examine the "surrounding circumstances" to ascertain the purposes served by the challenged conduct. 551 Thus, a "factfinder weighs all of the circumstances of a case in deciding whether a restrictive practice should be prohibited as imposing an unreasonable restraint on competition." 552 In order to understand the "competitive effect" 553 of an agreement or draw an "inference or presumption" that such an agreement was "intended to restrain trade,"554 a court must analyze "the facts peculiar to the business, the history of the restraint, and the reasons why it was imposed." 555 In sum, a rule of reason inquiry must focus on the specific context in which the restraint operates to determine whether, on balance, it is "unreasonably restrictive of competitive conditions." 556

a. The case of physician cartel behavior revisited. In applying the rule of reason, courts have developed some guidelines to help give structure to the process of analysis. Courts "constantly create and revise presumptions of varying strengths to arrive at sensible decisions in the face of the many

\footnotetext{
a practical matter, it would be difficult for a disaffected physician to establish a conspiracy-even if such were possible in theory-because the plaintiff would have to demonstrate the existence of an economically plausible motivation. See Matsushita Elec. Indus. Co. v. Zenith Radio Corp., 475 U.S. 574, 587, 596-97 (1986).

548. See Patrick v. Burget, 108 S. C. 1658, 1663-66 (1988). See generally supra p.34 (Part III.B.2).

549. National Soc'y of Professional Eng'rs v. United States, 435 U.S. 679, 691 (1978).

550. Id. at 690 (quoting Standard Oil Co. v. United States, 221 U.S. 1, 58 (1911)).

551. National Soc y of Professional Eng rs, 435 U.S. at 690.

552. Continental T.V., Inc. v. GTE Sylvania Inc., 433 U.S. 36, 49 (1977).

553. National Soc y of Professional Eng'rs, 435 U.S. at 692.

554. Id. at 690 .

555. Id. at 692 .

556. Id. at 690 (quoting Standard Oil Co. v. United States, 221 U.S. 1, 58 (1911)).
} 
uncertainties of business reality." 557 Where courts have reason to believe that certain agreements are likely to have anticompetitive purposes or consequences, when viewed within the historical context of a specific industry, ${ }^{558}$ they can shift the burden of persuasion from plaintiff to defendant on specific issues.

i. A rebuttable presumption of invalidity. That a particular restraint is not deemed sufficiently harmful to competition so as to warrant establishment of a rule of per se invalidity does not necessarily foreclose the establishment of a rebuttable presumption of invalidity within a rule of reason analysis. ${ }^{559}$ Thus, in NCAA v. Board of Regents, ${ }^{560}$ the Supreme Court refused to apply the per se analysis to the NCAA's restrictive policies regarding televising of football games of member schools. The Court recognized that "the NCAA member institutions . . . created a horizontal restraint-an agreement among competitors on the way in which they will compete with one another." 561 It acknowledged that horizontal restraints of that type had "often been held to be unreasonable as a matter of law." 562 Nevertheless, the Court concluded that "it would be inappropriate to apply a per se rule" to the $N C A A$ case $\mathrm{e}^{563}$ because "horizontal restraints on competition are essential" to the very existence of intercollegiate athletics. ${ }^{564}$ Some agreements on competitive ground rules are necessary for the success of intercollegiate sports; these agreements, according to the Court, "widen consumer choice . . . and hence can be viewed as procompetitive." 565

While rejecting application of the per se rule of invalidity in $N C A A$, the Supreme Court noted that the restraint at issue in that case had a "significant potential for anticompetitive effects." 566 The Court expressly noted that Congress had "felt the need to grant professional sports an exemption from the antitrust laws for joint marketing of television rights" of the type under challenge in $N C A A{ }^{567}$ The inference the Court drew was that Congress was aware that "agreements among league members to sell television rights in a cooperative fashion could run afoul of the Sherman Act."568 Even while expressing its unwillingness to declare the NCAA television restraints illegal per se, the Court acknowledged that the "anticompetitive consequences" of the NCAA's arrangement were "apparent" because "[i]ndividual competitors lose their freedom to compete." 569 Therefore, the Court required that "some

\footnotetext{
557. P. AREEDA, supra note 96 , at ๆ 1508, at 407-08.

558. National Soc y of Professional Eng rs, 435 U.S. at 692.

559. P. AREEDA, supra note 96 , at 91508 , at 408 .

560. 468 U.S. 85 (1984).

561. Id. at 99 .

562. Id.

563. Id. at 100 .

564. Id. at 101 .

565. Id. at 102

566. Id. at 104 .

567. Id. at 104 n.28.

568. Id

569. Id.
} 
competitive justification" be shown for the restraint, "even in the absence of a detailed market analysis" that would establish the presence of market power. 570 Where there is a potentially "naked" restraint-that is, one with "no purpose except stifling of competition"571-which "constitutes a restraint upon the operation of the free market," 572 the Court will require that the defendant, as an "affirmative defense," bear the "heavy burden" of persuasion in demonstrating that there are procompetitive justifications that outweigh the "apparent deviation from the operations of a free market." 573

Thus, NCAA establishes the principle that, under a rule of reason analysis, certain restraints will have such "significant potential for anticompetitive effects" 574 as to warrant placing the burden of establishing an overriding procompetitive justification on the defendant. ${ }^{575}$ Moreover, in such circumstances, a plaintiff need not present evidence concerning market power; the defendant's duty to establish a procompetitive justification for such restraints exists once plaintiff shows that the restraint in question has the necessary "hallmarks of anticompetitive behavior" 576 that are "likely enough to disrupt the proper functioning of the . . . market." 577

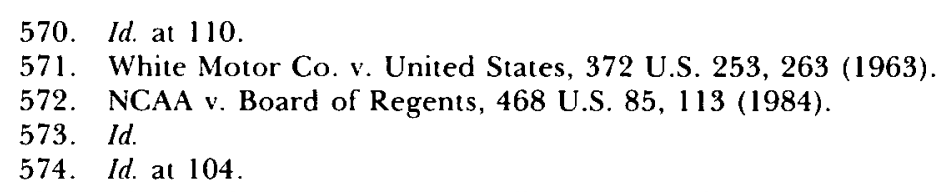

575. Id. at 113. Accord FTC v. Indiana Fed'n of Dentists, 476 U.S. 447, 459-62 (1986). It is important to note, in this regard, that the affirmative defense asserted must be established by demonstrating its procompetitive characteristics-not by claiming some other "worthy purpose" unrelated to the promotion of competition. See id. at 462-64 (noncompetitive quality-of-care considerations not relevant to rule of reason analysis).

576. NCAA v. Board of Regents, 468 U.S. at 113.

577. Indiana Fed' $n$ of Dentists, 476 U.S. at $461-62$. There is a certain parallel between the antitrust approach developed in NCAA and Indiana Federation of Dentists, and the constitutional doctrine of equal protection involving suspect classifications. Where a system of categorization such as race is utilized, the Supreme Court has labeled such classifications suspect, and the presumption of validity is eliminated. The burden of justification shifts to the party adopting the classification to show that its use is necessary-i.e., no viable alternatives exist-to promote a compelling (and not just a legitimate) governmental interest. See, e.g., City of Cleburne v. Cleburne Living Center, 473 U.S. 432 (1985). (The same analysis applies to the burdening of fundamental interests. See Dunn v. Blumstein, 405 U.S. 330 (1972)). Suspect classifications are not per se unconstitutional under equal protection, since the Court will listen to purported justifications. Thus, despite the racial basis of a classification setting aside a certain proportion of government contracting jobs for minority-owned firms, such set asides have not been deemed per se unconstitutional. See Fullilove v. Klutznick, 448 U.S. 448 (1980). Yet, they can only be upheld if the government can show that they are designed to promote compelling governmental interests and if it can demonstrate that they are narrowly tailored to achieve those goals-for example, that other reasonable alternatives are not available. See Richmond v. J. A. Croson Co., 109 S. Ct. 706 (1989).

While the Supreme Court has moved away from the per se approach in certain group boycott contexts, it has recognized that certain restraints are so likely to be anticompetitive in character that it has reduced the elements plaintiffs must prove and has required, under NCAA and Indiana Federation of Dentists, that those seeking to justify the restraint demonstrate its procompetitive features. These types of restraints are, therefore, not per se illegal under the antitrust laws because, in theory, justifications can be asserted. Yet, they have been assigned a status analytically akin to a "suspect classification" in that they must be shown by their proponents to be procompetitive in effect. Plaintiffs need not prove their anticompetitive impact. Rather, a "concerted and effective effort to withhold (or make more costly) information desired by consumers for the purpose of determining whether a particular purchase is cost-justified is likely enough to disrupt the proper 
ii. Application of the rebuttable presumption to specific circumstances. It is now appropriate to revisit the physician cartel behavior condemned by Kissam, Webber, Bigus and Holzgraefe. ${ }^{578}$ Physician cartel behavior, according to Kissam and his co-authors, occurs " $[\mathrm{w}]$ hen hospitals and medical staffs agree or act consistently to deny privileges to other physicians because of their status as competitors ...."579 They persuasively argue that physician cartel behavior constitutes a naked restraint with the potential for "clear harms to competition and the absence of any procompetitive justification for these kinds of decisions." 580 On that basis, they recommended that the following types of restrictions be considered per se illegal:581 (1) Exclusion of physicians because of their association with direct competitors of the hospital's fee-for-service medical staff (for example, HMO's, ambulatory surgical centers); (2) limitation of staff privileges to those who are members of or who agree to join existing partnerships of physicians who currently hold medical staff privileges; ${ }^{582}$ (3) restrictions on staff privileges aimed at punishing or eliminating competitors (for example, barring categories of practitioners such as osteopaths or family practitioners). Based on the Supreme Court's decision in Northwest Wholesale Stationers, we rejected the per se approach to physician cartel decisions in the absence of an affirmative showing of market power. ${ }^{583}$ The foregoing analysis of $N C A A^{584}$ and Indiana Federation of Dentists, ${ }^{585}$ however, strongly suggests that these physician cartel decisions be subject to the rule requiring defendants to establish an overriding procompetitive justification, even in the absence of a showing by a plaintiff of a defendant hospital's market power.

As Kissam and his co-authors demonstrate, these types of "physician cartel" restraints pose a "significant potential for anticompetitive effects." 586 The historical institutional relationships within the hospital dictate a precautionary prophylactic approach to this type of restraint. ${ }^{587}$ The economic and sociological research ${ }^{588}$ on hospitals also suggests that these physician cartel activities have the necessary "hallmarks of anticompetitive

\footnotetext{
functioning of the price-setting mechanism of the market that it may be condemned even absent proof that it resulted in higher prices ... than would occur in its absence." Indiana Fed 'n of Dentists, 476 U.S. at $461-62$.

Thus, the rule of reason approach adopted in NCAA and Indiana Federation of Dentists bears a certain intellectual kinship with the equal protection doctrine of suspect classification, requiring the defenders to justify the conduct and requiring a close relationship between the means used and the goals asserted. NCAA, 468 U.S. at 118-119. Cf. Hughes v. Oklahoma, 441 U.S. 322 (1979) (state laws that discriminate against interstate commerce receive the strictest scrutiny).
}

578. See supra Part IV.B.4.a.

579. Kissam, Webber, Bigus \& Holzgraefe, supra note 69 , at 651 .

580. Id. See supra notes $479-83$ and accompanying text.

581. See supra Part IV.B.4.a.

582. See suprn note 480.

583. See supra text accompanying notes 506-07

584. NCAA v. Board of Regents, 468 U.S. 85 (1984).

585. FTC v. Indiana Fed'n of Dentists, 476 U.S. 447 (1986).

586. NCAA v. Board of Regents, 468 U.S. 85, 104 (1984).

587. See supra p. 15 (Part II.C.1).

588. See supra p.15 (Parts II.C.2., 3). 
behavior" 589 that are "likely enough to disrupt the proper functioning of the . . . market" 590 so as to thrust a burden of justification on the defendant hospital.

The critical difference, in this regard, between a per se rule of invalidity and a rebuttable presumption of invalidity under the rule of reason is the opportunity for procompetitive justification provided to a defendant by the rule of reason. ${ }^{591}$ Thus, a defendant hospital would be able to show that a particular restriction had a procompetitive purpose and effect-for example, promoting a marketing strategy, limiting excessive costs for purposes of enhancing profitability, or reducing exposure to medical malpractice liability. In attempting to satisfy its burden of establishing a successful procompetitive defense, a defendant hospital would have to show that its procompetitive justification is not just theoretical but factually demonstrable. It would have to show that its restraint is "substantially related to the ... pro-competitive purposes" it asserts. Otherwise, "an inference of anti-competitive animus might be appropriate." 592 In short, a defendant hospital seeking to justify a physician cartel decision on procompetitive grounds should be required to establish that the restraint is not a pretext for anticompetitive conduct ${ }^{593}$ but rather is designed in fact and implemented in such a way as to achieve procompetitive institutional objectives and is "tailored to serve such [a procompetitive] interest." 594

iii. The implications of the Health Care Quality Improvement Act. An objection might be raised that this rebuttable presumption approach could have the effect of encouraging increased protracted litigation-that it reverses the presumption of validity contained in HCQIA for peer-review conduct. We do not believe that that concern is significant; to the extent, however, that increased litigation does occur, we believe that the risks to competition are substantial enough to warrant intensified judicial inquiry.

In most hospital staff privilege cases, the hospital's first line of defense will be the immunity provided for by HCQIA.$^{595}$ A first-glance review of the limited HCQIA immunity provisions would suggest that participants in the peer-review process-that is, in a "professional review action"596_are

589. NCAA v. Board of Regents, 468 U.S. 85, 113 (1984).

590. FTC v. Indiana Fed'n of Dentists, 476 U.S. 447, 461-62 (1986).

591. See supra note 577.

592. Northwest Wholesale Stationers, Inc. v. Pacific Stationery \& Printing Co., 472 U.S. 284, 296 n.7 (1985)

593. Id.

594. NCAA v. Board of Regents, 468 U.S. 85, 119 (1984). The nature and the rationale for the hospitals' decisions will undoubtedly be the subject of scrutiny if hospitals seek the immunity shield afforded by the HCQIA. See supra notes 495-503 and accompanying text. The decisions of hospitals will also be viewed in the context of the marketplace and evaluated in terms of objectively plausible procompetitve rationales for the conduct in question. See Matsushita Elec. Indus. Co. v. Zenith Radio Corp., 475 U.S. 574, 587, 596-97 (1986).

595. 42 U.S.C. $\$ 11111$ (a) (Supp. 1988).

596. HCQIA provides immunity from damages for a "professional review action." Id. The term is defined at 42 U.S.C. $\$ 11151$ (a) (Supp. 1988). See supra notes 495-503 and accompanying text. 
presumed to have acted in good faith and in furtherance of health care quality, thereby qualifying for HCQIA immunity. ${ }^{597}$

Specifically, HCQIA provides for immunity for liability from damages for a "professional review action" if, among other requirements, the review action is carried out "in the reasonable belief that the action was in the furtherance of quality health care" 598 and "in the reasonable belief that the action was warranted by the facts ...." 599 After setting out the requirements that trigger immunity, HCQIA further imposes a duty on a complainant to prove that the peer-review activity did not satisfy those statutorily enumerated requirements for immunity: "A professional review action shall be presumed to have met the .. . standards necessary" for immunity "unless the presumption is rebutted by a preponderance of the evidence." 600 That presumption suggests that a plaintiff will have to shoulder the obligation of proving bad faith in the peer-review process in order to offset the HCQIA immunity provisions.

Upon further analysis, however, there is less here than meets the eye. HCQIA establishes a presumption that a "professional review action" is presumed to have been carried out in good faith. ${ }^{601}$ Yet that protection is only available to a carefully defined "professional review action." To qualify for the presumption of good faith (and therefore HCQIA immunity), a defendant must establish the existence of a "professional review action," a term defined by HCQIA to require a peer-review judgment "based on the competence or professional conduct of an individual physician." 602 Thus, to fall within the scope of HCQIA immunity, a defendant must show that the peer-review conduct was based on the physician's competence or professional

597. See, e.g. Colantonio, The Health Care Quality Improvement Act of 1986 and Its Impact on Hospital Law, 91 W. VA. L. Rev. 91, 94 (1988). Colantonio argues that, unless rebutted, the statutory presumption means that "all review actions have met" the requirements for HCQIA immunity. He asserts that the challenging "physician carries the burden of proof to establish that a particular review action failed to meet [the statutory] standards." Id. For the reasons elaborated in text, infra notes 601-14 and accompanying text, the practical operation of HCQIA will place the burden on the hospital and physician defendants to establish that the peer-review decision was based on the physician's competence. See 42 U.S.C. $\$ 11151$ (9) (Supp. 1988). That will largely vitiate the seeming presumption of immunity.

598. 42 U.S.C. $\$ 11112(\mathrm{a})(1)$ (Supp. 1988). The "reasonable belief" standard is designed to embrace both a subjective and an objective good faith test. The objection to a straight good faith test is its subjectivity. The reasonable belief language imposes an objective reasonableness requirement and allows for use of expert testimony on the reasonableness of a medically-based judgment. See H.R. ReP. No. 99-903, 99th Cong., 2d Sess. 10, reprinted in 1986 U.S. Code Cong. \& Admin. News 6384, at 6392-93. "The 'reasonable belief' standard should protect a physician under review by making it difficult for an objectively vindictive peer review action to qualify for the protection of the Act." See Note, supra note 7, at 1123 . The Virginia Note duly observes the existence of the statutory presumption that the "reasonable belief" standard is satisfied, but erroneously quotes an earlier version of the statute, which had established a "clear and convincing evidence" standard for rebutting the presumption. See id. at n.48. As ultimately enacted, the standard for rebutting the presumption is "preponderance of the evidence." 42 U.S.C. $\$ 11112(a)(4)$ (Supp. 1988). For our view that this presumption, in any event, is of little practical importance, see supra note 597; infra notes $601-14$ and accompanying text.

599. 42 U.S.C. $\$ 11112$ (a)(4) (Supp. 1988).

600. Id. $\$ 11112(\mathrm{a})$.

601. Id. $\$ \$ 11111(\mathrm{a})(1), 11112(\mathrm{a})$.

602. Id. $\$ 11151(9)$. 
conduct. Presumably, on that issue, the defendant retains the burden of persuasion since the immunity appears to be in the nature of an affirmative defense. ${ }^{603}$

Moreover, HCQIA expressly puts outside the scope of its immunity provisions specified conduct that raises concerns to competition, including the physician cartel conduct condemned by Kissam and his co-authors. ${ }^{604}$ Clearly, Congress believed that such behavior should not qualify for antitrust immunity. Thus, within the context of HCQIA proceedings, there will necessarily be significant litigation to determine whether the defendant can establish that its conduct falls within the ambit of HCQIA immunity-that is, that it is "based on the competence or professional conduct of an individual physician" 605 and not "primarily based"606 on the physician's professional memberships, ${ }^{607}$ his competitive conduct (such as fees or advertising), ${ }^{608}$ his participation in prepaid group health plans or in salaried employment, ${ }^{609}$ or his association with, or supervision of, or delegation to "a particular class of health care practitioner or professional." 610 To give even greater emphasis to this point, HCQIA expressly withdraws immunity from any other peer-review activity "that does not relate to the competence or professional conduct of a physician."'611 In sum, to qualify for the presumption of immunity under HCQIA, ${ }^{612}$ a defendant must establish the existence of a "professional review action." 613 That, in turn, requires a showing that the peer-review conduct at

603. Cf. NCAA v. Board of Regents, 468 U.S. 85, 113 (1984) (burden of establishing an affirmative defense is on party asserting that defense). It should be clear, therefore, that motivation will be an inevitable component of a staff privileges lawsuit where immunity under HCQIA is at issue. See infra notes 604-23.

604. 42 U.S.C. $\$ 11151(9)($ A)-(E) (Supp. 1988).

605. Id. at $\$ 11151(9)$.

606. Id. The HCQIA section that defines the term "professional review action" is structured so as to carve out and exclude specific conduct from coverage under the term "professional review action." The limiting provision reads as follows: "[A]n action is not considered to be based on the competence or professional conduct of a physician if the action is primarily based on ...." The provision then enumerates the non-immune conduct described infra in text accompanying notes 607 . 12. The "primarily based" terminology reflects an intellectual debt to the "dominant anticompetitive purpose" approach advocated by Kissam, Webber, Bigus \& Holzgraefe, supra note 69, at 659-62. Quite clearly, investigation into whether a decision is "primarily based" on physician competence, which is HCQIA immune, or on some other factor, which is not HCQIA immune, will necessitate judicial inquiry into motivation. Thus, the enactment of HCQIA, whose immunity provisions surely will be invoked by hospitals and their physician staff members in staff privileges antitrust cases, virtually assures the kind of purpose-based analysis Professor Havighurst has sought to discourage. See Havighurst, supra note 395, at 1127, 1129, 1134-36; supra note 446.

607. 42 U.S.C. $\S 11151(9)$ (A) (Supp. 1988).

608. Id. $\S 11151(9)(\mathrm{B})$.

609. Id. $\$ 11151(9)(\mathrm{C})$.

610. Id. $\$ 11151(9)(\mathrm{D})$.

611. Id. $\$ 11151(9)(\mathrm{E})$. The inclusion of section $11151(9)(\mathrm{E})$ is striking because it reemphasizes the standard for HCQIA immunity-namely, that decisions be based on physician competence. By enumerating in sections 11151 (A)-(D) the specific conduct that would not be deemed based on physician competence, Congress did not want to leave open the possibility that the enumerated list would be construed as exhaustive.

612. Id. §11112(a).

613. Id. $\S 11111(\mathrm{a})(1)$. 
issue was based on matters related "to the competence or professional conduct of a physician." 614

This parsing of HCQIA reveals that a staff privileges lawsuit will very quickly become enmeshed in questions related to the basis of the defendant's peer-review conduct. Despite the ostensible statutory presumption that peer review has been carried out in the "reasonable belief" that it furthered "quality health care," 615 the defendant must establish that the peer review qualifies as a "professional review action" 616 and is "based on the competence or professional conduct of an individual physician." 617 If the defendant cannot establish the appropriate grounds for HCQIA immunity, then the issue is litigated under traditional antitrust principles. ${ }^{618}$ Under our approach, that defendant, on the merits of the antitrust claim and in the context of physician cartel behavior, would be required to demonstrate the procompetitive rationale and effect of the challenged restrictive conduct. It would be required to address such issues as motivation, consistency with implementation of an overall competitive strategy, and external theoretical support for the competitive rationale. Since no showing by plaintiff of a defendant's market power would be necessary, ${ }^{619}$ a less complex proceeding would be contemplated under our approach. Our conclusion, therefore, is that substantial additional litigation is not likely; if it arises, it is warranted by the risks to competition from the kinds of horizontal restraints that once were deemed sufficiently threatening to competition as to warrant a broadly applicable rule of per se invalidity. ${ }^{620}$ When that historical skepticism towards horizontal restraints is linked with the special characteristics of the hospital industry, ${ }^{621}$ the historical experience with physician cartel activities, ${ }^{622}$ and the provisions of HCQIA, ${ }^{623}$ it appears appropriate to impose a rebuttable presumption against the validity of physician cartel restraints. Hospitals will be afforded an opportunity to justify these restraints, but they will bear the burden of persuasion that procompetitive elements outweigh the substantial risks to competition.

Through this approach, antitrust doctrine can serve as a tool for discouraging anticompetitive conduct that cannot withstand analytical scrutiny. At the same time, it will provide a safe harbor, in addition to HCQIA, for truly competitive conduct, even if not immunized by HCQIA's terms.

614. Id. $\S 11151(9)$.

615. Id. $\$ 11112(\mathrm{a})(1)$.

616. Id. $\S 11111(\mathrm{a})(1)$.

617. Id. $\$ 11151(9)$.

618. Id. §11115(a).

619. See FTC v. Indiana Fed'n of Dentists, 476 U.S. 447, 460-61 (1986); NCAA v. Board of Regents, 468 U.S. 85, 109-10 (1984).

620. See supra note 577 (analogizing the approach in NCAA and Indiana Fed'n of Dentists and recommended here to the "suspect classification" doctrine of equal protection.)

621. See supra p.14 (Part II.C).

622. See Kissam, Webber, Bigus \& Holzgraefe, supra note 69, at 651-55.

623. 42 U.S.C. $\S \S 11111$ (a)(1), $11112(\mathrm{a}) .11151$ (9) (Supp. 1988). 
b. Application of the rule of reason: the general case. In the absence of physician cartel conduct, the rule of reason analysis should proceed along traditional lines. A complainant would bear the burden of demonstrating that the challenged activity is, on balance, detrimental to competition. ${ }^{624}$ To the extent that the conduct is protected as a "professional review action" under HCQIA, ${ }^{625}$ no liability for damages exists. ${ }^{626}$ Yet, even where HCQIA immunity exists, a plaintiff can proceed on a liability theory for relief other than for damages, ${ }^{627}$ provided that he can survive a motion for summary judgment. Under recent caselaw developments in the area of summary judgment, however, a plaintiff must develop substantial evidence of an antitrust violation in order to get to trial.628 Moreover, under the rule of reason the courts have been willing to apply a "quick look" approach as a means of decreasing the need for an extensive trial of complex factual issues. ${ }^{629}$ The quick look approach would be appropriate in the bulk of cases that are covered by the limited immunity provided by HCQIA. In those cases, summary judgment on the issue of liability would likely be appropriate unless a plaintiff can develop evidence that would point to a realistic threat to competition. ${ }^{630}$

If a rule of reason case proceeds beyond the summary judgment stage, a court must evaluate a multiplicity of factors. ${ }^{631}$ In general, the closer a defendant's restrictive and collective behavior comes to the theoretical case for collusive self-interest, the more likely it should be deemed anticompetitive in character. The closer the relationship-that is, the better the fit-between the restraint and the legitimate, procompetitive rationale, the stronger the case should be for upholding the restraint under the rule of reason. ${ }^{632}$ The following factors will be particularly important as areas of focused inquiry.

i. Market conditions. The ability of a group, through concerted action, to exert anticompetitive influence depends on market conditions. The term

624. See National Soc'y of Professional Eng'rs v. United States, 435 U.S. 679, 691 (1978).

625. 42 U.S.C. $\$ \S 11111$ (a)(1), 11151 (9) (Supp. 1988).

626. HCQIA immunity only extends to liability for damages. Id. $\$ 11111$ (a)(1). It does not apply to civil rights actions, including claims arising under 42 U.S.C. $\$ 1983$, and it does not bar enforcement actions by the United States or by the attorney general of any state. 42 U.S.C. $\$ 11111(\mathrm{a})(1)$.

627. 42 U.S.C. $\$ 11111$ (a)(1) (Supp. 1988).

628. See, e.g., Collins v. Associated Pathologists, Ltd., 844 F.2d 473 (7th Cir. 1988); Cooper v. Forsyth County Hosp. Authority, Inc., 789 F.2d 278 (4th Cir. 1986).

629. See, e.g., FTC v. Indiana Fed'n of Dentists, 476 U.S. 447, 459 (1986) ("no elaborate industry analysis is required [under the rule of reason] to demonstrate the anticompetitive character of ... an agreement [among dentists to withhold x-rays from insurance companies]") (quoting National Soc'y of Professional Engineers v. United States, 435 U.S. 679, 692 (1978)).

630. See, e.g., Friedman v. Delaware County Memorial Hosp., 672 F. Supp. 171, 187-90 (E.D. Pa. 1987), aff'd per curiam, 849 F.2d 600, 603 (3d Cir. 1988).

631. See, e.g., Kreuzer v. American Academy of Periodontology, 735 F.2d 1479 (D.C. Cir. 1984).

632. See id. at 1494 ("[W]hen the economic self-interest of the boycotting group and its proffered justifications merge the rule of reason will seldom be satisfied. When, however, the justification for the boycott is closely related to a lawful purpose the rule of reason will generally be satisfied."). See also Northwest Wholesale Stationers, Inc. v. Pacific Stationery \& Printing Co., 472 U.S. 284, 297 n.9 (1985). 
"market power" is used to denote a point along a continuum at which the threat to competition becomes sufficiently palpable so as to warrant the conclusion that a restraint adversely affects competitive conditions. Before that point on the continuum is reached-and there often is not a consensus among experts about where that point lies-there is increasing risk of adverse effects on competition. ${ }^{633}$ Thus, analysis of a market involves a sliding scale of conditions that have varying effects on competitive circumstances. The inquiry underlying the determination of market power requires consideration of where, along the continuum, the adverse effect on competition becomes sufficiently palpable to warrant application of the label. That does not mean that degrees of market concentration short of market power are analytically irrelevant. To the contrary, evidence of high levels of market concentration is germane because of reasonable inferences that can be drawn about risks to competition-risks that might be overridden by operating efficiencies, marketing advantages, or other offsetting procompetitive factors.

In a rule of reason analysis, therefore, consideration of market conditions is important since market concentration is a factor suggesting the potential for anticompetitive consequences from a restraint. Since rule of reason analysis necessitates an evaluation and a balancing of procompetitive and anticompetitive factors that stem from a restraint, it is important to understand the potential harm to competition from market concentration. ${ }^{634}$ To the extent that substitutes or alternatives are readily available at little or no disadvantage to the consumer or competitor, the risk to competition from a restraint is low. As substitutes or alternatives become less accessible, less attractive, or otherwise more costly, the potential adverse impact on competition is higher and requires justification by establishing the existence of more clear-cut procompetitive offsetting virtues.

ii. Motivation. In a rule of reason analysis, a plaintiff has an opportunity to show anticompetitive motivation. ${ }^{635}$ First, under HCQIA, the presumption of good faith ${ }^{636}$ of a "professional review action" is subject to rebuttal by a "preponderance of the evidence." 637 The legislative history of

633. The Supreme Court has said that "the purpose of the inquir[y] into market . . power is to determine whether an arrangement has the potential for genuine adverse effects on competition." Indiana Fed'n of Dentists, 476 U.S. at 460-61. Market power has been described as a "surrogate for detrimental effects" on competition. 7 P. AREEDA, supra note 96, at $\uparrow 1511$, at 429, quoted approvingly in FTC v. Indiana Fed'n of Dentists, 476 U.S. 447, 460-61 (1986).

Beyond the market power threshold, increasing levels of concentration may also permit further increased anticompetitive effects. That issue, however, is not addressed here.

634. See Indiana Fed'n of Dentists, 476 U.S. at 460-61.

635. See, e.g., Northwest Wholesale Stationers, 472 U.S. at 296 n.7; Oltz v. St. Peter's Community Hosp. 861 F.2d 1440 (9th Cir. 1988).

636. The term "good faith" is continually used in place of the "reasonable belief" standard in the statute. 42 U.S.C. $\$ \$ 11112(\mathrm{a})(1)$, (4) (Supp. 1988). The statutory language makes clear that the immunity attaches only where the review activity is carried out in good faith, in both a subjective as well as in an objective sense. See supra note 598. See also Note, supra note 7, at 1123.

637. 42 U.S.C. $\$ 11112(\mathrm{a})(4)$ (Supp. 1988). An earlier version of the statute required rebuttal by "clear and convincing evidence." See 144 Cong. Rec. H11590-91 (daily ed. Oct. 17, 1986). 
HCQIA makes it clear that no immunity was intended for bad faith ${ }^{638}$ peerreview activities. ${ }^{639}$

Second, evidence of bad faith may "raise a probability of anticompetitive effect." 640 As the Supreme Court explained in Northwest Wholesale Stationers, a plaintiff can avail himself of the opportunity, under the rule of reason, to show that a restraint is not in fact justified by a procompetitive rationale but rather serves as a "pretext" for anticompetitive conduct. ${ }^{641}$ The Northwest Wholesale Stationers Court acknowledged that "[s]uch [an anticompetitive] motive might be more troubling." 642 A restraint that in fact is "not substantially related to ... procompetitive purposes" 643 that are offered in justification may "imply anticompetitive animus and thereby raise a probability of anticompetitive effect." 644

In Goss v. Memorial Hospital System, ${ }^{645}$ the physician-complainant alleged that he was expelled from the hospital staff so that he would be driven out of the profession and thus "eliminate[d] . . a as a competitor." ${ }^{446}$ The result would be "to permit some of the defendants to take over [plaintiff's] medical practice." 647 While rejecting plaintiff's claim that a per se rule of invalidity should apply, the Fifth Circuit noted the propriety of taking such considerations into account in the context of a rule of reason analysis. ${ }^{648}$

Thus, an important factor for consideration in a rule of reason analysis is the intent underlying a potentially anticompetitive restraint. Behavior that seemingly is consistent with an anticompetitive animus will be viewed more harshly if a plaintiff can show that there is little likelihood that the conduct was entered into for procompetitive reasons. ${ }^{649}$

iii. The nature of the challenged conduct. Where a staff privileges decision can be characterized as vertical rather than horizontal in character, there is less reason to be concerned about anticompetitive consequences. ${ }^{650}$ Evidence that tends to support the vertical characterization should be considered as affirmative support in justification of a restraint.

Evidence in support of the vertical nature of a staff privileges decision must be objective as well as subjective in character. It should go well beyond the formalities-hospital board minutes, internal memoranda, and similar documents. Evidence of vertical decisionmaking should show a pattern of

638. See supra notes 598,636 .

639. See 144 Cong. Rec. H11590 (daily ed. Oct. 17, 1986). See also supra note 606.

640. Northwest Wholesale Stationers, Inc. v. Pacific Stationery \& Printing Co., 472 U.S. 284, 296

(1985).

641. Id. at 296 n.7.

642. Id.

643. Id.

644. Id. at 296.

645. 789 F.2d 353 (5th Cir. 1986).

646. Id. at 354 .

647. Id. at 355 n.3.

648. Id.

649. See Aspen Skiing Co. v. Aspen Highlands Skiing Corp., 472 U.S. 585, 600-11 (1985).

650. See supra text accompanying notes 85-104; see also supra p.56 (Part IV.B.2). 
procompetitive institutional policy of which the specific decision at issue is a clear, logical part. Such evidence should also be subject to scrutiny in terms of the consistency of the conduct in question with external theories of rational competitive behavior. Thus, to be viewed as vertical in character, hospital staffing decisions should be justified in fact as well as in theory by reference to other compatible procompetitive hospital policies. ${ }^{651}$

\section{V}

\section{CONCLUSION}

At the very outset of this article, we discussed the cultural dissonance that exists for many in the application of antitrust principles to the health care industry. ${ }^{652}$ As our analysis demonstrates, antitrust principles are fully applicable to the hospital peer-review context, ${ }^{653}$ although, as in any new environment, antitrust principles must be appropriately fine-tuned and adapted. ${ }^{654}$

651. One factor that often can be probative is the relationship between the hospital and its medical staff concerning a particular decision. Consider White v. Rockingham Radiologists, Ltd., 820 F.2d 98 (4th Cir. 1987), in which the hospital gave an exclusive contract to a group of radiologists. The medical staff voted to allow $\mathrm{Dr}$. White, a neurologist, to give official interpretations of CT head scans, but the hospital board gave exclusive authority to provide official interpretations to the radiologists "on grounds that one entity should be responsible for the entire CT operation." Id. at 101. The court found that the hospital board acted unilaterally, reaching its own decision that "assigning full responsiblity for scans to the radiologists, rather than fragmenting accountability, would best serve the interests of patients and promote efficient use of the scanner." Id. at 103.

See also Smith v. Northern Mich. Hosps., Inc., 703 F.2d 942, 952-54 (6th Cir. 1983) (holding valid an exclusive contract with a group of physicians to staff an emergency room). The court found that the hospital "chose to staff its ... emergency room with full-time specialists in emergency care for undisputedly legitimate financial and medical reasons." Id. at 953. No evidence refuted the hospital's view that "full-time specialists trained as emergency room physicians provide medical services superior to those of generalists who rotate on a part-time basis while maintaining full private practices." Id. The court viewed the hospital's behavior as vertical not horizontal in character. The hospital acted to promote its interest in quality and not to force plaintiff physicians out of any market. Id.

Cf. Jefferson Parish Hosp. Dist. No. 2 v. Hyde, 466 U.S. 2 (1984), in which Dr. Hyde, a board certified anesthesiologist who applied for staff privileges, was affirmatively recommended by the medical staff, but was denied privileges by the hospital board because of an exclusive contract between the hospital and a group of anesthesiologists. The majority treated the issue as involving a tying arrangement-hospital services were deemed a product distinct from anesthesiological services. The dissent analyzed the case as an exclusive-dealing contracts case. For our purposes, Hyde is an example of a vertical decision by the hospital, a case in which the hospital board rejected the recommendation of its medical staff. For this reason, the Supreme Court's analysis steered away from boycott or concerted-refusal-to-deal issues and concentrated on tying or exclusive-contracts antitrust theories.

652. See supra p.8 (Part I).

653. See, e.g., Patrick v. Burget, 108 S. Ct. 1658 (1988); Bolt v. Halifax Hosp. Medical Center, 851 F.2d 1273 (11 th Cir.), vacated and petition for reh'g en banc granted, 861 F.2d 1233 (1lth Cir. 1988), reinstated in part and vacated in part en banc, 874 F.2d 755 (1 lth Cir. 1989); Goss v. Memorial Hosp. Sys., 789 F.2d 353 (5th Cir. 1986); Miller v. Indiana Hosp., 843 F.2d 139 (3d Cir. 1988); Nanavati v. Burdette Tomlin Memorial Hosp., 857 F.2d 96 (3d Cir. 1988); Smith v. Northern Mich. Hosps., Inc., 703 F.2d. 942 (6th Cir. 1983); White v. Rockingham Radiologists, Lid., 820 F.2d 98 (4th Cir. 1987); Weiss v. York Hosp., 745 F.2d 786 (3d Cir. 1984).

654. See generally FTC v. Indiana Fed'n of Dentists, 476 U.S. 447 (1986); NCAA v. Board of Regents, 468 U.S. 85 (1984); National Gerimedical Hosp. \& Gerontology Center v. Blue Cross, 452 U.S. 378 (1981); Broadast Music, Inc. v. Columbia Broadcasting Sys., Inc., 441 U.S. 1 (1979). 
Historically, hospitals have not typically functioned as traditional economic entities. ${ }^{655}$ Physicians have exerted great influence on hospital decisionmaking and, with the growing importance of hospitals to medical practice, physicians holding staff privileges have had opportunities to use their power for anticompetitive purposes-to act collectively as members of the medical staff to advance their own economic interests at the expense of actual or potential competitors. ${ }^{656}$ It has even been argued, in this regard, that the nonprofit organizational form is inappropriate for the hospital industry. ${ }^{657}$

The antitrust laws are premised on the assumption that competition constitutes the best means for allocating resources. ${ }^{658}$ Partly because of the elimination of barriers to the application of the antitrust laws to the medical care field, ${ }^{659}$ the health care industry has become much more characterized by competition over the last decade. ${ }^{660}$ Perhaps the most telling illustration of the assumption that antitrust should apply to the health care industry-that competitive values should be protected in that economic sector-is the debate surrounding the enactment of HCQIA in $1986 . .^{661}$

When concern emerged about the risk to peer review from antitrust, Congress followed the pattern in other industries ${ }^{662}$ by carefully carving out a limited immunity from antitrust for peer-review activities. Yet, the legislation that eventuated was a balanced compromise that recognized the desirability of preserving competition in the hospital industry and the risks of immunizing anticompetitive conduct under the guise of quality assurance. ${ }^{663}$

An understanding of the historical, economic, sociological, and organizational perspectives of the hospital ${ }^{664}$ is needed for developing a nuanced doctrinal approach to antitrust in the crucible of hospital peer review. Such a multi-disciplinary perspective leads us to conclude that the threshold requirement of a Sherman Act section 1 violation-concerted action by more than one party 665 -is satisfied in the context of hospital staff decisions. The capacity for both horizontal and vertical concerted activity exists. ${ }^{666}$

655. See supra p.10 (Part II).

656. See, e.g., Weiss v. York Hosp., 745 F.2d 786 (3d Cir. 1984).

657. See Clark, supra note 64.

658. See, e.g., National Soc'y of Professional Eng'rs v. United States, 435 U.S. 679 (1978).

659. See FTC v. Indiana Fed'n of Dentists, 476 U.S. 447 (1986); Jefferson Parish Hosp. Dist. No. 2 v. Hyde, 466 U.S. 2 (1984); Arizona v. Maricopa County Medical Soc'y, 457 U.S. 332 (1982); National Gerimedical Hosp. \& Gerontology Center v. Blue Cross, 452 U.S. 378 (1981); National Soc'y of Professional Eng'rs v. United States, 435 U.S. 679 (1978); see also Goldfarb v. Virginia State Bar, 421 U.S. 773 (1975) (holding that bar associations setting minimum fees are not exempt from Sherman Act).

660. See Greenberg, Introduction, 13 J. Health Pol., Pol'y \& L. 223 (1988).

661. See supra text accompanying notes 500-503.

662. See National Soc y of Professional Eng'rs, 435 U.S. at 690 n.14.

663. See supra text accompanying notes 495-505; see also p.82 (Part IV.B.5.a.iii).

664. See supra p. 10 (Part II).

665. See Copperweld Corp. v. Independence Tube Corp., 467 U.S. 752 (1984).

666. See supra p.37 (Part IV.A). 
The goal of antitrust policy should be the encouragement of hospital decisionmaking that more nearly approaches the mode of decisionmaking of more traditional economic entities such as firms. In this regard, we are in agreement with the objectives espoused by Professor Havighurst, who urges that the hand of hospitals be freed to allow them to act on behalf of consumers. ${ }^{667}$ His analysis, which advocates a more restrained role for antitrust than we do, is premised "on the assumption that hospitals dispensing admitting privileges will generally act in accordance with consumer interests to the extent that the external environment permits." 668 His approach, therefore, seeks to foster a more permissive environment from the perspective of antitrust doctrine.

Our view is that historically entrenched attitudes, professional prerogatives, economic dependence, institutional structural rigidities, ${ }^{669}$ and legal doctrines ${ }^{670}$ have created headwinds against the kind of hospital role Professor Havighurst envisions. In this regard, we believe that the antitrust laws have a positive role to play in compelling hospitals to act more like competitive economic entities. It is insufficient, in our view, for antitrust doctrine to disengage from this area when risks to competition continue to persist. Antitrust doctrine surely should not hinder the development of more autonomous modes of behavior by hospital administrators. On that we concur wholeheartedly with Professor Havighurst. But we are also a bit more ambitious. Given the recent emergence of a procompetitive weltanschauung in the health care industry, we believe that a more pro-active role for antitrust is possible and appropriate.

We, therefore, have proposed a doctrinal approach that would require, in the most risky areas-physician cartel behavior-, that hospitals shoulder the burden of demonstrating the procompetitive character of decisions that, based on history and the insights of social science research, one can reasonably label prima facie anticompetitive. ${ }^{671}$

We do not urge a promiscuous heavy hand of antitrust on hospital peerreview decisions. Rather, in the particular areas in which we have reason to worry about the effects on competition of hospital decisionmaking, we want the hospital to be under an obligation to demonstrate (and not merely assert) its autonomy and its procompetitive rationale. That requirement may put hospitals to their proof in some circumstances, but they are on notice of their need to act in these areas in demonstrably procompetitive ways. ${ }^{672}$

667. See Havighurst, supra note 395 , at $1157-62$.

668. Id. at 1158 .

669. For a discussion of the accrediting standards of the JCAH (now JCAHO), see Jost, supra note 249; for a discussion of the antitrust implications of this system of accreditation, see Havighurst \& King, Private Credentialing of Health Care Personnel: An Antitrust Perspective, 9 AM. J. L. \& MED. 263 (1983).

670. The legal barriers to effective and autonomous hospital decisionmaking are reviewed in Hall, supra note 41 .

671. See supra p.78 (Part IV.B.5.a).

672. These issues are likely to be litigated in any event because of the provisions of HCQIA. See supra note 606 . 
We have also recommended a way-presaged by HCQIA-in which hospitals can minimize their exposure. HCQIA calls for peer review by persons "not in direct economic competition with the physician involved." 673 Congress recognized that fulfilling that requirement might necessitate hiring external consultants. ${ }^{674}$ That type of a requirement would go far in reducing the control of staff physicians on hospital staff decisions. It would force more autonomous decisionmaking by hospital administrators, yet it would preserve the quality assurance function performed by peer (but not competitive) physicians. Therefore, hospitals concerned about antitrust exposure could avoid liability by acting more like a firm and using outside professional consultants for quality assurance. The more hands-off approach advocated by Professor Havighurst will not be as likely to force what we (and HCQIA) deem to be a fundamental, salutary, procompetitive organizational change in the current peer-review process.

673. 42 U.S.C. $\S § 11112($ b)(3)(A)(ii), (iii) (Supp. 1988).

674. See Note, supra note 7 , at $1124 \mathrm{nn} .52-53$ and accompanying text. 